Prepared in cooperation with the U.S. Army Corps of Engineers

\title{
Modern (1992-2011) and Projected (2012-99) Peak Snowpack and May-July Runoff for the Fort Peck Lake and Lake Sakakawea Watersheds in the Upper Missouri River Basin
}

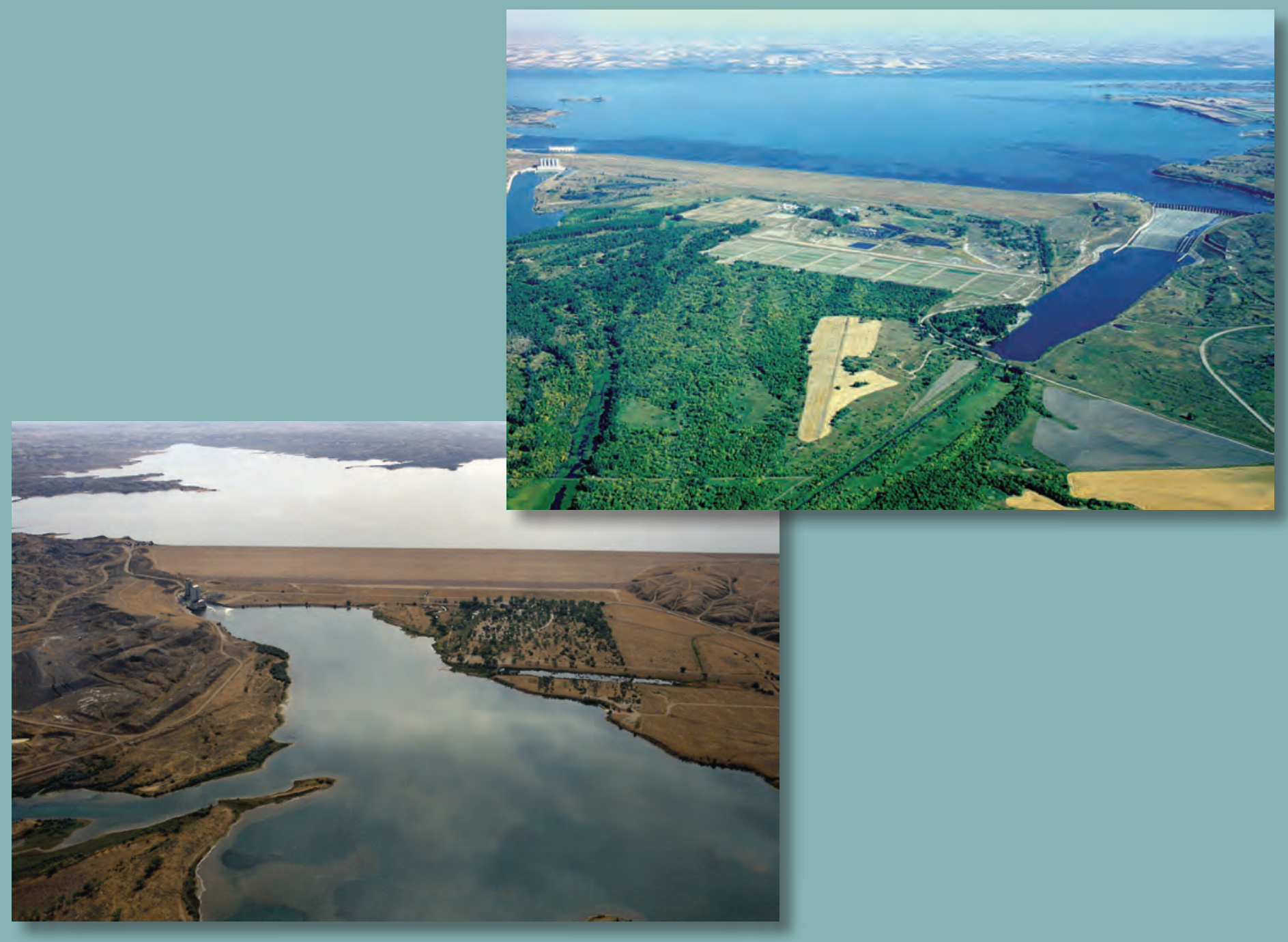

Scientific Investigations Report 2015-5135

Version 1.2, June 2016

U.S. Department of the Interior

U.S. Geological Survey 
Cover. Upper right photograph: View of the Garrison Dam and Lake Sakakawea. Lower left photograph: View of the Fort Peck Dam and Fort Peck Lake.

Photographs by Omaha District, U.S. Army Corps of Engineers. 


\section{Modern (1992-2011) and Projected (2012-99) Peak Snowpack and May-July Runoff for the Fort Peck Lake and Lake Sakakawea Watersheds in the Upper Missouri River Basin}

By John F. Stamm, Dennis Todey, Barbara Mayes Boustead, Shawn Rossi, Parker A. Norton, and Janet M. Carter

Prepared in cooperation with the U.S. Army Corps of Engineers

Scientific Investigations Report 2015-5135

Version 1.2, June 2016 


\title{
U.S. Department of the Interior SALLY JEWELL, Secretary
}

\section{U.S. Geological Survey Suzette M. Kimball, Director}

\author{
U.S. Geological Survey, Reston, Virginia: 2016 \\ First release: 2016 \\ Revised: June 2016 (ver 1.2)
}

For more information on the USGS - the Federal source for science about the Earth, its natural and living resources, natural hazards, and the environment—visit http://www.usgs.gov or call 1-888-ASK-USGS.

For an overview of USGS information products, including maps, imagery, and publications, visit http://www.usgs.gov/pubprod/.

Any use of trade, firm, or product names is for descriptive purposes only and does not imply endorsement by the U.S. Government.

Although this information product, for the most part, is in the public domain, it also may contain copyrighted materials as noted in the text. Permission to reproduce copyrighted items must be secured from the copyright owner.

Suggested citation:

Stamm, J.F.; Todey, Dennis; Mayes Boustead, Barbara; Rossi, Shawn; Norton, P.A.; and Carter, J.M., 2016, Modern (1992-2011) and projected (2012-99) peak snowpack and May-July runoff for the Fort Peck Lake and Lake Sakakawea watersheds in the Upper Missouri River Basin (ver. 1.2, June 2016): U.S. Geological Survey Scientific Investigations Report 2015-5135, 44 p., http://dx.doi.org/10.3133/sir20155135.

ISSN 2328-0328 (online 


\section{Contents}

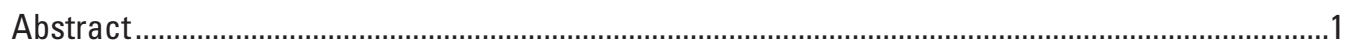

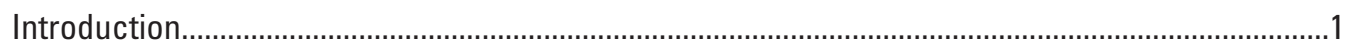

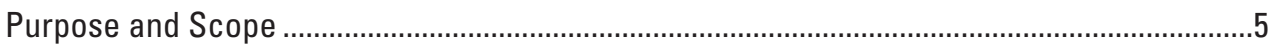

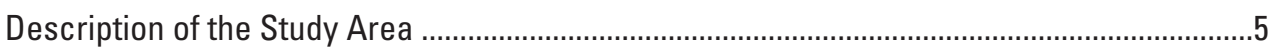

Climate of the Missouri River Basin and Lake Sakakawea Watershed ....................................

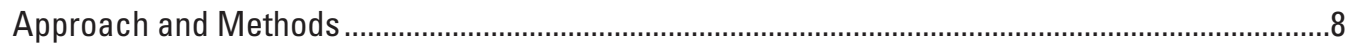

Historical Climatology Network and Snowpack Telemetry Station Data ...............................14

Community Climate System Model Output ............................................................................15

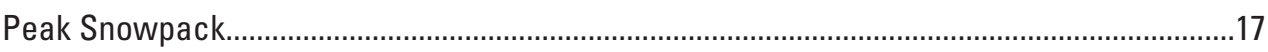

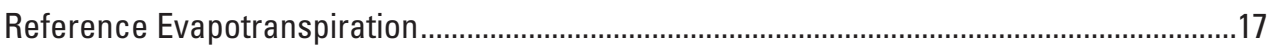

Modern (1992-2011) and Projected (2012-99) Peak Snowpack ......................................................18

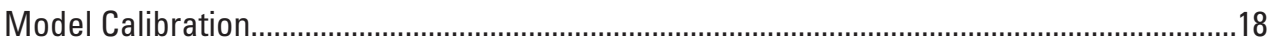

Modern (1992-2011) Peak Snowpack as Snow Water Equivalent ..........................................19

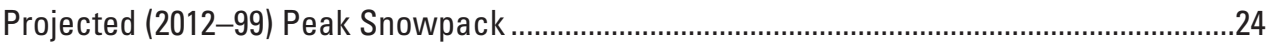

Modern (1992-2011) and Projected (2012-99) May-July Runoff..................................................24

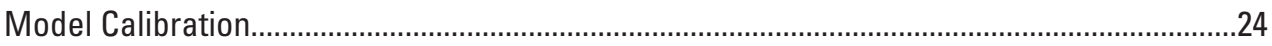

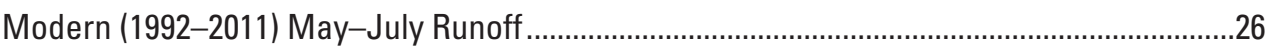

Projected (2012-99) May-July Runoff..............................................................................

Projected Power Production and Runoff Magnitudes ..........................................................35

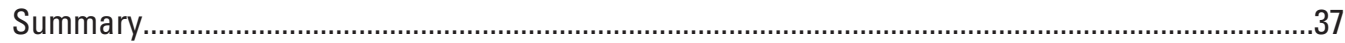

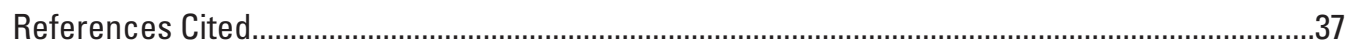

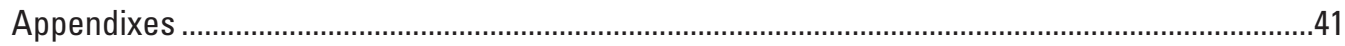

Appendix 1. Air Temperature and Precipitation at Stations ..................................................42

Appendix 2. Community Climate System Model Output ...........................................................42

Appendix 3: Interpolated Community Climate System Model Output ........................................43

Appendix 4: Bias-Corrected Community Climate System Model Output...................................4

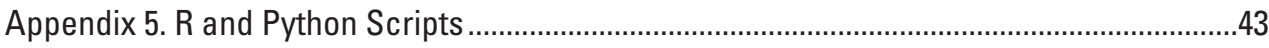

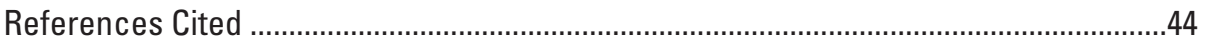

\section{Figures}

1. Map showing the Missouri River Basin and study area consisting of the drainage basins above Garrison and Fort Peck Dams. Associated watersheds are the Fort Peck Lake and Lake Sakakawea watersheds...

2. Graph showing gross power generation from the hydroelectric power plants at Fort Peck and Garrison Dams, 1968-2011.

3. Graph showing annual streamflow of the Missouri River at Bismarck, North Dakota (U.S. Geological Survey streamgage 06342500), showing years with annual flows greater than and less than median annual streamflow for water years 1954-2013.........4

4. Map showing location of the study area showing ecosystem regions, physical divisions, and U.S. Historical Climatology Network and snowpack telemetry stations used in analyses. 
5. Graph showing annual cycle of mean monthly air temperature and precipitation for 1981-2010 derived from the Parameter-elevation Regressions on Independent Slopes Model (PRISM), Lake Sakakawea watershed and Missouri River Basin

6. Graphs showing mean annual temperature and precipitations based on Parameter-elevation Regression on Independent Slopes Model (PRISM) output for 1981-2010

7. Map showing representation of topography by the Community Climate System Model, Version 3.0.

8. Graph showing incremental increase in multiple coefficient of determination $\left(R^{2}\right)$ values with addition of regressor variables in table 8.

9. Graph showing peak snowpack for runoff years 1992-2011 for the Fort Peck Lake watershed....

10. Graph showing peak snowpack as snow water equivalent for a runoff years 1992-2011 for the lower Lake Sakakawea watershed

11. Graph showing relation between regressed peak snowpack and observed peak snowpack at snowpack telemetry stations used for calibration, Fort Peck Lake and lower Lake Sakakawea watersheds

12. Graph showing relation between regressed peak snowpack and observed peak snowpack at snowpack telemetry stations used for validation, Fort Peck Lake and lower Lake Sakakawea watersheds

13. Graph showing projections of peak snowpack for runoff years 1992-2099 for the Fort Peck Lake watershed.

14. Graph showing projections of peak snowpack for runoff years 1992-2099 for the lower Lake Sakakawea watershed

15. Graph showing projected regressor variables for air temperature and precipitation for the plains elevation zone and mountains elevation zones for selected seasons......26

16. Graph showing incremental increase in multiple coefficient of determination $\left(R^{2}\right)$ values with addition of regressor variables in table 12

17. Graph showing May-July runoff for runoff years 1992-2011 for the Fort Peck Lake watershed

18. Graph showing May-July runoff for runoff years 1992-2011 for the lower Lake Sakakawea watershed

19. Graph showing May-July runoff for runoff years 1992-2011 for the Lake Sakakawea watershed (Fort Peck Lake and lower Lake Sakakawea watersheds combined)

20. Graph showing relation between regressed and observed May-July runoff used for calibration, Fort Peck Lake and lower Lake Sakakawea watersheds.

21. Graph showing relation between regressed and observed May-July runoff used for validation, Fort Peck Lake and lower Lake Sakakawea watersheds.

22. Graph showing projections of May-July runoff for runoff years 1992-2099 for the Fort Peck Lake watershed.

23. Graph showing projections of May-July runoff for runoff years 1992-2099 for the lower Lake Sakakawea watershed

24. Graph showing projections of May-July runoff for runoff years 1992-2099 for the Lake Sakakawea watershed (Fort Peck Lake and lower Lake Sakakawea watersheds combined) 
25. Graph showing April, May, June precipitation for the plains elevation zone and peak snowpack in the Fort Peck Lake watershed (Fort Peck Lake and lower Lake Sakakawea watersheds combined) as interpolated from Community Climate System Model, version 4.0 output.

26. Graph showing April, May, June precipitation for the plains elevation zone and peak snowpack in the lower Lake Sakakawea watershed as interpolated from Community Climate System Model, version 3.0 output

\section{Tables}

1. U.S. Historical Climate Network and snowpack telemetry stations used for analyses

2. Names and units of regressed and regressor variables for seasons and elevation zones as used in transfer functions.

3. Station numbers excluded to bootstrap air temperature and precipitation regressor variables used for calibration and validation...

4. Standard deviation of seasonal precipitation and air temperature for 1992-2011 from observations at Historical Climate Network and snow telemetry stations, and Community Climate System Model, version 3.0 and version 4.0.

5. Minimum value of seasonal precipitation and air temperature for 1992-2011 from observations at Historical Climate Network and snow telemetry stations, and Community Climate System Model, version 3.0 and version 4.0

6. Maximum value of seasonal precipitation and air temperature for 1992-2011 from observations at Historical Climate Network and snow telemetry stations, and Community Climate System Model, version 3.0 and version 4.0.

7. Station numbers excluded to bootstrap the regressed and regressor variables for peak snowpack

8. Coefficients of peak snowpack transfer functions for the Fort Peck Lake and lower Lake Sakakawea watersheds.

9. Results of paired Student's t-tests for the null hypothesis that observed and regressed peak snowpack have equal means

10. Summary statistics for observed and regressed peak snowpack for runoff years 1992-2011

11. Mean number of years within a 10-year moving window, rounded off to the nearest integer, for which regressor variables representing air temperature and precipitation were outside of the range used for calibration of transfer functions........27

12. Coefficients of May-July runoff transfer functions for the Fort Peck Lake and lower Lake Sakakawea watersheds.

13. Results of Student's t-tests for the null hypothesis that observed and regressed May-July runoff have equal means...

14. Summary statistics for observed and regressed May-July runoff for runoff years 1992-2011 


\section{Conversion Factors}

Inch/Pound to International System of Units

\begin{tabular}{lcl}
\hline \multicolumn{1}{c}{ Multiply } & By & \multicolumn{1}{c}{ To obtain } \\
\hline inch (in.) & Length & \\
foot (ft) & 25.4 & millimeter $(\mathrm{mm})$ \\
mile (mi) & 0.3048 & meter $(\mathrm{m})$ \\
& 1.609 & kilometer $(\mathrm{km})$ \\
\hline acre & Area & \\
square mile $\left(\mathrm{mi}^{2}\right)$ & 4,047 & square meter $\left(\mathrm{m}^{2}\right)$ \\
\hline & 2.590 & square kilometer $\left(\mathrm{km}^{2}\right)$ \\
\hline acre-foot (acre-ft) & Volume & \\
\hline & 1,233 & cubic meter $\left(\mathrm{m}^{3}\right)$ \\
\hline cubic foot per second $\left(\mathrm{ft}^{3} / \mathrm{s}\right)$ & Flow rate & \\
inch per day (in $/ \mathrm{d})$ & 0.02832 & cubic meter per second $\left(\mathrm{m}^{3} / \mathrm{s}\right)$ \\
seconds per foot & 25.4 & millimeter per day $(\mathrm{mm} / \mathrm{d})$ \\
\hline & 0.3048 & seconds per meter \\
\hline megawatt hour $(\mathrm{MWh})$ & Energy & \\
watt per meter squared $\left(\mathrm{W} / \mathrm{m}^{2}\right)$ & $3,600,000,000$ & joule $(\mathrm{J})$ \\
& 0.3172 & British thermal unit $(\mathrm{Btu})$ per \\
& & hour per square foot \\
\hline
\end{tabular}

Temperature in degrees Fahrenheit $\left({ }^{\circ} \mathrm{F}\right)$ may be converted to degrees Celsius $\left({ }^{\circ} \mathrm{C}\right)$ as follows:

${ }^{\circ} \mathrm{C}=\left({ }^{\circ} \mathrm{F}-32\right) / 1.8$

\section{Datum}

Vertical coordinate information is referenced to the North American Vertical Datum of 1988 (NAVD 88).

Horizontal coordinate information is referenced to the North American Datum of 1983 (NAD 83). Elevation, as used in this report, refers to distance above the vertical datum.

\section{Supplemental Information}

A runoff year is defined as the period July-June (begins July 1 and ends June 30 of specified year). 


\title{
Abbreviations
}

\author{
AIC Akaike's Information Criterion \\ AMJ April, May, June \\ AOGCM Atmosphere-Ocean General Circulation Model \\ CCSM Community Climate System Model \\ CCSM3 Community Climate System Model, version 3.0 \\ CCSM4 Community Climate System Model, version 4.0 \\ HCN U.S. Historical Climatology Network \\ JAS July, August, September \\ JFM January, February, March \\ OND October, November, December \\ PRISM Parameter-elevation Regressions on Independent Slopes Model \\ RCP 8.5 representative concentration pathway of 8.5 watts per meter squared \\ SNOTEL snowpack telemetry \\ SWE snow water equivalent \\ USGS U.S. Geological Survey
}





\title{
Modern (1992-2011) and Projected (2012-99) Peak Snowpack and May-July Runoff for the Fort Peck Lake and Lake Sakakawea Watersheds in the Upper Missouri River Basin
}

\author{
By John F. Stamm, ${ }^{1}$ Dennis Todey, ${ }^{2}$ Barbara Mayes Boustead, ${ }^{3}$ Shawn Rossi, ${ }^{3}$ Parker A. Norton, ${ }^{1}$ and \\ Janet M. Carter ${ }^{1}$
}

\section{Abstract}

Mountain snowpack is an important contributor to runoff in the Upper Missouri River Basin; for example, high amounts of winter and spring precipitation in the mountains and plains in 2010-11 were associated with the peak runoff of record in 2011 in the Upper Missouri River Basin. To project trends in peak mountain snowpack and runoff in the upcoming decades, multiple linear regression models of peak mountain snowpack and total May-July runoff were developed for the Fort Peck Lake (above Fort Peck Dam) and lower Lake Sakakawea watersheds (between Fort Peck and Garrison Dams) in the Upper Missouri River Basin. Input to regression models included seasonal estimates of precipitation, air temperature, and total reference evapotranspiration stratified by elevation. Calibration was based on records from 107 weather stations from 1991 to 2011. Regressed annual peak mountain snowpack was used as input to the transfer function of May-July runoff. Peak snowpack and May-July runoff were projected for 2012-99 on the basis of air temperature and precipitation from the Community Climate System Model (CCSM) output. Two estimates of projected peak snowpack and May-July runoff for 2012-99 were computed: one estimate was based on output from the CCSM, version 3.0 (CCSM3), and the second estimate was based on output from the CCSM, version 4.0 (CCSM4). The significance of projected trends was based on the Kendall's tau nonparametric test.

Annual peak snowpack was projected to have a downward trend for the Fort Peck Lake watershed and no trend for the lower Lake Sakakawea watershed. Projections of May-July runoff had a significant downward trend for the Fort Peck Lake, lower Lake Sakakawea, and Lake Sakakawea (combination of Fort Peck Lake and lower Lake Sakakawea)

${ }^{1}$ U.S. Geological Survey.

${ }^{2}$ South Dakota State University

${ }^{3}$ National Weather Service. watersheds. Downward trends in projected May-July runoff indicated that power production at Fort Peck Dam might be affected particularly in the later part of the simulation (2061-99); however, confidence in projected May-July runoff for the later part of the simulation was less certain because bias-corrected air temperatures from CCSM3 and CCSM4 commonly fell outside of the observed range used for calibration. Projected May-July runoff combined for the Fort Peck Lake and lower Lake Sakakawea watersheds were on the order of magnitude of the 2011 flood for 1 simulation year for each of the CCSM-based simulations. High peak snowpack and precipitation in April, May, and June in the plains was associated with large May-July runoff events; therefore, high precipitation at lower elevations in the Fort Peck Lake and lower Lake Sakakawea watersheds was a factor in the simulation of extreme runoff events at the magnitude of the 2011 flood.

\section{Introduction}

The Missouri River is the longest river in the United States, and the Missouri River Basin is the second largest drainage basin in the United States (Kammerer, 1990). From its headwaters in western Montana, the Missouri River flows about 2,300 miles (mi) to its confluence with the Mississippi River (fig. 1). The drainage area of the Missouri River of 529,000 square miles $\left(\mathrm{mi}^{2}\right)$ accounts for nearly one-half the drainage area of the Mississippi River Basin (Kammerer, 1990). Six dams and reservoirs are along the main stem of the Missouri River and compose the Missouri River reservoir system: Fort Peck Dam forming Fort Peck Lake (Montana), Garrison Dam forming Lake Sakakawea (North Dakota), Oahe Dam forming Lake Oahe (South Dakota), Big Bend Dam forming Lake Sharpe (South Dakota), Fort Randall Dam forming Lake Francis Case (South Dakota), and Gavins Point Dam forming Lewis and Clark Lake (South Dakota and Nebraska). 
The Missouri River Basin above Gavins Point Dam is referred to as the Upper Missouri River Basin (fig. 1).

The combined storage capacity of the six main-stem dams, 72.4 million acre-feet (acre-ft), makes the Missouri River reservoir system the largest in North America (U.S. Army Corps of Engineers, 2013a). The Missouri River reservoir system is regulated to serve the eight congressionally authorized purposes of flood control, water supply, water-quality control, navigation, hydroelectric power generation, irrigation, recreation, and fish and wildlife (including threatened and endangered species). During 1968-2011, mean annual gross power production was 1,047,594 and 2,253,338 megawatt hours (MWh) for the hydroelectric power plants of Fort Peck and Garrison Dams, respectively (fig. 2). Maximum annual gross power generation was 1,662,509 MWh (in 1976) and 3,350,271 MWh (in 1975) for the Fort Peck and Garrison Dams, respectively, for 1968-2011. Mean annual inflow to Fort Peck Lake and Lake Sakakawea for 1968-2011 was 10,200 and 23,000 cubic feet per second $\left(\mathrm{ft}^{3} / \mathrm{s}\right)$, respectively (U.S. Army Corps of Engineers, 2015).

The U.S. Army Corps of Engineers (2006, revised plate A-3) identified three periods of drought since 1954 on the basis of annual runoff at Sioux City, Iowa: 1954-61, 1987-92, and 2000-5. Drought was defined as years when less than median runoff occurred for more than 3 consecutive calendar years. Annual streamflow of the Missouri River at the U.S. Geological Survey (USGS) streamgage at Bismarck, North Dakota (streamgage 06342500; fig. 3), about $65 \mathrm{mi}$ downstream from Garrison Dam (fig. 1), was below the median annual streamflow for 1954-2013 of 21,490 $\mathrm{ft}^{3} / \mathrm{s}$ for water years 1955-64, 1987-95, 2001-10, and 2013 (U.S. Geological Survey, 2014). A water year begins October 1 and ends September 30, and is designated by the calendar year in which the water year ends. The 2011 runoff was the highest annual streamflow of record at the Bismarck, N. Dak., streamgage (fig. 3) and for much of the Missouri River (National Oceanic and Atmospheric Administration, 2012). Recent variability in climate is expressed by the change from conditions that produced the flood of 2011 to the "flash" drought of 2012 (Hoerling and others, 2013). A flash drought is defined as having a sudden onset and having identified effects on agriculture, fire potential, livestock health, and other effects (Svoboda and others, 2002). Annual streamflow changed from 53,210 $\mathrm{ft}^{3} / \mathrm{s}$ in water year 2011 to $25,010 \mathrm{ft}^{3} / \mathrm{s}$ in water year 2012 .

The flood of 2011 was associated with exceptional thickness of snowpack and high precipitation that fell December 2010 through April 2011. Vining and others (2013) described the climatology of this event, which is summarized herein. Snow water equivalent (SWE) in the Rocky Mountains of Montana and Wyoming was 111 to more than 150 percent of the mean SWE at snowpack telemetry (SNOTEL) sites operated by the U.S. Department of Agriculture Natural Resources Conservation Service (Natural Resources Conservation Service, 2014). Above normal precipitation for December 2010 through May 2011 was also recorded at weather stations in the
Great Plains of Montana, North Dakota, and South Dakota. May 2011 precipitation was exceptionally high, and rainfall amounts in Montana nearly were equal to normal annual total rainfall.

The flood of 2011 and flash drought of 2012 might be hypothesized as natural variability within an assumed stationary climate or extremes reflecting a changing and nonstationary climate. Stationarity is the concept that natural systems fluctuate within a fixed window of variability for a given period (Milly and others, 2008). Stationarity in natural systems has been compromised by human disturbances and should no longer be assumed by water resource managers (Milly and others, 2008). Indicators of nonstationarity in characteristics of streamflow have been identified for drainage basins within the Missouri River Basin (Hirsch, 2011; Hirsch and Ryberg, 2011; Norton and others, 2014).

The need for adaptive management strategies in response to climate variability and projected climate change prompted the U.S. Army Corps of Engineers and Bureau of Reclamation to establish pilot studies to address several targeted research questions. One such research question posed (U.S. Army Corps of Engineers, 2012, p. 2) was, "Is mountain snowpack and subsequent runoff changing due to changes in climate, and is the Missouri River Basin, therefore, more susceptible to droughts and floods?" This research question was posed to address issues of projected climate change for long-term planning and management (Brekke and others, 2011). Herein, the term "projected" will be used instead of "future" to reflect that there are many possible future trajectories in climate and societal response, a few of which are selected for simulation by global climate models (Nakićenović and Swart, 2000; Vuuren and others, 2011). The U.S. Army Corps of Engineers and Bureau of Reclamation identified several technical steps required for long-term planning and management. The three technical steps of greatest concern were the following:

1. Make decisions on how to use climate change information,

2. Assess natural system responses, and

3. Communicate results and uncertainties to decision makers.

The U.S. Army Corps of Engineers completed a pilot research study (Grode and others, 2014) in collaboration with the USGS, National Weather Service, U.S. Department of Agriculture Natural Resources Conservation Service, and South Dakota State University to help address the aforementioned research question. Additional assistance was needed to address the research question that was posed, and to address the technical steps in the context of climate variability, projected climate, and responses of mountain snowpack and associated runoff. As a result, the U.S. Geological Survey, in cooperation with the Climate Preparedness and Resilience Community of Practice of the U.S. Army Corps of Engineers, completed a followup study to simulate modern (1992-2011) and projected (2012-99) mountain peak snowpack and 


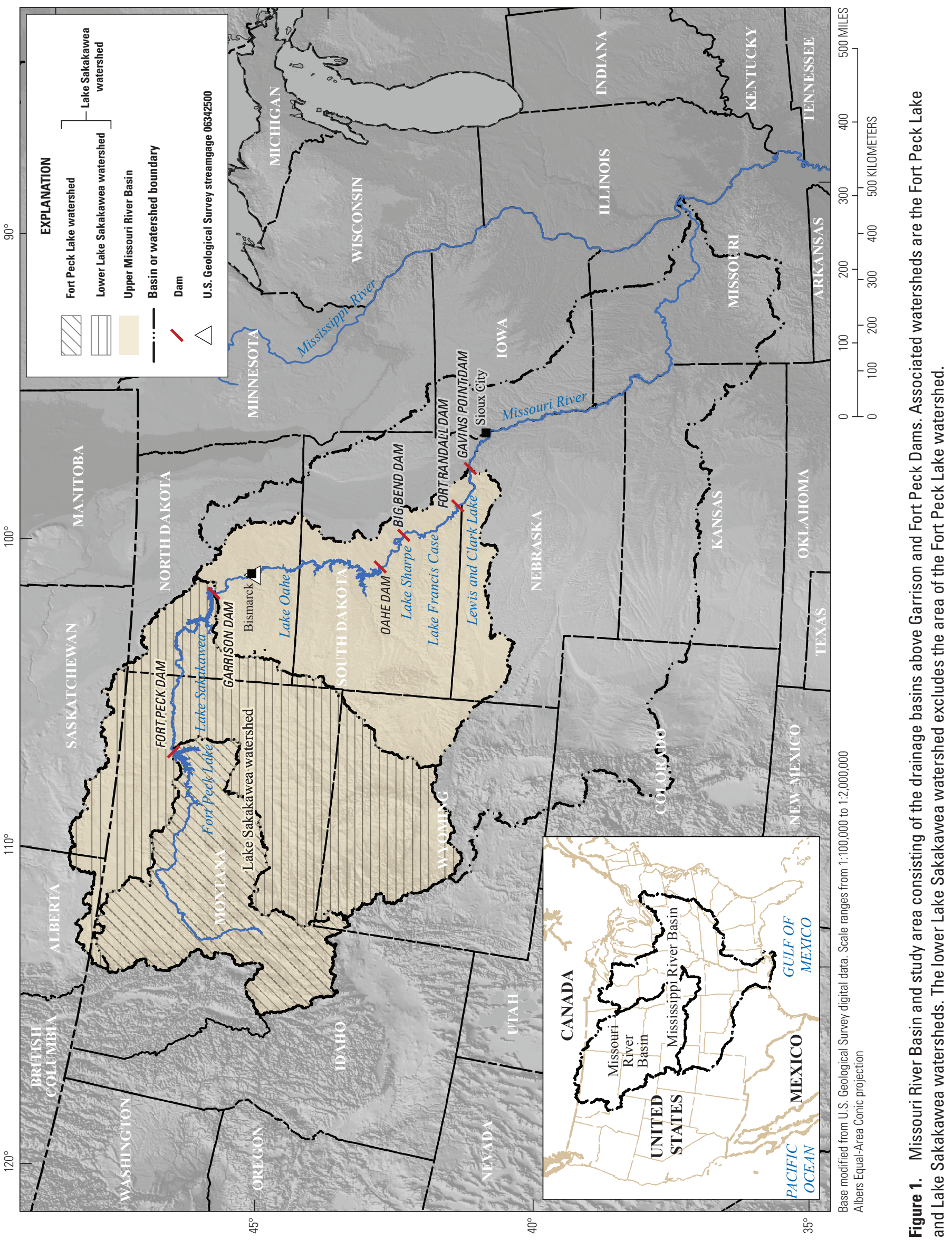




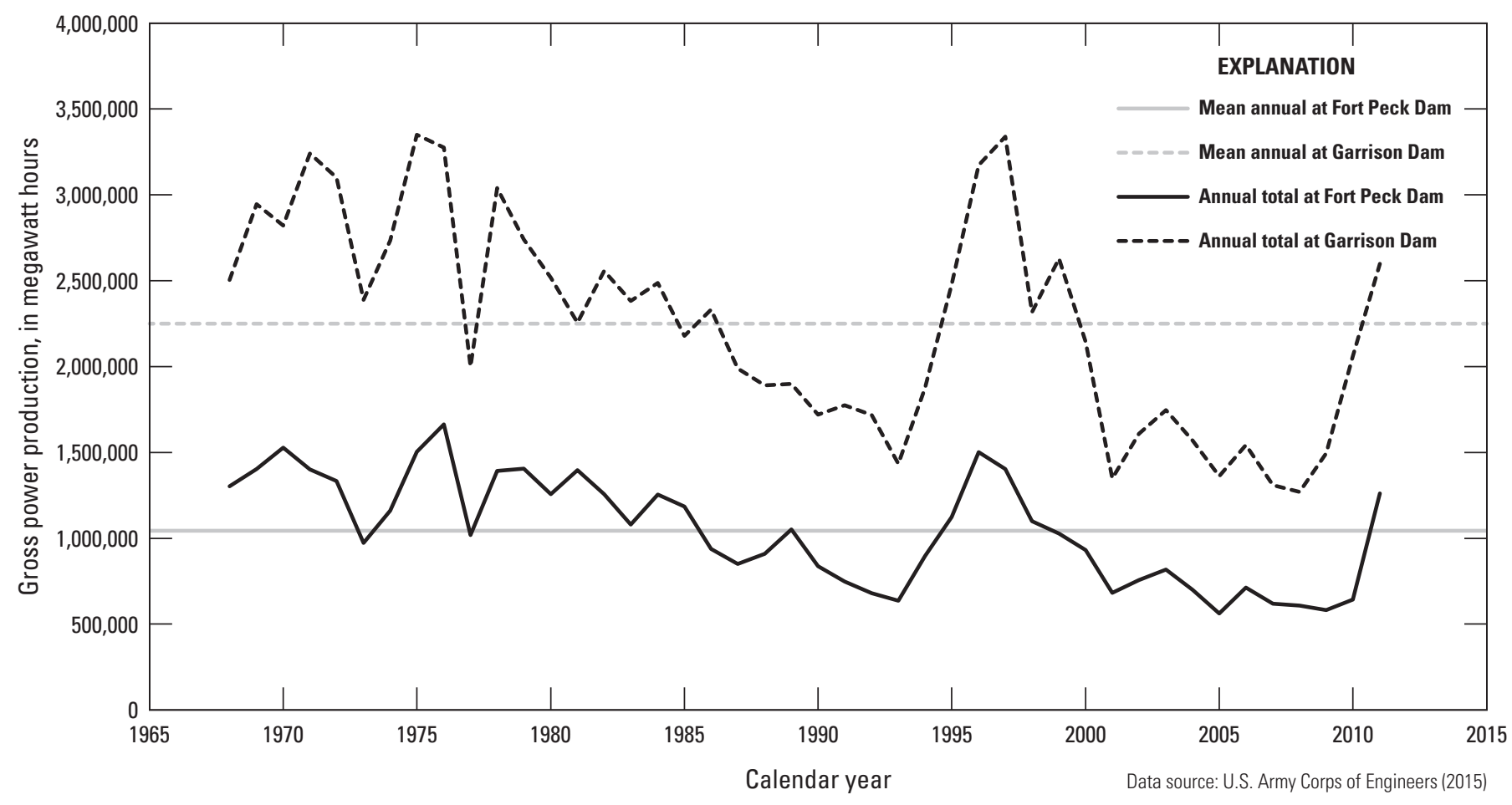

Figure 2. Gross power generation from the hydroelectric power plants at Fort Peck and Garrison Dams, 1968-2011.

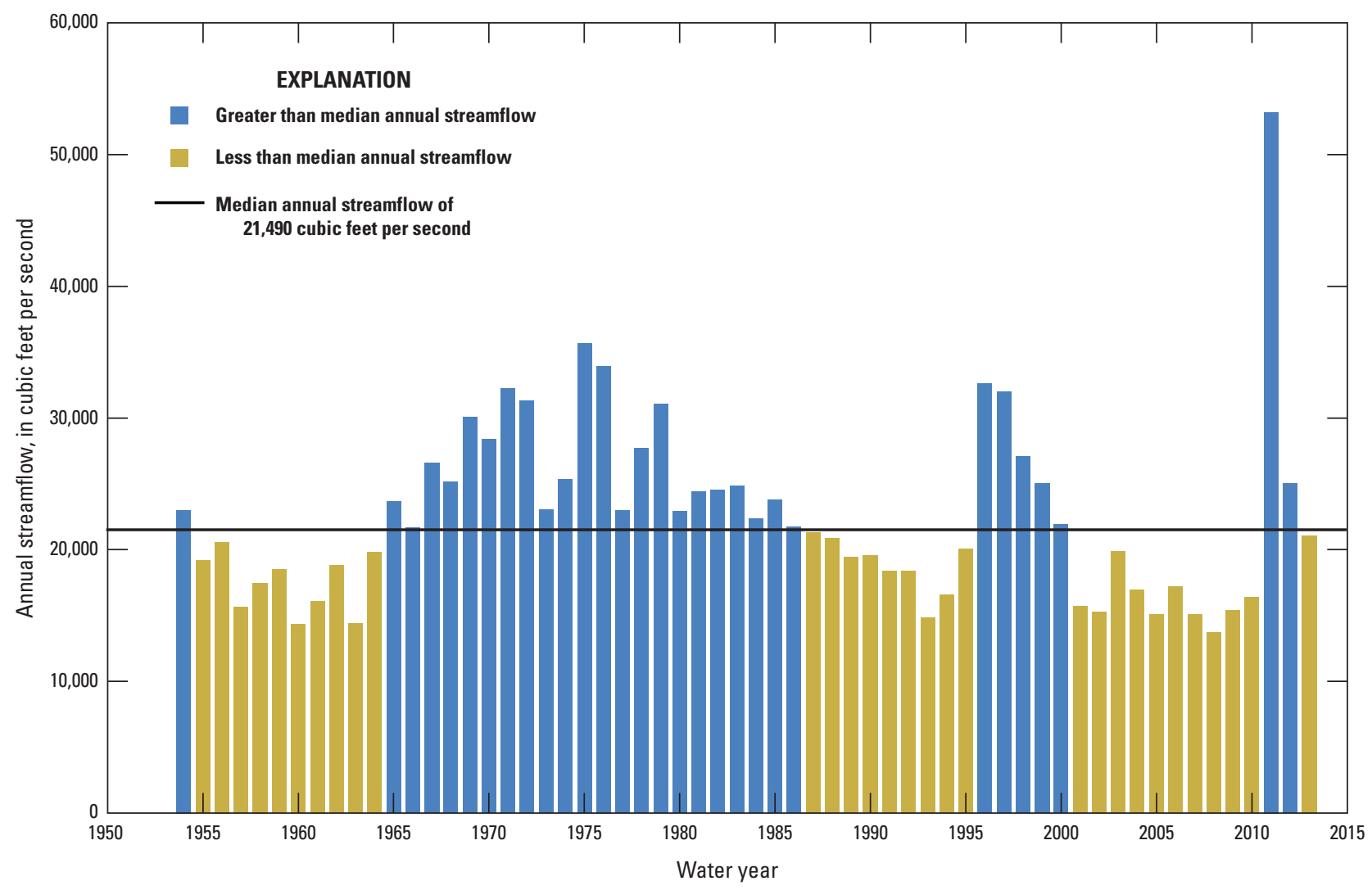

Figure 3. Annual streamflow of the Missouri River at Bismarck, North Dakota (U.S. Geological Survey streamgage 06342500), showing years with annual flows greater than and less than median annual streamflow for water years 1954-2013. Streamflow data from U.S. Geological Survey (2014). 
May-July runoff into Fort Peck Lake and Lake Sakakawea in the upper part of the Missouri River Basin. Additional objectives of this study were to determine if May-July runoff as projected for 2012-99 might produce runoff events on the magnitude of the 2011 flood, develop insights to processes associated with such events, and determine if projected May-July runoff might drop below the magnitude required to maintain power generation at hydroelectric dams.

\section{Purpose and Scope}

The purpose of this report is to present results of simulations of modern (1992-2011) and projected (2012-99) peak snowpack and May-July runoff into Fort Peck Lake and Lake Sakakawea. Peak mountain snowpack is the maximum height of snow recorded at selected stations in the Rocky Mountains in a given year, and is hereafter referred to as "peak snowpack." Peak snowpack is reported as SWE, which is defined as the height of water produced by melting a column of snow with potentially varying snow density and possibly containing water retained by capillary forces (Garstka, 1964, p. 10-6). In the Upper Missouri River Basin, much of the May-July runoff is derived from the melting of snowpack, and generally during this time almost one-half of the total annual runoff is conveyed through the Missouri River reservoir system (U.S. Army Corps of Engineers, 2006). Herein, runoff is reported as total volume in thousand acre-feet for May-July. This report also describes projected May-July runoff to 2099 in relation to the magnitude of the 2011 flood and magnitudes required to maintain power generation at hydroelectric dams.

\section{Description of the Study Area}

The study area is the Lake Sakakawea watershed, which is located in the northern part of the Upper Missouri River Basin (figs. 1 and 4). The Fort Peck Lake watershed is located along the Missouri River within the headwaters of the Lake Sakakawea watershed. The part of the Lake Sakakawea watershed that does not include the Fort Peck Lake watershed is hereinafter referred to as the "lower Lake Sakakawea watershed;" therefore, runoff from the Lake Sakakawea watershed is the product of runoff from the Fort Peck Lake and lower Lake Sakakawea watersheds. The drainage areas of the Fort Peck Lake and lower Lake Sakakawea watersheds are 57,500 and $123,900 \mathrm{mi}^{2}$, respectively, with a combined area for the Lake Sakakawea watershed of 181,400 $\mathrm{mi}^{2}$ (U.S. Army Corps of Engineers, 2013b). The lower Lake Sakakawea watershed includes the drainage area of the Yellowstone River (fig. 4). The headwaters of the Yellowstone River and the Fort Peck Lake watershed are part of the high elevations of the Rocky Mountains physical division, hereinafter referred to as the "Rocky Mountains" (Fenneman, 1931). About 36,020 mi (62 percent) of the Fort Peck Lake watershed and 93,345 $\mathrm{mi}^{2}$ (75 percent) of the lower Lake Sakakawea watershed lies within the Great Plains ecoregion and physical division, hereinafter referred to as the "Great Plains" (Fenneman, 1931) (fig. 4).

\section{Climate of the Missouri River Basin and Lake Sakakawea Watershed}

The climate of the Missouri River Basin, based on a first order Köppen classification (Peel and others, 2007), can be described as arid and cold in the west, cold in the northeast, and temperate to the south. The climate of the Missouri River Basin was described by the U.S. Army Corps of Engineers (2006) as having large variability in air temperature and precipitation produced by the interaction of air masses from the Gulf of Mexico, Pacific Ocean, and polar air masses from Canada (fig. 1). Air masses from the Gulf of Mexico affect summer weather, and air masses from the Pacific Ocean and Canada affect winter weather. Precipitation in the Missouri River Basin is a result of cyclonic fronts in winter and thunderstorms in the summer (U.S. Army Corps of Engineers, 2006).

The climate of the Missouri River Basin and the Lake Sakakawea watershed can be described on the basis of the Parameter-elevation Regressions on Independent Slopes Model (PRISM; Daly and others, 1994, 2002). The PRISM interpolates weather station observations of monthly total precipitation and monthly means of minimum and maximum daily air temperature to a 2.5 arc-minute grid for the conterminous United States. The PRISM output corresponding to the 1981-2010 climate normal (a climate normal is a 30-year period) is described herein. For the Missouri River Basin and the Lake Sakakawea watershed, precipitation falls mostly in May-July (fig. 5) during which thunderstorms are common (U.S. Army Corps of Engineers, 2006). The combination of high precipitation and high minimum and maximum air temperature during these months (fig. 5) results in high amounts of runoff directly from precipitation and derived from snowmelt; therefore climate, mountain snowpack, and runoff for these months were the focus of this study. Monthly precipitation for the Lake Sakakawea watershed has a slightly bimodal distribution with one peak for May-July and a second smaller peak for September (fig. 5). Annual precipitation has an east-west gradient with the least amount of annual precipitation in the western part of the Missouri River Basin and the greatest amount of annual precipitation in the eastern part (fig. 6); however, there also is an elevation gradient such that the Rocky Mountains have higher annual precipitation than the adjacent Great Plains (fig. 4). The largest spatial gradient in annual precipitation is in the vicinity of the 100th meridian of longitude. Mean annual daily maximum air temperature is generally warmest in the southern part and coolest in the western part of the Missouri River Basin (fig. 6) such as in the headwater areas of the Lake Sakakawea watershed. Mean annual daily minimum air temperature roughly follows a north-south gradient with the warmest air temperatures in the southern part of the Missouri River Basin (fig. 6). 


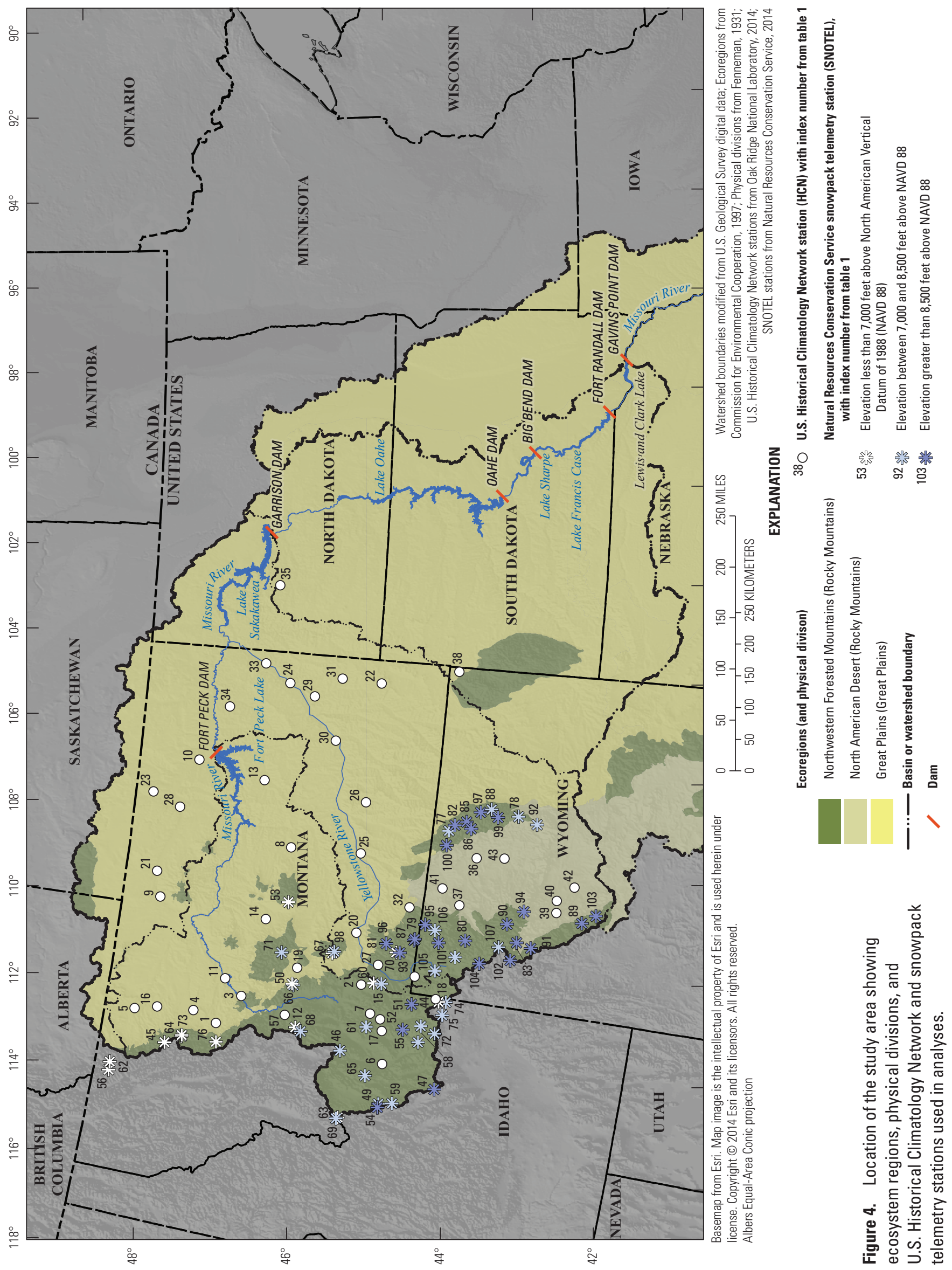



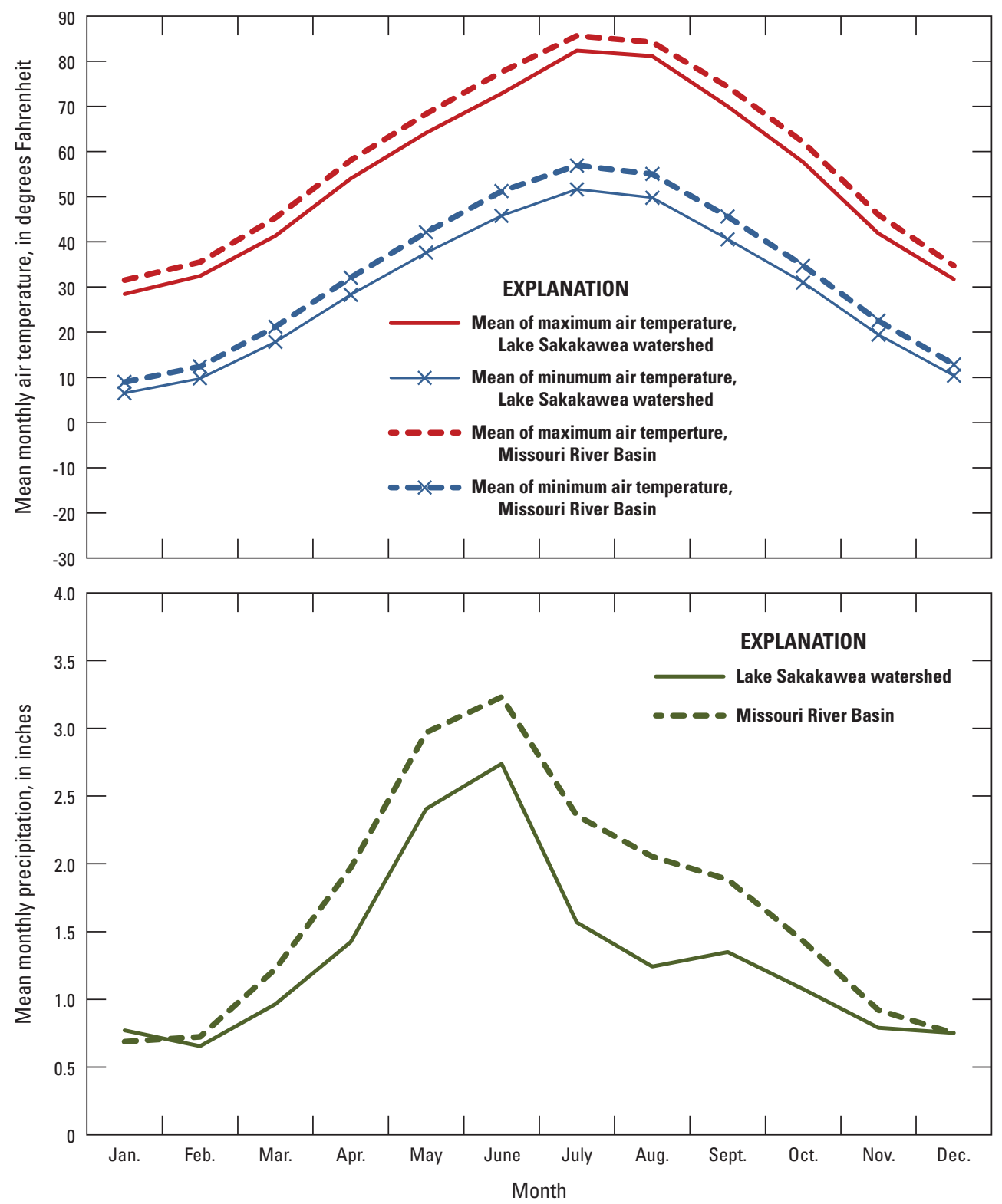

Figure 5. Annual cycle of mean monthly air temperature and precipitation for 1981-2010 derived from the Parameter-elevation Regressions on Independent Slopes Model (PRISM; Daly and others, 1994, 2002), Lake Sakakawea watershed and Missouri River Basin. 
A. Mean annual daily minimum air temperature

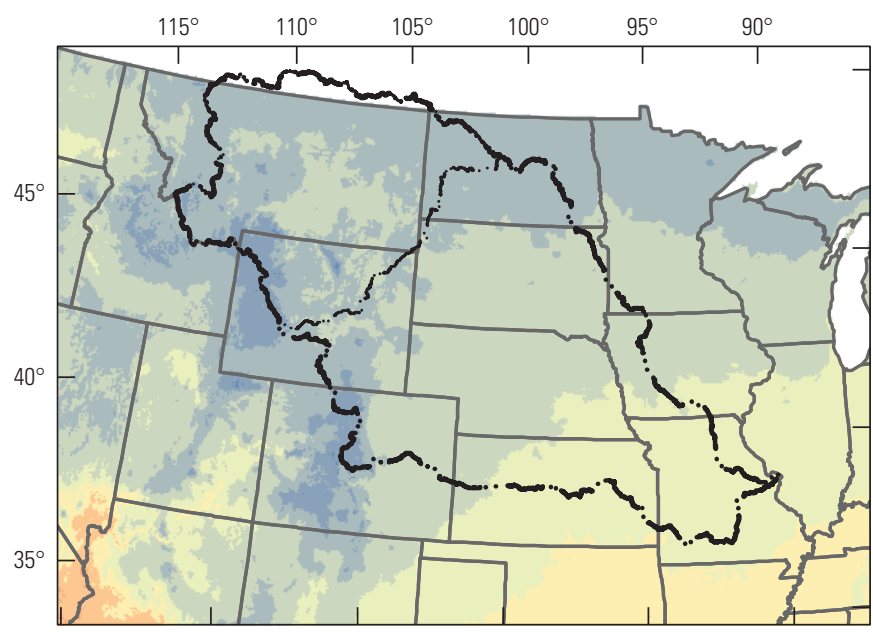

\section{Mean annual total precipitation}

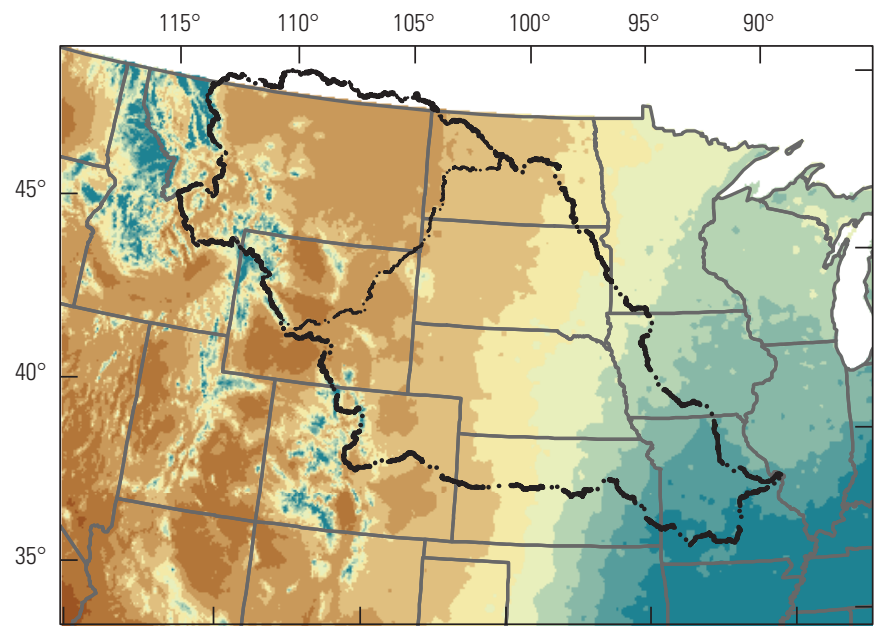

Mean annual precipitation and air temperature computed from the Parameter-elevation Regressions on Independent Slopes Model [(PRISM), Daly and others, 1994, 2002], 1981-2010
B. Mean annual daily maximum air temperature

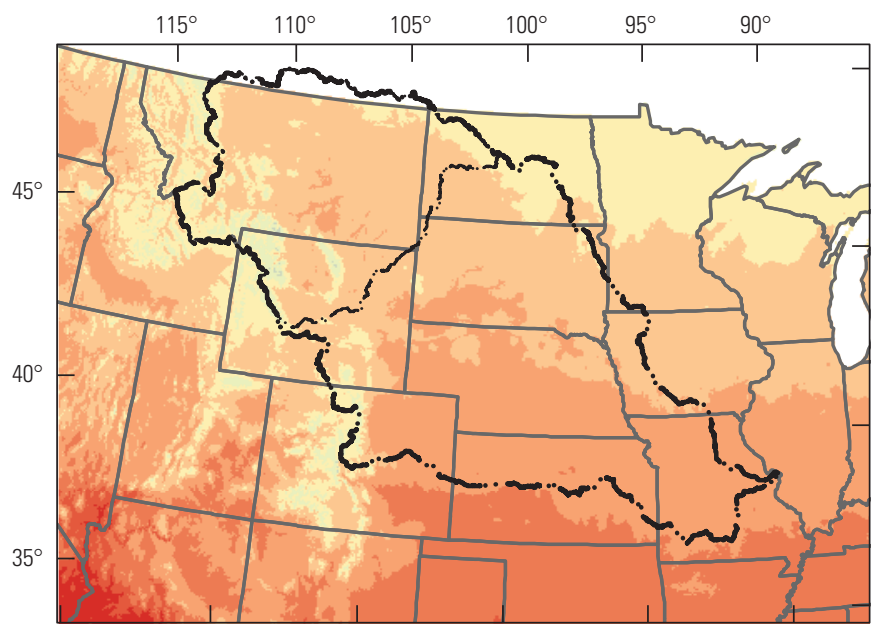

\section{EXPLANATION}

Mean annual precipitation, in inches

Less than 5

5 to less than 10

10 to less than 15

15 to less than 20

20 to less than 25

25 to less than 30

30 to less than 35

35 to less than 40

40 to less than 45

45 or greater
Mean air temperature, in degrees Fahrenheit

Less than 20

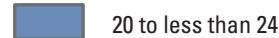

24 to less than 28

28 to less than 32

32 to less than 36

36 to less than 40

40 to less than 44

44 to less than 48

48 to less than 52

52 to less than 56

56 to less than 60

60 or greater

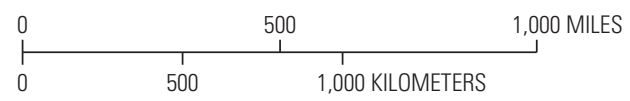

Figure 6. Mean annual temperature and precipitations based on Parameter-elevation Regression on Independent Slopes Model (PRISM) output for 1981-2010. $A$, mean annual daily minimum air temperature; $B$, mean annual daily maximum air temperature; and, $C$, mean annual total precipitation.

\section{Approach and Methods}

Modern (1992-2011) and projected (2012-99) peak snowpack and May-July runoff were estimated using transfer functions calibrated on the basis of seasonal means of mean air temperature and total precipitation recorded at the location of U.S. Historical Climatology Network (HCN) stations and Natural Resources Conservation Service SNOTEL stations. The use of the term "transfer function" was taken from paleoclimate research (Bradley, 1999) and implies a strong relation between "regressed" (dependent) variables and "regressor" (explanatory) variables [terminology as described by Davis (2002)], which might be considered a "proxy" of the regressed variable; for example, in paleoclimate applications tree-ring widths are proxies for annual or seasonal precipitation. Herein, the regressor variable precipitation might be considered a proxy for snowpack. Projected peak snowpack and May-July runoff to 2099 were computed on the basis of applying transfer functions to the output from two versions (3.0 and 4.0) of the Community Climate System Model (CCSM), which is an Atmosphere-Ocean General Circulation Model (AOGCM) of 
global climate. This research was funded as a pilot study and as such was not an exhaustive evaluation of projected climate scenarios based on ensembles of AOGCM output.

The transfer functions were multiple linear regression models in which a regressed variable was estimated using a set of regressor variables; for example, in a simple linear model:

$$
Y=a_{0}+a_{1} X_{1}+a_{2} X_{2}
$$

where

$\begin{aligned} Y & \text { is the regressed (dependent) variable, } \\ a_{0} & \text { is the intercept, } \\ a_{1} \text { and } a_{2} & \text { are coefficients, and } \\ X_{1} \text { and } X_{2} & \text { are the regressor (explanatory) variables. }\end{aligned}$

Peak snowpack and May-July runoff were regressed variables. Regressor variables used to regress peak snowpack included seasonal means of mean air temperature and total precipitation. The transfer function for May-July runoff included these same regressor variables plus peak snowpack and seasonal total reference evapotranspiration. Regressed and regressor variables for the calibration period, 1992-2011, were computed on the basis of HCN and SNOTEL station records of monthly air temperature and precipitation. The HCN and SNOTEL stations used are listed in table 1, and locations are shown in figure 4. Regressor variables for the projection period (2012-99) were computed from downscaled CCSM output of monthly air temperature and precipitation interpolated to the location of HCN and SNOTEL stations. Separate transfer functions of peak snowpack and May-July runoff were calibrated and validated for the Fort Peck Lake and lower Lake Sakakawea watersheds.

Several regressor variables were computed by stratifying HCN and SNOTEL station records of air temperature and precipitation by watershed, season, and elevation. Stratification by watershed was by extraction of stations within the Fort Peck and lower Lake Sakakawea watersheds. Stratification by elevation was by further extracting stations by three elevation zones:

- plains, less than 7,000 feet (ft);

- foothills, from 7,000 to $8,000 \mathrm{ft}$; and

- mountains, greater than $8,500 \mathrm{ft}$.

These terms are not meant to imply physiographic setting of individual stations; for example, a station assigned to the plains elevation zone may not necessarily be in the Great Plains, and could be located in a mountain valley. All elevations described hereinafter are in units of feet above the North American Vertical Datum of 1988 (NAVD 88). Stratification by seasons were relative to a 12-month period ending within the runoff season (May-July) and were defined as: July, August, September (JAS); October, November, December (OND); January, February, March (JFM); and April, May, June (AMJ). Note that JAS and OND were taken from the calendar year preceding JFM and AMJ. The seasons JAS, OND, JFM, and AMJ are herein collectively (July-June) referred to as a "runoff year," which is referred to by the calendar year for JFM and AMJ; thus, runoff year 1992 begins July 1, 1991, and ends June 30, 1992. Stratified by watershed, elevation, and season, the HCN and SNOTEL station records were then averaged to compute regressor variables. The regressor variables for the peak snowpack transfer function were the following:

- Watershed spatial average of the seasonal means of daily mean air temperature for each elevation zone (12 variables for each watershed), and

- Watershed spatial average of seasonal mean of total precipitation for each elevation zone (12 variables for each watershed).

The peak snowpack transfer function for each watershed could, therefore, include as much as 24 regressor variables. Names of regressor variables used in scripts and data files are listed in table 2.

Bootstrap methods (Efron, 1979) were used to compute regressor variables for calibration and validation of transfer functions. The bootstrap method increases the number of records available for calibration by iteratively removing $\mathrm{HCN}$ and SNOTEL stations and recomputing regressor variables for each year using the remaining stations. The $\mathrm{HCN}$ and SNOTEL stations removed with each bootstrap iteration are listed in table 3. Regressor variables were bootstrapped four times, which resulted in an additional 80 records (20 years, bootstrapped four times) and a total of 100 records for calibration and validation; that is, the 100 records include 20 records computed using all stations and an additional 80 records bootstrapped by iteratively removing stations. A total of 5 records were randomly selected from the 100 records for validation. The remaining 95 records were used for calibration of the transfer function.

Stepwise regression was used to reduce the number of regressor variables in a model. Stepwise regression iteratively includes regressor variables and evaluates the model's improvement with each step using the Akaike's Information Criterion (AIC) (Akaike, 1974; Adler, 2010). Draper and Smith (1981) suggest caution when relying on automated methods such as stepwise techniques to develop multiple linear regression models. Therefore, three measures were considered in evaluating improvement in the model: the AIC; the incremental increase in the multiple $R^{2}$ (coefficient of determination [Ott, 1993]) with the addition of a regressor variable; and effects that addition of a new regressor variable had on the coefficient of regressor variables already in the multivariate model. The R statistical program, version 3.0.2 (described by Adler, 2010), was the statistical analysis package used in this study.

The transfer function for May-July runoff included additional regressor variables to those previously described. Additional variables for each watershed included total reference evapotranspiration, stratified by season and elevation zone (plains, foothills, mountains) for an additional 12 regressor variables, and peak snowpack as one additional regressor 


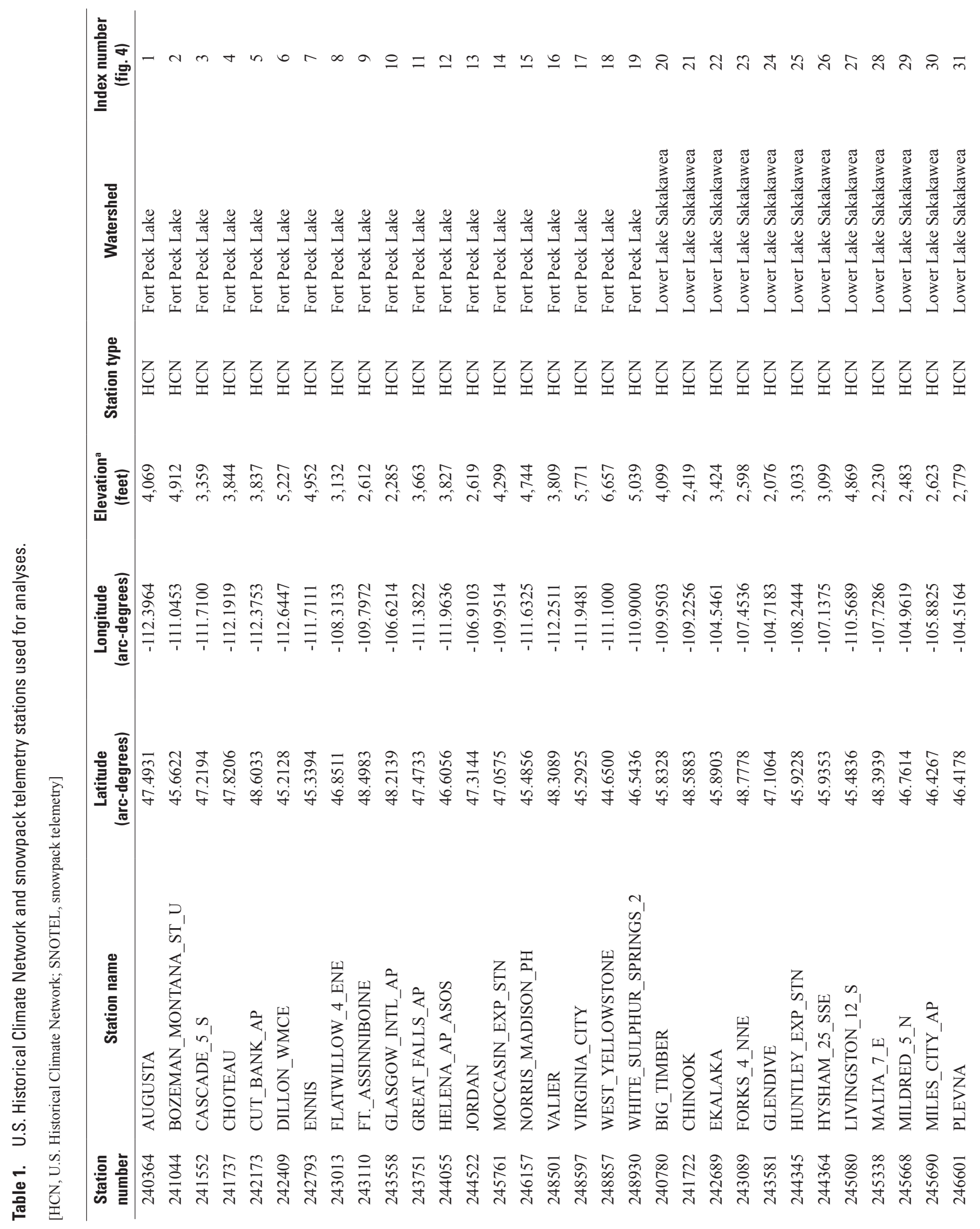




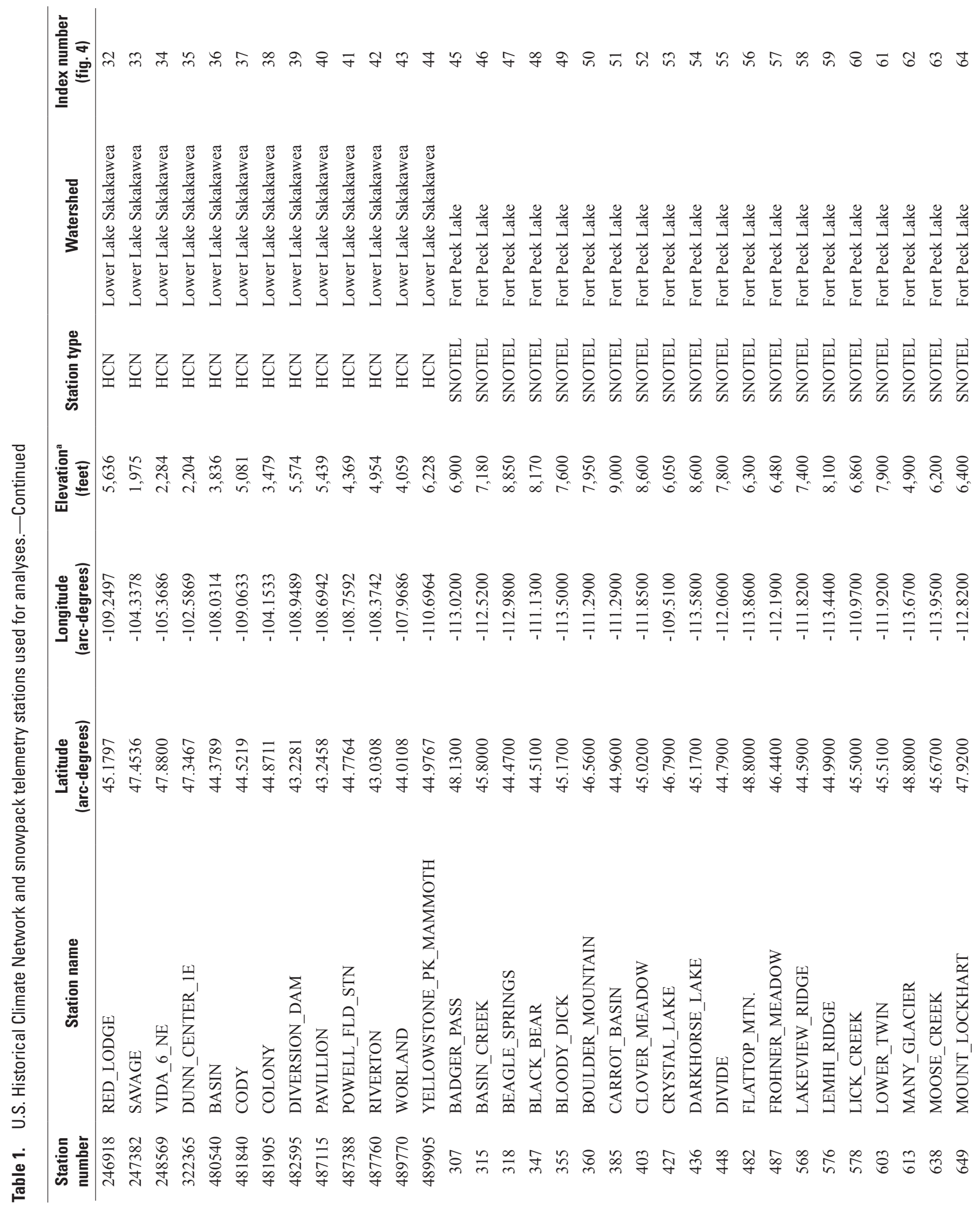




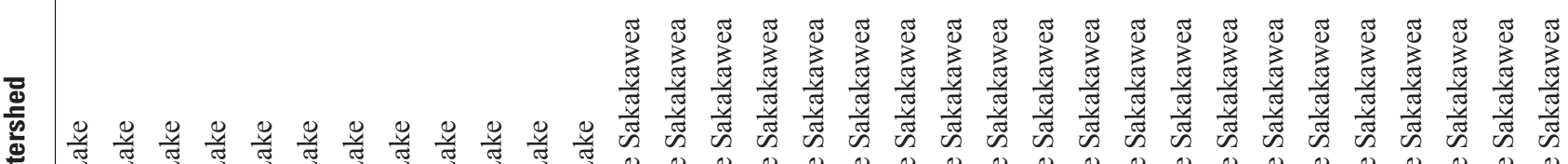

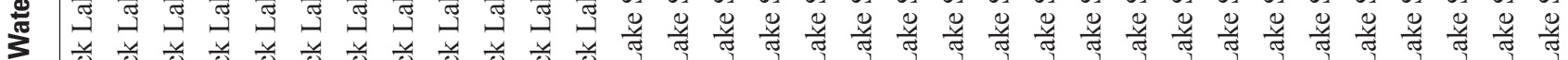

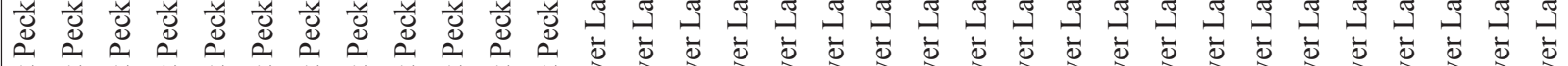

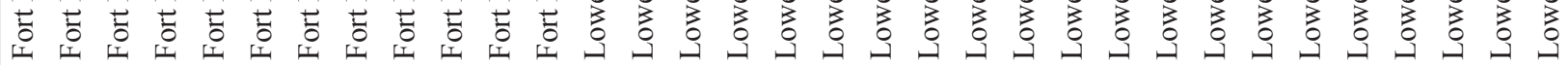

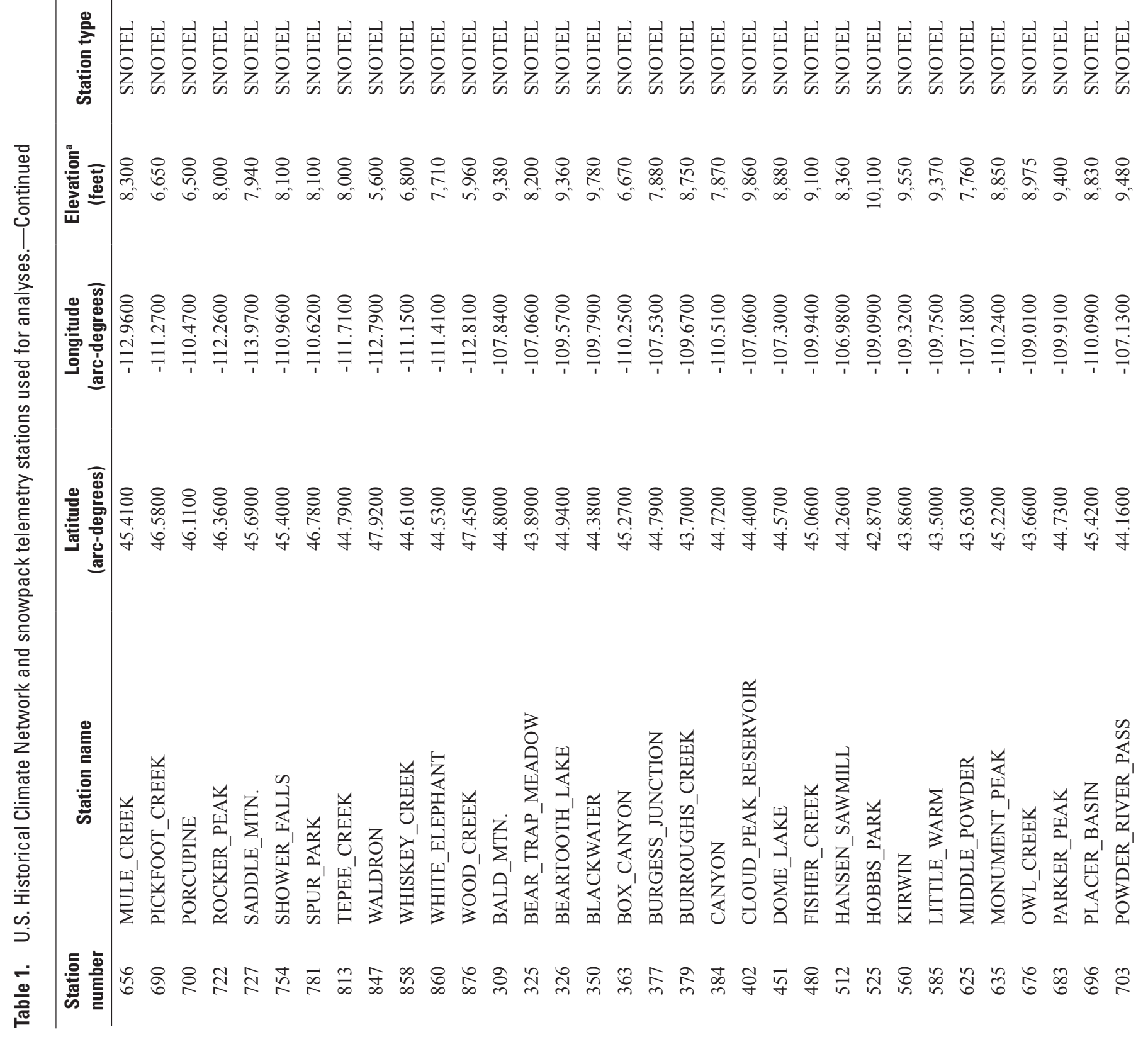




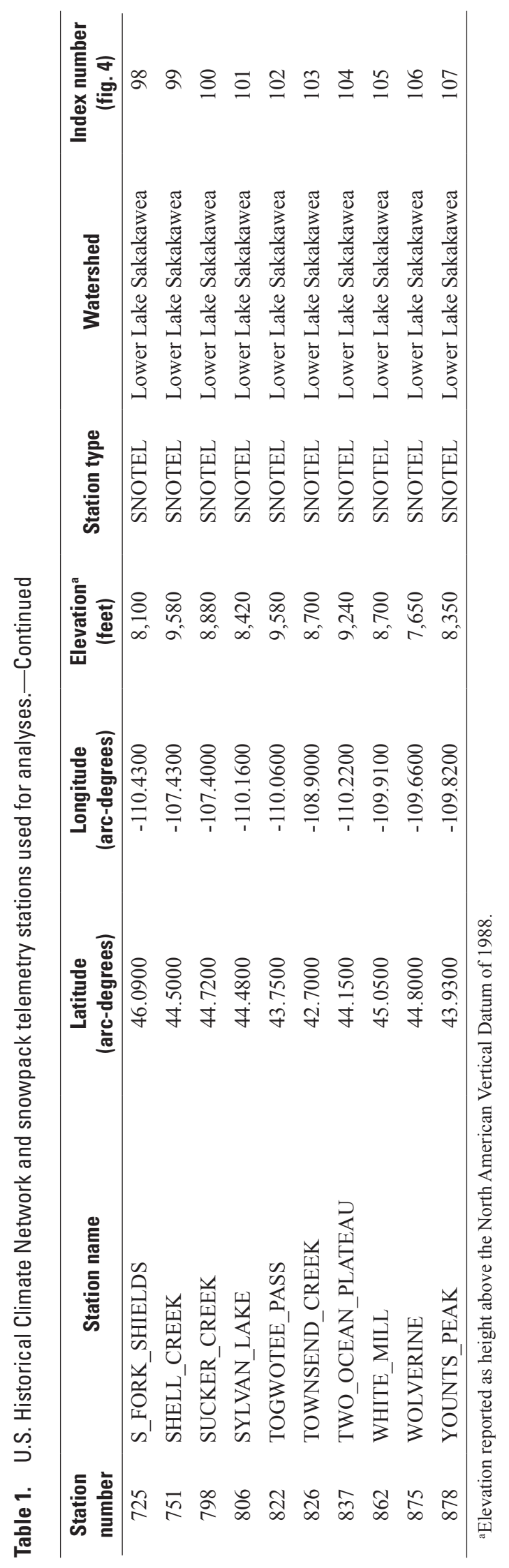


Table 2. Names and units of regressed and regressor variables for seasons and elevation zones as used in transfer functions.

[Peak snowpack is used as a regressed and regressor variable. Variables are computed for a runoff year, which is defined as beginning July 1 and ending the following June 30 of the specified year. Elevation ranges for the plains, foothills, and mountains elevation zones are height in feet above the North American Vertical Datum of 1988. <, less than; >, greater than]

\section{Regressed variables $^{\text {a }}$}

PEAKSWE Peak snowpack, as snow water equivalent (SWE), in inches

MJJRO May-June runoff, in acre-feet

\section{Regressor variables ${ }^{a, b}$}

PEAKSWE Peak snowpack, as SWE, in inches

\begin{tabular}{|c|c|c|c|}
\hline Season & $\begin{array}{c}\text { Plains } \\
(<7,000 \text { feet })\end{array}$ & $\begin{array}{c}\text { Foothills } \\
(7,000-8,500 \text { feet })\end{array}$ & $\begin{array}{l}\text { Mountains } \\
\text { (>8,500 feet) }\end{array}$ \\
\hline \multicolumn{4}{|c|}{ Seasonal mean of daily mean temperature, in degrees Fahrenheit } \\
\hline October, November, December & TAVEONDPLN & TAVEONDFTH & TAVEONDMTN \\
\hline January, February, March & TAVEJFMPLN & TAVEJFMFTH & TAVEJFMMTN \\
\hline July, August, September & PRECJASPLN & PRECJASFTH & PRECJASMTN \\
\hline October, November, December & PRECONDPLN & PRECONDFTH & PRECONDMTN \\
\hline January, February, March & PRECJFMPLN & PRECJFMFTH & PRECJFMMTN \\
\hline April, May, June & PRECAMJPLN & PRECAMJFTH & PRECAMJMTN \\
\hline January, February, March & EVAPJFMPLN & EVAP JFMFTH & EVAP JFMMTN \\
\hline April, May, June & EVAPAMJPLN & EVAPAMJFTH & EVAPAMJMTN \\
\hline
\end{tabular}

${ }^{a}$ Variable names are expressed in capital letters using Courier type font.

${ }^{b}$ These variable names are composed of letter combinations designating various abbreviations. The first four letters designate TAVE, mean of daily mean temperature; PREC, total precipitation; or EVAP, total reference evapotranspiration. The next three letters designate seasons as JAS, July, August, September; OND, October, November, December; JFM, January, February, March; or AMJ, April, May, June. The last three letters designate the elevation zones as PLN, plains elevation zone; FTH, foothills elevation zone; or MTN, mountains elevation zone.

variable for each watershed. This added 13 additional regressor variables, for a total of 37 regressor variables available for calibration of the May-July runoff transfer function for a given watershed (table 2).

\section{Historical Climatology Network and Snowpack Telemetry Station Data}

Historical weather station data were compiled from HCN records (Oak Ridge National Laboratory, 2014), and included monthly mean of daily mean surface air temperature, and monthly total precipitation. Historical weather station data also were compiled from the SNOTEL station records (Natural Resources Conservation Service, 2014), which also included monthly mean of daily mean surface air temperature, and monthly total precipitation. In addition, SNOTEL station records included daily snowpack as SWE height, in inches.
Links to digital HCN and SNOTEL data used for this study are provided in appendix 1.

Runoff year 1992 was selected as the start of the calibration period on the basis of available snowpack data, which were more limiting than available air temperature and precipitation data. Computation of defined regressor variables required complete station records from July 1991 through June 2011 resulting in a population of 107 stations of which 44 were HCN stations and 63 were SNOTEL stations (table 1). A total of $16 \mathrm{HCN}$ stations were within the Rocky Mountains physiographic division and 28 were within the Great Plains physiographic division. Two HCN stations were outside of the lower Lake Sakakawea watershed boundary, but were close to the boundary (within about $12 \mathrm{mi}$ ) and were, therefore, included in the analyses. All HCN stations were below 7,000 ft (maximum elevation of 6,657 ft). All SNOTEL stations were within the Rocky Mountains physiographic division, and eight SNOTEL stations that were outside the Missouri River Basin, 
Table 3. Station numbers excluded to bootstrap air temperature and precipitation regressor variables used for calibration and validation.

[Station numbers correspond to stations listed in table 1.]

\begin{tabular}{|c|c|c|c|c|}
\hline \multirow{2}{*}{$\begin{array}{l}\text { Elevation } \\
\text { zone }\end{array}$} & \multicolumn{4}{|c|}{ Bootstrap iteration } \\
\hline & 1 & 2 & 3 & 4 \\
\hline \multicolumn{5}{|c|}{ Fort Peck Lake watershed } \\
\hline Plains $^{\mathrm{a}}$ & 243558 & 243110 & 244522 & 243013 \\
\hline Foothills $^{\mathrm{b}}$ & 860 & 448 & 603 & 727 \\
\hline Mountains $^{\mathrm{c}}$ & 403 & 436 & 318 & 385 \\
\hline \multicolumn{5}{|c|}{ Lower Lake Sakakawea watershed } \\
\hline Plains $^{\mathrm{a}}$ & 247382 & 243581 & 322365 & 245338 \\
\hline Foothills ${ }^{\mathrm{b}}$ & 875 & 625 & 384 & 377 \\
\hline Mountains $^{\mathrm{c}}$ & 826 & 862 & 379 & 696 \\
\hline
\end{tabular}

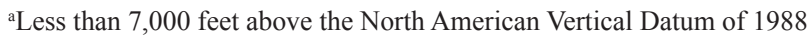
(NAVD 88).

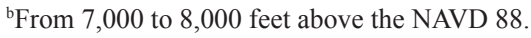

${ }^{\mathrm{c}}$ Greater than 8,000 feet above the NAVD 88.

but close to the basin boundary (within about $20 \mathrm{mi}$ ) were included in analyses. Within the Fort Peck Lake watershed, 13 SNOTEL stations were below 7,000 ft (minimum elevation of 4,900 ft) and in the plains elevation zone, 15 stations were between 7,000 and 8,500 ft and in the foothills elevation zone, and 4 stations were above $8,500 \mathrm{ft}$ (maximum elevation of $9,000 \mathrm{ft}$ ) and in the mountains elevation zone (fig. 4). Within the lower Lake Sakakawea watershed, 1 SNOTEL station was below 7,000 ft (minimum elevation of 4,900 ft), 9 stations were between 7,000 and $8,500 \mathrm{ft}$, and 21 stations were above $8,500 \mathrm{ft}$ (maximum elevation of 10,100 ft) (fig. 4).

\section{Community Climate System Model Output}

Peak snowpack and May-July runoff were computed on the basis of regressor variables derived from station observations, and also on the basis of daily precipitation and mean air temperature output from the CCSM, version 3.0 (CCSM3; Vertenstein and others, 2004) and from the CCSM, version 4.0 (CCSM4; Gent and others, 2011; Vertenstein and others, 2013). The CCSM3 and CCSM4 output for runoff years 1992 2099 were downloaded for analyses. Internet access to CCSM output is described in appendix 2. The CCSM3 output for 2000-99 assumes the A2 emission scenario (Nakićenović and Swart, 2000), and the CCSM4 assumes a representative concentration pathway of 8.5 watts per meter squared (RCP 8.5) of greenhouse gas forcing for 2005-2100 (Vuuren and others, 2011). The A2 emission scenario describes a world that places more importance on economy (A scenario) over environment (B scenario) and has regional responses to climate (2 scenario) more so than global cooperation (1 scenario). The A2 emission scenario is not the worst case scenario, but is a high emission scenario. The A2 emission scenario has been selected by the North American Regional Climate Change Assessment Program for dynamical downscaling (Mearns and others, 2009). The RCP 8.5 is a revised version of the A2 emission scenario (Vuuren and others, 2011). For these two reasons, the A2 and its revised version, RCP 8.5 , were selected for this study.

Because of the nature of AOGCMs, projected peak snowpack and May-July runoff computed on the basis of CCSM input will not precisely match that observed. For this reason, output for years preceding 2000 for CCSM3 and 2005 for CCSM4 are referred to as contemporary climate simulations, and years afterwards are referred to as projected climate simulations. The term "contemporary climate" implies that the model attempts to capture the characteristics of climate for a period, but is not constrained to match years (or months or days) precisely. To provide an analogy of the contrast between observed historical and contemporary climate, consider the behavior of walking a dog. A good model for the behavior of yesterday's walk is walking a dog along the same route today; however, you will not take the exact same steps, and neither will the dog, but you will be representing the dynamics of how you and the dog behaved yesterday. If you were constrained to follow exactly the same steps and timing of the previous day, you would not capture the appropriate response to changing external forcings, such as your response to a car approaching an intersection or a squirrel that distracts the dog. In a similar manner, contemporary climate simulated by AOGCMs is not constrained to hindcast historical climate precisely, but rather is a simulation of the dynamical behavior of weather and climate variability given external forcings (hydroclimatology). In this case, the forcing is increasing greenhouse gases.

Herein, historical climate will refer to simulations based on HCN and SNOTEL station observations for the period 1992-2011, contemporary climate will refer to simulations based on CCSM output for the period 1992-2011, and projected climate will refer to simulations based on CCSM output for the period 2012-99. The term "projected climate" also will be used when describing time series that span the contemporary and projected climate periods (1992-2099). Output for specific years simulated on the basis of CCSM output will be referred to as "simulation year," such as simulation year 2058. This is to emphasize that peak snowpack or May-July runoff estimated on the basis of CCSM output is not a prediction for that actual calendar year.

The grid spacing of CCSM3 output is about 1.4 arcdegrees of latitude and longitude, and the grid spacing for CCSM4 is about 0.94 arc-degrees of latitude by 1.25 arcdegrees of longitude. The CCSM grid spacing results in a generalized representation of terrain in the study area; for example, terrain representation (topography) for CCSM3 (fig. 7) has grid elevations less than 7,500 ft in the Upper Missouri River Basin, and the Rocky Mountains are represented as a single broad mountain range. As such, the climate dynamics at stations, such as might be typical for mountain settings 


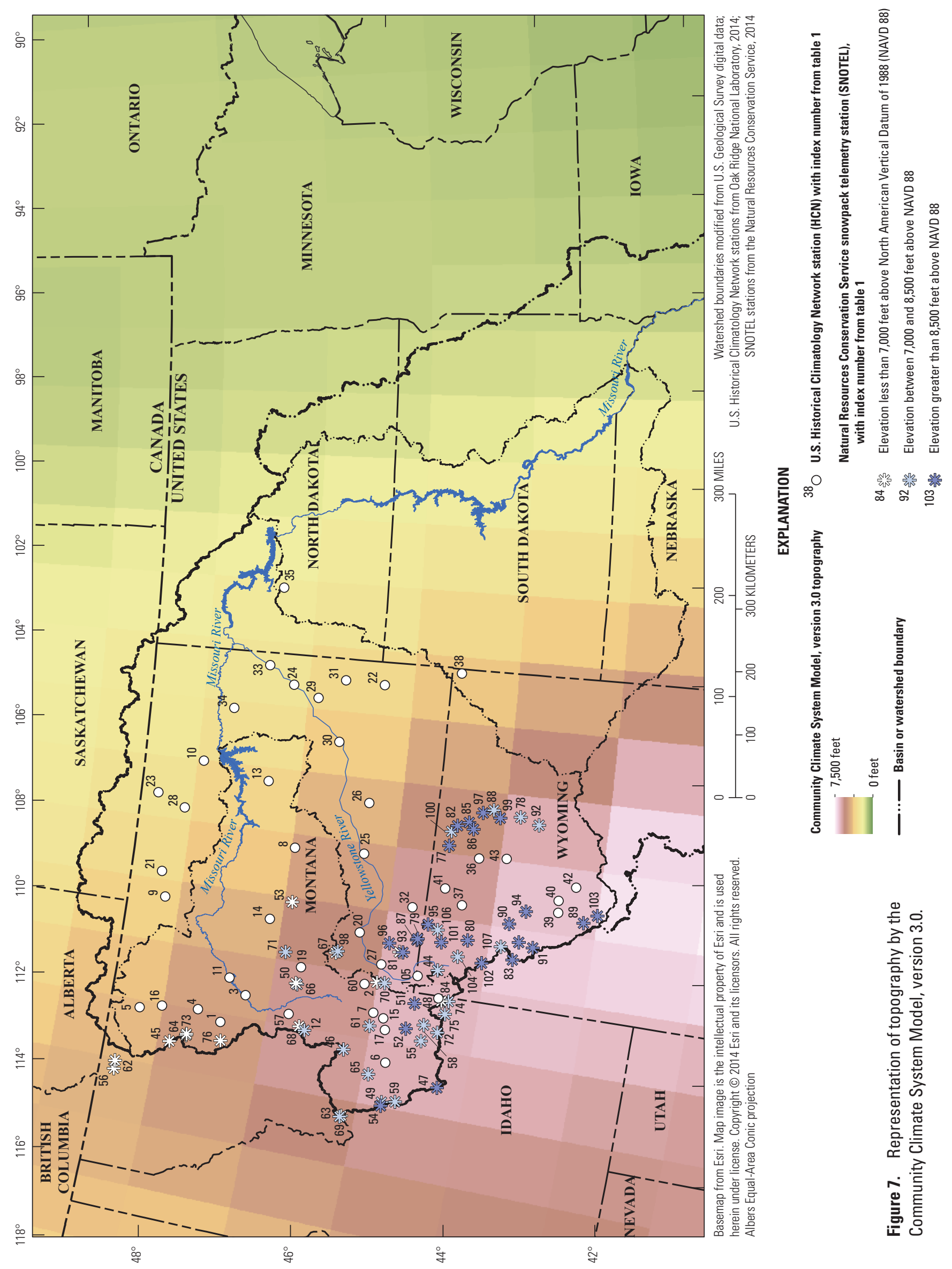


or plains, might not be well matched to the dynamics of the associated CCSM grid point.

The CCSM3 and CCSM4 output for July 1991-June 2099 (runoff years 1992-2099) of monthly mean air temperature and daily precipitation at grid points was interpolated to the locations of HCN and SNOTEL stations using a distancesquared weight applied to the four CCSM grid points surrounding the station. As a result, two sets of interpolated air temperature and precipitation were computed: one based on CCSM3 output and a second based on CCSM4 output. Links to interpolated CCSM3 and CCSM4 output are provided in appendix 3 .

Interpolated CCSM output was bias corrected for each month. Bias correction represent the difference between interpolated CCSM and observed (at HCN and SNOTEL stations) estimates of mean monthly air temperature and mean daily precipitation for July 1991-June 2011. Bias for daily precipitation was computed by adjusting CCSM output only for days with computed precipitation. An error was computed as the difference between observed monthly means of daily precipitation from HCN and SNOTEL station records and monthly means from bias-adjusted CCSM output. Bias adjustment potentially resulted in negative precipitation for some daily values, which were reset to zero. After negative values were reset to zero, error was recomputed. Bias was iteratively adjusted until error was within a tolerance of 0.001 inch per day (in/d) for a given month. Links to the bias-adjusted CCSM3 and CCSM4 output are provided in appendix 4. Regressor variables as described in the "Approach and Methods" section were similarly computed using bias-corrected CCSM3 and CCSM4 output for runoff years 1992-2099.

Because the CCSM-derived regressor variables were not used for calibration of transfer functions, the bootstrap method was not needed.

Bias correction shifts the mean, but bias correction has little or no effect on the standard deviation of CCSM output. Standard deviation of precipitation could be affected by bias correction because the minimum value is bounded by zero, whereas the maximum value is not bounded. The following departures of regressor variables computed using bias-corrected CCSM3 and CCSM4 output for 1992-2011 from regressor variables computed from HCN and SNOTEL stations (tables 4-6) were noted:

- greater standard deviation of OND, JFM, and AMJ air temperature for CCSM3 and CCSM4 output;

- greater standard deviation of CCSM3 precipitation with the exception of JFM for foothills and plains of the lower Lake Sakakawea watershed; and

- minimum and maximum precipitation for CCSM3 commonly exceeding the bounds of that observed.

Because bias-corrected CCSM3 output has greater standard deviation than that observed, and exceeds the bounds of that observed, confidence is reduced in simulations based on CCSM3 output relative to that based on CCSM4 output.

\section{Peak Snowpack}

Peak snowpack was used as a regressed and regressor variable. It was used as a regressor variable in the transfer function of May-July runoff. Peak snowpack is defined herein as the maximum daily snowpack recorded in a 12-month period from July through June. As such, the days considered in computation of peak snowpack span 2 calendar years. Peak snowpack was computed from daily snowpack at SNOTEL sites (fig. 4), and appendix 1 provides links to these data. The distribution of elevation ranges for SNOTEL stations are described previously in the "Historical Climatology Network and Snowpack Telemetry Station Data” section. All SNOTEL stations were located in the Rocky Mountains physiographic division. Peak snowpack is recorded as SWE with units of height, in inches.

Peak snowpack as a regressed or regressor variable represents the mean peak snowpack for all SNOTEL stations in a watershed for each runoff year. Bootstrapping was used to compute additional records for each runoff year. Stations removed for each bootstrap iteration are listed in table 7. As with other regressor variables, peak snowpack was computed for the Fort Peck and lower Lake Sakakawea watersheds. Sufficient records were not available to stratify peak snowpack by elevation and delete stations for the bootstrap method; therefore, peak snowpack was not stratified by elevation. In addition, given that peak snowpack is a regressed variable, stratification by elevation would require canonical regression techniques (Hotelling, 1936; Glahn, 1968) to simultaneously regress peak snowpack for each elevation zone. Future research might consider the use of canonical regression, which would allow for computation of peak snowpack and May-July runoff simultaneously.

\section{Reference Evapotranspiration}

Reference evapotranspiration is the evapotranspiration from a 4.72-in. high crop with a surface resistance of $21 \mathrm{sec}-$ onds per foot; an albedo of 0.23 ; and closely resembles a surface that is shaded, well-watered, and covered by growing grass (Irmak and Haman, 2003). Reference evapotranspiration was computed using the methodology of Hargreaves and Samani (1985), and is a function of latitude and monthly means of maximum, mean, and minimum air temperature. These functions are described by Snyder and Eching (2002) and Svoboda and others (2002). Links to the Python scripts used to compute reference evapotranspiration at $\mathrm{HCN}$ and SNOTEL station locations, including input and output data, are provided in appendix 5. The Python scripts compute reference evapotranspiration for the historical, contemporary, and projected periods.

Total reference evapotranspiration for each season and elevation zone is a regressor variable in the transfer function of May-July runoff (table 2). As with other regressor variables, separate sets of regressor variables for total reference 
Table 4. Standard deviation of seasonal precipitation and air temperature for 1992-2011 from observations at Historical Climate Network and snow telemetry stations, and Community Climate System Model, version 3.0 and version 4.0.

[JAS, July, August, September; OND, October, November, December; JFM, January, February, March; AMJ, April, May, June; OBS, observations at snow telemetry stations; CCSM3, Community Climate System Model, version 3.0; CCSM4, Community Climate System Model, version 4.0]

\begin{tabular}{|c|c|c|c|c|c|c|c|c|c|c|c|c|}
\hline \multirow{3}{*}{$\begin{array}{c}\text { Elevation } \\
\text { zone }\end{array}$} & \multicolumn{12}{|c|}{ Standard deviation of seasonal precipitation, in inches } \\
\hline & \multicolumn{3}{|c|}{ JAS } & \multicolumn{3}{|c|}{ OND } & \multicolumn{3}{|c|}{ JFM } & \multicolumn{3}{|c|}{ AMJ } \\
\hline & OBS & CCSM3 & CCSM4 & OBS & CCSM3 & CCSM4 & OBS & CCSM3 & CCSM4 & OBS & CCSM3 & CCSM4 \\
\hline Plains & 1.8 & 2.3 & 1.4 & 1.3 & 1.8 & 1.2 & 1.2 & 1.5 & 0.9 & 1.6 & 2.3 & 1.6 \\
\hline Foothills & 1.6 & 3.3 & 1.5 & 2.4 & 3.6 & 1.8 & 2.1 & 2.7 & 1.6 & 2.3 & 3.4 & 1.8 \\
\hline \multicolumn{13}{|c|}{ Lower Lake Sakakawea watershed } \\
\hline Plains & 1.0 & 1.6 & 1.1 & 0.7 & 1.1 & 0.7 & 0.5 & 0.9 & 0.5 & 1.4 & 1.7 & 1.4 \\
\hline Foothills & 1.2 & 2.3 & 1.7 & 1.7 & 2.3 & 1.5 & 1.6 & 1.2 & 1.0 & 2.2 & 3.1 & 2.0 \\
\hline Mountains & 1.3 & 2.5 & 1.9 & 2.1 & 2.6 & 1.7 & 2.2 & 1.6 & 1.3 & 2.5 & 3.4 & 2.0 \\
\hline
\end{tabular}

\begin{tabular}{|c|c|c|c|c|c|c|c|c|c|c|c|c|}
\hline \multirow{3}{*}{$\begin{array}{c}\text { Elevation } \\
\text { zone }\end{array}$} & \multicolumn{12}{|c|}{ Standard deviation of seasonal air temperature, in degrees Fahrenheit } \\
\hline & \multicolumn{3}{|c|}{ JAS } & \multicolumn{3}{|c|}{ OND } & \multicolumn{3}{|c|}{ JFM } & \multicolumn{3}{|c|}{ AMJ } \\
\hline & OBS & CCSM3 & CCSM4 & OBS & CCSM3 & CCSM4 & OBS & CCSM3 & CCSM4 & OBS & CCSM3 & $\operatorname{ccs} 44$ \\
\hline Plains & 2.4 & 2.3 & 1.8 & 2.4 & 4.0 & 3.7 & 2.9 & 4.2 & 5.7 & 1.7 & 2.3 & 2.5 \\
\hline Foothills & 2.7 & 2.4 & 1.7 & 2.5 & 3.5 & 2.9 & 2.3 & 3.9 & 5.0 & 2.2 & 2.2 & 2.9 \\
\hline \multicolumn{13}{|c|}{ Lower Lake Sakakawea watershed } \\
\hline Plains & 2.3 & 2.3 & 2.0 & 2.8 & 3.9 & 3.6 & 3.4 & 3.9 & 5.6 & 1.7 & 2.4 & 2.7 \\
\hline Foothills & 2.4 & 2.6 & 1.8 & 2.6 & 3.4 & 2.8 & 2.4 & 4.0 & 5.0 & 2.1 & 2.4 & 2.9 \\
\hline Mountains & 2.3 & 2.6 & 1.8 & 2.5 & 3.3 & 2.8 & 2.2 & 4.0 & 4.9 & 2.3 & 2.4 & 3.0 \\
\hline
\end{tabular}

evapotranspiration were computed for the Fort Peck Lake and lower Lake Sakakawea watersheds. Regressor variables for the historical and projected periods were computed using methods described for air temperature and precipitation. Regressor variables for the historical period were bootstrapped by excluding the stations listed in table 7. Bootstrapped records were randomly sampled to provide 95 records for calibration and 5 records for validation.

\section{Modern (1992-2011) and Projected (2012-99) Peak Snowpack}

The peak snowpack transfer functions (models) for the Fort Peck Lake and lower Lake Sakakawea watersheds were calibrated for runoff years 1992-2011. All dates included in this section are for runoff years. The calibrated models (transfer functions) then were used to estimate modern (1992-2011) and projected (2012-99) peak snowpack for the Fort Peck Lake and lower Lake Sakakawea watersheds.

\section{Model Calibration}

The peak snowpack transfer function was calibrated using multiple linear regression on regressor variables that represented seasonal means of air temperature and precipitation records at $\mathrm{HCN}$ and SNOTEL stations stratified by elevation and watershed for the period of 1992-2011. Regressor variables were bootstrapped, and the regressed variable (peak snowpack) also was bootstrapped by excluding SNOTEL stations listed in table 7. Stepwise regression was used to reduce the number of regressor variables from 24 to 22 for the Fort Peck Lake and lower Lake Sakakawea watershed transfer functions. The incremental change in multiple $R^{2}$ values with addition of variables was used to reduce the number of variables computed by stepwise regression to five for the Fort Peck Lake watershed transfer function and four for the lower Lake Sakakawea transfer function (table 8). The change in multiple $R^{2}$ values with addition of regressor variables is shown in figure 8 , and the resulting transfer functions had multiple $R^{2}$ values of 0.92 and 0.96 for the Fort Peck Lake and lower Lake Sakakawea watersheds, respectively. The regressor 
Table 5. Minimum value of seasonal precipitation and air temperature for 1992-2011 from observations at Historical Climate Network and snow telemetry stations, and Community Climate System Model, version 3.0 and version 4.0.

[JAS, July, August, September; OND, October, November, December; JFM, January, February, March; AMJ, April, May, June; OBS, observations at snow telemetry stations; CCSM3, Community Climate System Model, version 3.0; CCSM4, Community Climate System Model, version 4.0]

\begin{tabular}{|c|c|c|c|c|c|c|c|c|c|c|c|c|}
\hline \multirow{3}{*}{$\begin{array}{c}\text { Elevation } \\
\text { zone }\end{array}$} & \multicolumn{12}{|c|}{ Minimum value of seasonal precipitation, in inches } \\
\hline & \multicolumn{3}{|c|}{ JAS } & \multicolumn{3}{|c|}{ OND } & \multicolumn{3}{|c|}{ JFM } & \multicolumn{3}{|c|}{ AMJ } \\
\hline & OBS & CCSM3 & CCSM4 & OBS & CCSM3 & CCSM4 & OBS & CCSM3 & CCSM4 & OBS & CCSM3 & CCSM4 \\
\hline Plains & 2.1 & 0.5 & 1.9 & 3.2 & 2.5 & 3.7 & 2.9 & 2.6 & 2.7 & 6.6 & 3.6 & 6.2 \\
\hline Foothills & 2.7 & 0.2 & 2.0 & 5.4 & 3.2 & 6.0 & 5.3 & 3.0 & 5.4 & 8.0 & 2.8 & 8.2 \\
\hline \multicolumn{13}{|c|}{ Lower Lake Sakakawea watershed } \\
\hline Plains & 2.1 & 0.7 & 1.6 & 1.1 & 0.7 & 1.0 & 1.0 & 0.8 & 0.8 & 3.9 & 3.1 & 4.1 \\
\hline Foothills & 3.1 & 0.8 & 3.0 & 4.8 & 2.3 & 4.5 & 3.6 & 3.7 & 4.1 & 6.2 & 3.3 & 7.2 \\
\hline Mountains & 3.5 & 0.9 & 2.9 & 5.6 & 2.5 & 5.6 & 4.4 & 4.7 & 5.3 & 6.0 & 2.9 & 7.9 \\
\hline
\end{tabular}

\begin{tabular}{|c|c|c|c|c|c|c|c|c|c|c|c|c|}
\hline \multirow{3}{*}{$\begin{array}{c}\text { Elevation } \\
\text { zone }\end{array}$} & \multicolumn{12}{|c|}{ Minimum value of seasonal air temperature, in degrees Fahrenheit } \\
\hline & \multicolumn{3}{|c|}{ JAS } & \multicolumn{3}{|c|}{ OND } & \multicolumn{3}{|c|}{ JFM } & \multicolumn{3}{|c|}{ AMJ } \\
\hline & OBS & CCSM3 & CCSM4 & OBS & CCSM3 & CCSM4 & OBS & CCSM3 & CCSM4 & OBS & CCSM3 & CCSM4 \\
\hline Plains & 52 & 54 & 56 & 26 & 23 & 21 & 19 & 16 & 15 & 44 & 42 & 43 \\
\hline Foothills & 45 & 47 & 50 & 21 & 19 & 19 & 17 & 13 & 12 & 36 & 35 & 34 \\
\hline \multicolumn{13}{|c|}{ Lower Lake Sakakawea watershed } \\
\hline Plains & 59 & 60 & 62 & 27 & 26 & 22 & 20 & 17 & 14 & 50 & 49 & 49 \\
\hline Foothills & 46 & 47 & 50 & 23 & 20 & 20 & 17 & 14 & 12 & 36 & 37 & 37 \\
\hline Mountains & 43 & 44 & 47 & 20 & 17 & 18 & 15 & 11 & 9 & 33 & 33 & 34 \\
\hline
\end{tabular}

variables and associated coefficients for the transfer functions are listed in table 8 , and models for both watersheds have the following common regressors:

- precipitation in JFM and OND had the largest coefficient of regressor variables for both watersheds, but was associated with the foothills elevation zone for the Fort Peck Lake watershed and the mountain elevation zone for the lower Lake Sakakawea watershed;

- air temperature in OND for the plains elevation zone was included in both regression equations; and

- precipitation in JFM for the mountains elevation zone was included in both models, but has the smallest coefficient of precipitation variables for the Fort Peck Lake watershed transfer function.

In summary, regressor variables with highest coefficients were associated with JFM and OND precipitation, and the foothills and mountains for the Fort Peck Lake watershed, in contrast to the mountains for the lower Lake Sakakawea watershed. This might reflect bias in the elevation distribution of SNOTEL stations in the study area. Although all SNOTEL stations were in the Rocky Mountains, the Fort Peck Lake watershed had SNOTEL stations at lower elevations than SNOTEL stations in the lower Lake Sakakawea watershed. The elevation of SNOTEL stations ranged from 4,900 to 9,000 ft for the Fort Peck Lake watershed in contrast to 6,670 to $10,100 \mathrm{ft}$ for the lower Lake Sakakawea watershed (table 1, fig. 4); therefore, the Fort Peck Lake watershed regression model was calibrated to peak snowpack at elevations more closely aligned with the foothills elevation zone.

\section{Modern (1992-2011) Peak Snowpack as Snow Water Equivalent}

Peak snowpack for the Fort Peck Lake watershed and for the lower Lake Sakakawea watershed (figs. 9 and 10, respectively) was computed as snow water equivalent (in inches) for runoff years 1992-2011 using calibration and validation regressor variables computed from $\mathrm{HCN}$ and SNOTEL station records. Plots of the relation between regressed peak snowpack and observed peak snowpack show a close 
Table 6. Maximum value of seasonal precipitation and air temperature for 1992-2011 from observations at Historical Climate Network and snow telemetry stations, and Community Climate System Model, version 3.0 and version 4.0.

[JAS, July, August, September; OND, October, November, December; JFM, January, February, March; AMJ, April, May, June; OBS, observations at snow telemetry stations; CCSM3, Community Climate System Model, version 3.0; CCSM4, Community Climate System Model, version 4.0]

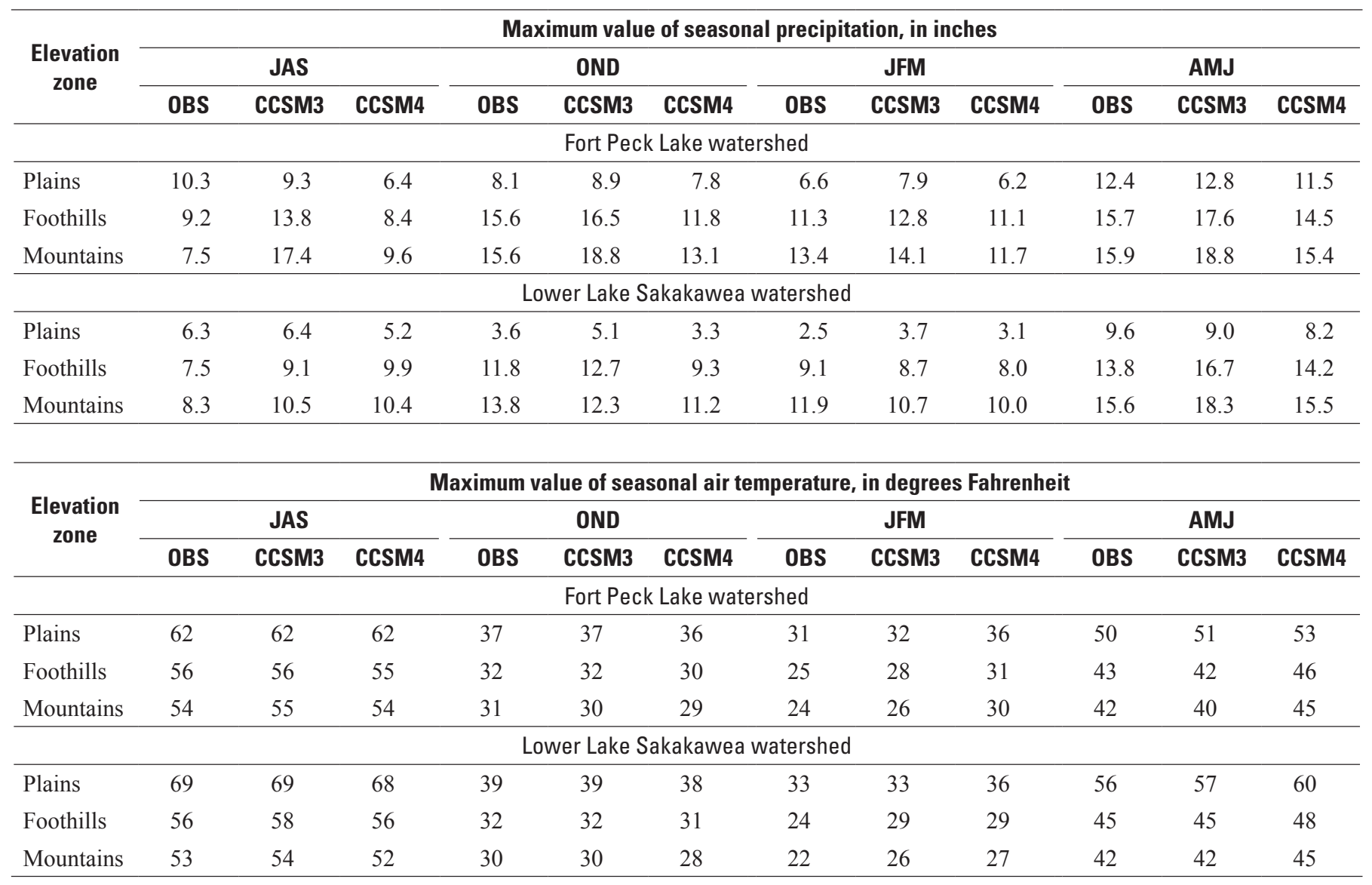

correspondence for the calibration and validation datasets (figs. 9-12); and based on a paired Student's t-test (Ott, 1993), means of regressed and observed peak snowpack were not significantly different from zero at a 0.05 probability (table 9 ).

Peak snowpack also was computed for 1992-2011 on the basis of regressor variables computed from CCSM3 and CCSM4 output for the Fort Peck Lake watershed and for the lower Lake Sakakawea watershed (figs. 9 and 10, respectively). As previously described in the "Community Climate System Model Output” section, regressed peak snowpack computed on the basis of CCSM3 and CCSM4 will not precisely match that observed for each year; however, the goal is to match the hydroclimatology of that observed. Student's t-tests, assuming unequal variances of populations, indicate no significant differences between observed mean peak snowpack and regressed mean peak snowpack from CCSM3 and CCSM4 at a 0.05 probability for the Fort Peck Lake and lower Lake Sakakawea watersheds (table 9).

For the Fort Peck Lake and lower Lake Sakakawea watersheds, mean peak snowpack regressed from CCSM3 and CCSM4 for 1992-2011 were similar to observed mean peak snowpack at SNOTEL stations (table 10). The maximum peak snowpack regressed from CCSM3 and CCSM4 was underpredicted for both watersheds. The minimum peak snowpack regressed from CCSM3 was under-predicted for both watersheds, regressed from CCSM4 for the Fort Peck Lake watershed was underpredicted, and regressed from CCSM4 for the lower Lake Sakakawea watershed was overpredicted. The standard deviation of peak snowpack regressed by CCSM3 was similar to that observed, and was underpredicted by CCSM4. 
Table 7. Station numbers excluded to bootstrap the regressed and regressor variables for peak snowpack.

[Station numbers correspond to stations listed in table 1.]

\begin{tabular}{lcccc}
\hline \multirow{2}{*}{ Watershed } & \multicolumn{4}{c}{ Bootstrap iteration } \\
\cline { 2 - 5 } & $\mathbf{1}$ & $\mathbf{2}$ & $\mathbf{3}$ & $\mathbf{4}$ \\
\hline Fort Peck Lake & 403 & 436 & 318 & 385 \\
Lower Lake Sakakawea & 826 & 862 & 379 & 696 \\
\hline
\end{tabular}

Table 8. Coefficients of peak snowpack transfer functions for the Fort Peck Lake and lower Lake Sakakawea watersheds.

[All variables were significant at the 0.001 probability. --, not applicable]

\begin{tabular}{|c|c|c|c|}
\hline \multicolumn{2}{|c|}{ Fort Peck Lake watershed } & \multicolumn{2}{|c|}{$\begin{array}{c}\text { Lower Lake Sakakawea } \\
\text { watershed }\end{array}$} \\
\hline \multicolumn{2}{|c|}{$\begin{array}{l}\text { Regression equation } \\
\text { intercept }=35.56\end{array}$} & \multicolumn{2}{|c|}{$\begin{array}{l}\text { Regression equation } \\
\text { intercept }=\mathbf{3 . 6 8}\end{array}$} \\
\hline Variable $e^{a, b}$ & Coefficient & Variable $e^{a, b}$ & Coefficient \\
\hline PRECJFMFTH & 0.75 & PRECONDMTN & 0.86 \\
\hline PRECONDFTH & 0.71 & PRECJFMMTN & 1.28 \\
\hline TAVEAMJPLN & -0.53 & PRECAMJMTN & 0.51 \\
\hline PREC JFMMTN & 0.39 & TAVEONDPLN & -0.26 \\
\hline TAVEONDPLN & -0.25 & -- & -- \\
\hline
\end{tabular}

${ }^{a}$ Variable names are expressed in captial letters using Courier type font.

${ }^{b}$ These variable names are composed of letter combinations designating various abbreviations as defined in table 2. Abbreviations applicable to the variables in this table follow: TAVE, mean of daily mean temperature; PREC, total precipitation; OND, October, November, December; JFM, January, February, March; AMJ, April, May, June; PLN, plains elevation zone; FTH, foothills elevation zone; MTN, mountains elevation zone.

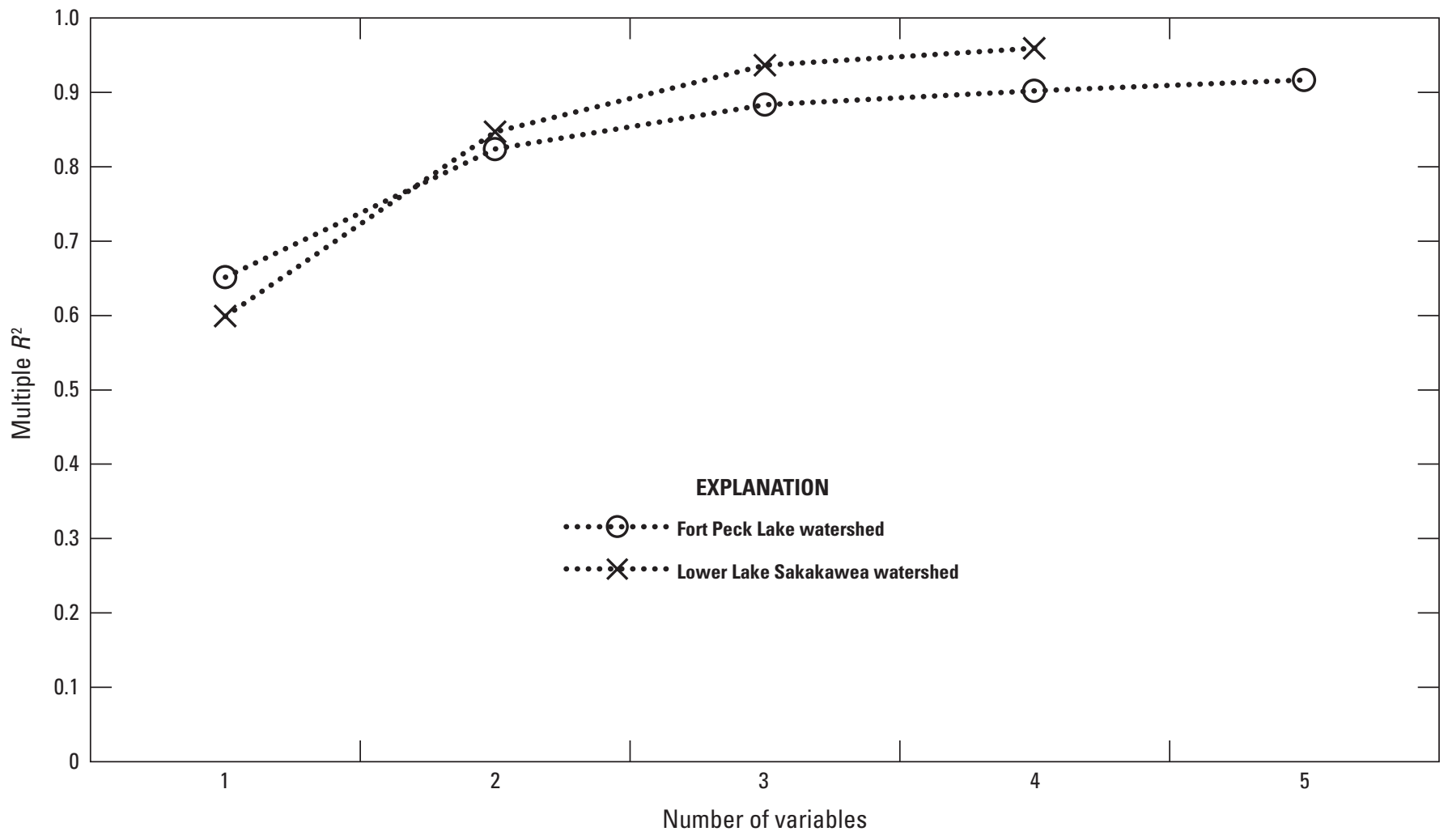

Figure 8. Incremental increase in multiple coefficient of determination $\left(R^{2}\right)$ values with addition of regressor variables in table 8. 


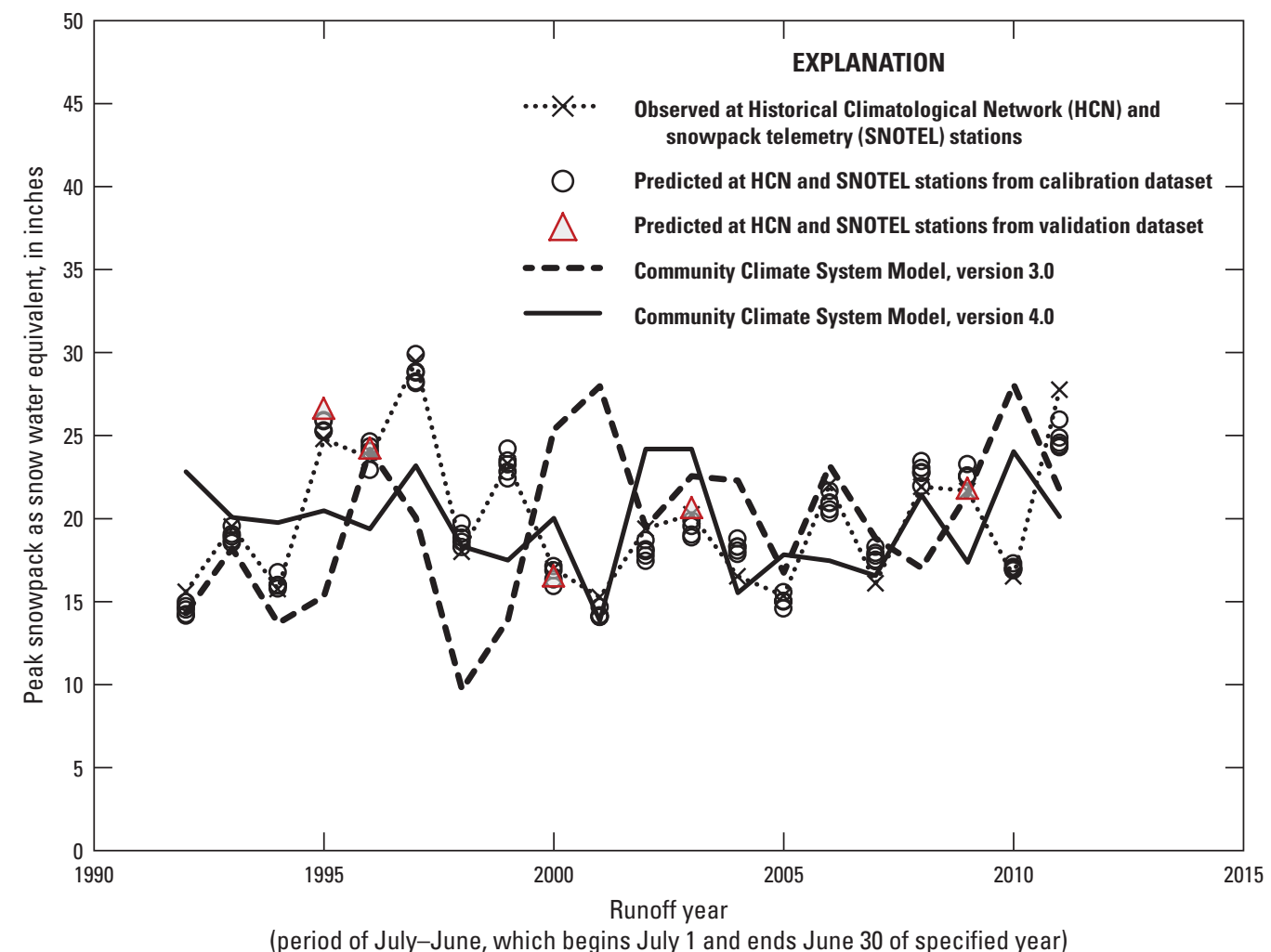

Figure 9. Peak snowpack for runoff years 1992-2011 for the Fort Peck Lake watershed. Multiple calibration points for each runoff year are a product of the bootstrap method.

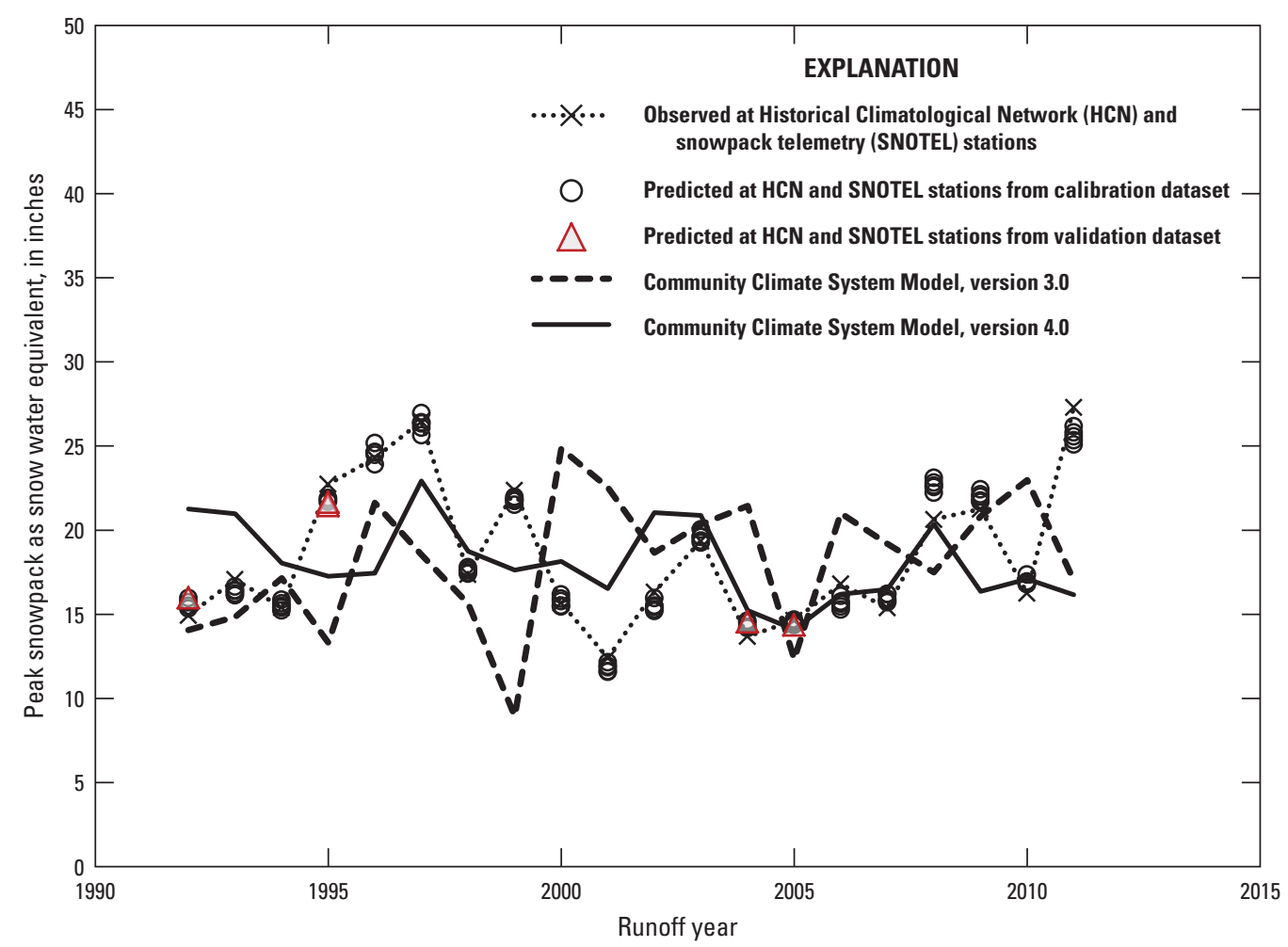

(period of July-June, which begins July 1 and ends June 30 of specified year)

Figure 10. Peak snowpack as snow water equivalent for a runoff years 1992-2011 for the lower Lake Sakakawea watershed. Multiple calibration points for each runoff year are a product of the bootstrap method. 


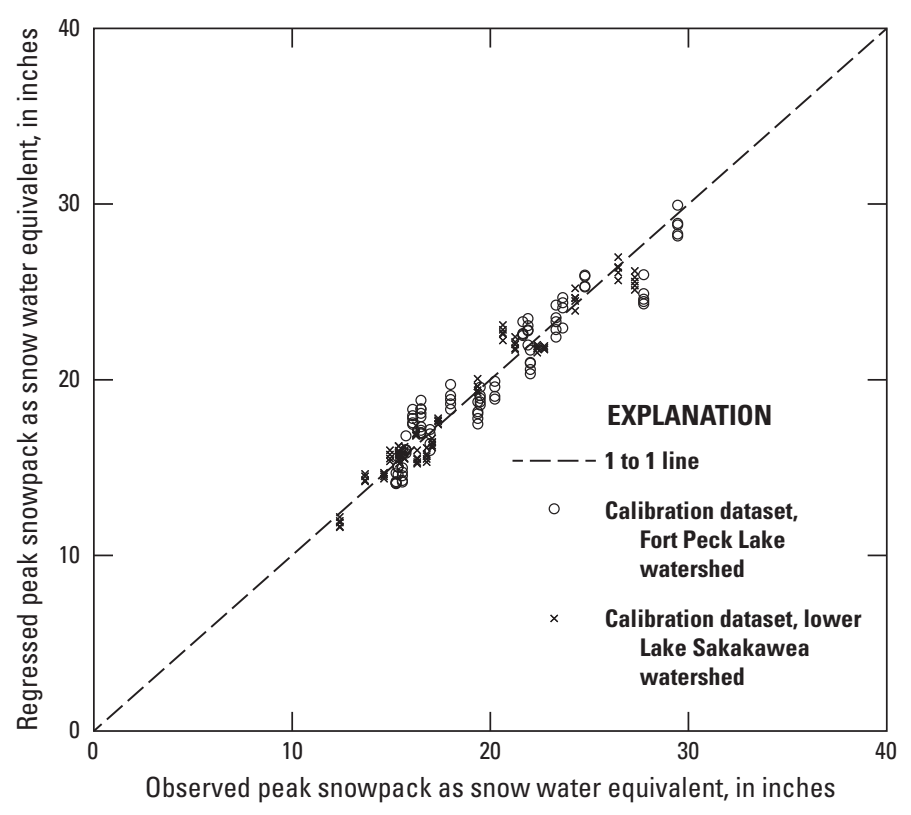

Figure 11. Relation between regressed peak snowpack and observed peak snowpack at snowpack telemetry stations used for calibration, Fort Peck Lake and lower Lake Sakakawea watersheds.

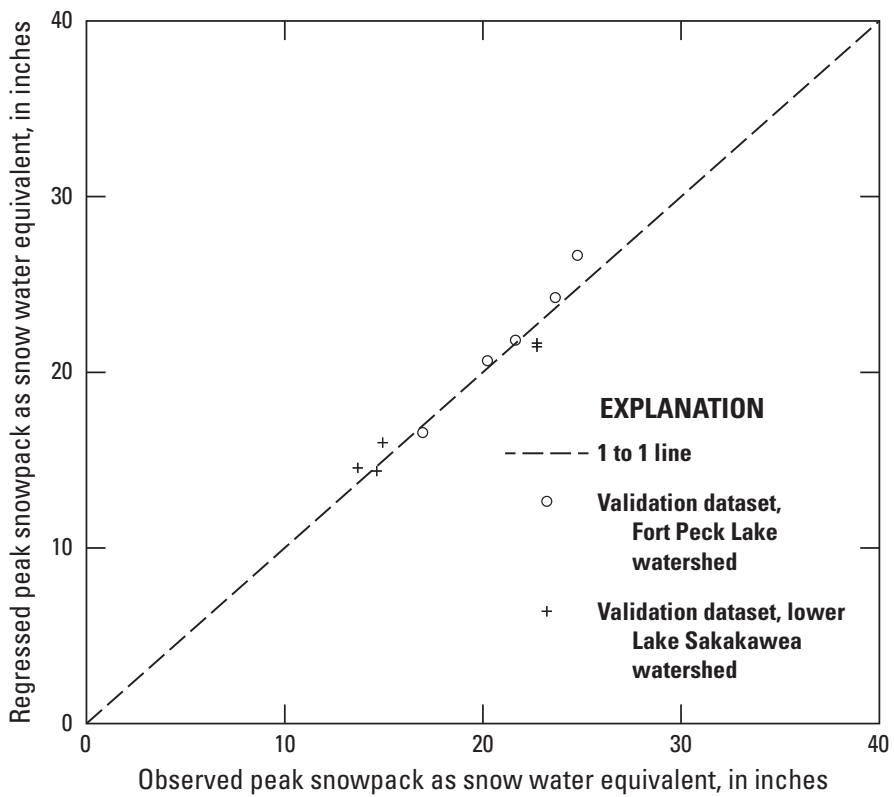

Figure 12. Relation between regressed peak snowpack and observed peak snowpack at snowpack telemetry stations used for validation, Fort Peck Lake and lower Lake Sakakawea watersheds.

Table 9. Results of paired Student's t-tests for the null hypothesis that observed and regressed peak snowpack have equal means.

[Means were not significantly different at the 0.05 probability for all tests. Student's t-tests for validation and calibration datasets are paired, and for Community Climate System Model, versions 3 and 4, are two-tailed, and two-samples with unequal variance. CCSM3, regressed from transfer function applied to the Community Climate System Model, version 3.0 output; CCSM4, regressed from transfer function applied to the Community Climate System Model, version 4.0]

\begin{tabular}{lccccc}
\hline \multirow{2}{*}{ Dataset } & \multicolumn{2}{c}{ Fort Peck Lake watershed } & & \multicolumn{2}{c}{ Lower Lake Sakakawea watershed } \\
\cline { 2 - 3 } \cline { 5 - 6 } & t-value & Probability & & t-value & Probability \\
\hline Calibration & 0.987 & 0.326 & & 0.080 & 0.936 \\
Validation & -1.380 & 0.239 & & 0.277 & 0.796 \\
CCSM3 & 0.199 & 0.843 & & 0.285 & 0.777 \\
CCSM4 & 0.250 & 0.805 & & 0.343 & 0.734 \\
\hline
\end{tabular}

Table 10. Summary statistics for observed and regressed peak snowpack for runoff years 1992-2011.

[A runoff year is the period July-June (begins July 1 and ends June 30 of specified year). CCSM3, regressed from the Community Climate System Model, version 3.0 output; CCSM4, regressed from the Community Climate System Model, version 4.0 output]

\begin{tabular}{lccccccc}
\hline \multirow{2}{*}{ Statistic } & \multicolumn{5}{c}{ Peak snowpack as snow water equivalent, in inches } \\
\cline { 2 - 3 } & \multicolumn{2}{c}{ Fort Peck Lake watershed } & & \multicolumn{2}{c}{ Lower Lake Sakakawea watershed } \\
\cline { 2 - 3 } \cline { 6 - 8 } & Observed & CCSM3 & CCSM4 & & Observed & CCSM3 & CCSM4 \\
\hline Mean & 19.99 & 19.70 & 19.70 & & 18.52 & 18.14 & 18.14 \\
Maximum & 29.47 & 28.08 & 24.19 & & 27.30 & 24.84 & 22.93 \\
Minimum & 15.27 & 9.70 & 13.85 & & 12.41 & 8.95 & 14.10 \\
Standard deviation & 4.25 & 4.93 & 2.97 & & 4.30 & 4.04 & 2.36 \\
\hline
\end{tabular}




\section{Projected (2012-99) Peak Snowpack}

Peak snowpack as snow water equivalent (in inches) was projected for runoff years 2012-99 by applying the transfer function for peak snowpack to regressor variables computed from CCSM3 and CCSM4 output for the Fort Peck Lake and lower Lake Sakakawea watersheds (figs. 13-14, respectively). Trends for the projection period were tested for significance using the Kendall's tau nonparametric test (Kendall, 1938). Change in variance was tested for significance using the Breusch-Pagan test (Breusch and Pagan, 1979). Significance was based on a 0.05 probability of a Type I error: reject null hypothesis of "no trend" when no trend exists.

Projected peak snowpack for 2012-99 for the Fort Peck Lake watershed indicate significant downward trends in regressed peak snowpack computed on the basis of CCSM3 and CCSM4 output (fig. 13). During the 88-year period 2012-99, 17 and 25 percent of years had peak snowpack less than the minimum observed for 1992-2011 for CCSM3 and CCSM4, respectively. The regressed peak snowpack for CCSM3 and CCSM4 for the final 10 years (2090-99) was below the observed minimum peak snowpack for 4 and 6 years, respectively, and below observed mean peak snowpack for 9 and 10 years, respectively. Downward trends in peak snowpack were consistent with the observed downward trends in annual streamflow for this region for 1960-2010 as reported by Norton and others (2014).

In contrast to the Fort Peck Lake watershed, projected peak snowpack for 2012-99 for the lower Lake Sakakawea watershed indicates no trends in regressed peak snowpack computed on the basis of CCSM3 and CCSM4 output (fig. 14); however, the variance of projected peak snowpack as computed from CCSM3 output increased substantially, which resulted in projections for the later part of the time series that were outside of the observed range (fig. 14). During the 88-year period 2012-99, 2 and 0 percent of years had peak snowpack less than the minimum observed for 1992-2011 for CCSM3 and CCSM4, respectively. The contrast of the two watersheds reflects the differences in regressor variables in the respective transfer functions. Downward trends in peak snowpack would be associated with upward trends in air temperature regressor variables (fig. 15). The transfer function for the Fort Peck Lake watershed includes two regressor variables for air temperature compared to one regressor variable for air temperature for the lower Lake Sakakawea watershed transfer function (table 8). Coefficients for air temperature regressors are also larger for the Fort Peck Lake watershed transfer functions than in the lower Lake Sakakawea transfer function (table 8). In summary, peak snowpack in the Fort Peck Lake watershed could be hypothesized to be more sensitive to air temperature than in the lower Lake Sakakawea watershed. This may reflect the lower elevations of SNOTEL stations in the Fort Peck Lake watershed, which would be associated with higher air temperatures that could affect snowpack.

Calibration of statistical models, such as the transfer functions used herein, generally assume that regressed variables will be computed on the basis of regressor variables within the range used for calibration. As previously described, projected peak snowpack had a trend for the Fort Peck Lake watershed that resulted in peak snowpack outside of the range observed for 1992-2011. The CCSM3 and CCSM4 regressor variables that represent seasonal air temperature were analyzed by summing the number of years in a moving 10 -year window that were outside of the range used for calibration (table 11). In general for both watersheds, regressor variables that represent seasonal air temperature had on average 5 to 6 years within moving 10-year windows that were outside of bounds used for calibration by runoff year 2060 and increasing in subsequent years. In the final 10 years (2090-99), on average 9 years were outside the range used for calibration; therefore, regressed peak snowpack for 2060-99 would have less certainty than for preceding years. This uncertainty will also hold for projections of May-July runoff for 2060-99 that are described in the "May-July Runoff" section. Trends for these periods might remain of value, but actual values of peak snowpack or May-July runoff would be less certain.

\section{Modern (1992-2011) and Projected (2012-99) May-July Runoff}

The May-July runoff transfer functions (models) for the Fort Peck Lake and lower Lake Sakakawea watersheds were calibrated for runoff years 1992-2011. All dates included in this section are for runoff years. The calibrated models (transfer functions) then were used to estimate modern (1992-2011) and projected (2012-99) May-July runoff for the watersheds. The projected May-July runoff was used to project power generation at Fort Peck and Garrison Dams for the period 2012-99 and to determine whether projected runoff would be on the order of magnitude as that observed in 2011.

\section{Model Calibration}

The transfer function for May-July runoff was calibrated using multivariate linear regression and stepwise techniques, similar to the methodology described for peak snowpack, for 1992-2011. The methodology differs in that a logarithmic transformation was applied to May-July runoff. This transformation restricts regressed May-July runoff to values greater than zero. Regressor variables used for calibration, validation, and projection include those used for peak snowpack with the addition of peak snowpack and seasonal evapotranspiration for elevation zones. The model was calibrated using bootstrapped peak snowpack (from SNOTEL station records) as a regressor variable. Bootstrap methods were used to increase the number of records for calibration and validation by excluding stations listed in table 3 as described in the "Approach and Methods" section; however, May-July runoff records could not be bootstrapped for calibration and validation because May-July 


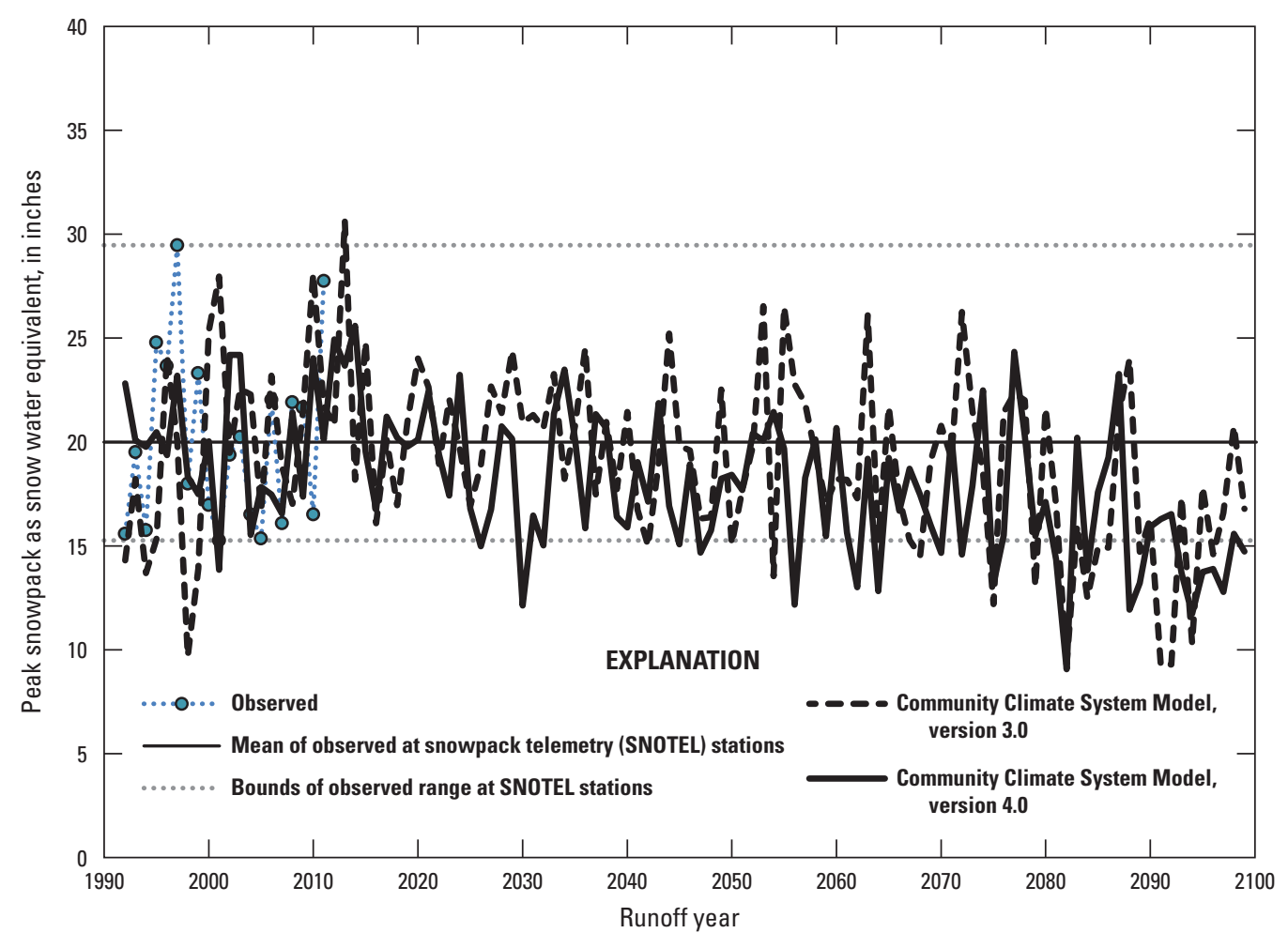

(period of July-June, which begins July 1 and ends June 30 of specified year)

Figure 13. Projections of peak snowpack for runoff years 1992-2099 for the Fort Peck Lake watershed. The Community Climate System Model, version 3.0 assumes the A2 emission scenario and version 4.0 assumes representative concentration pathway 8.5 .

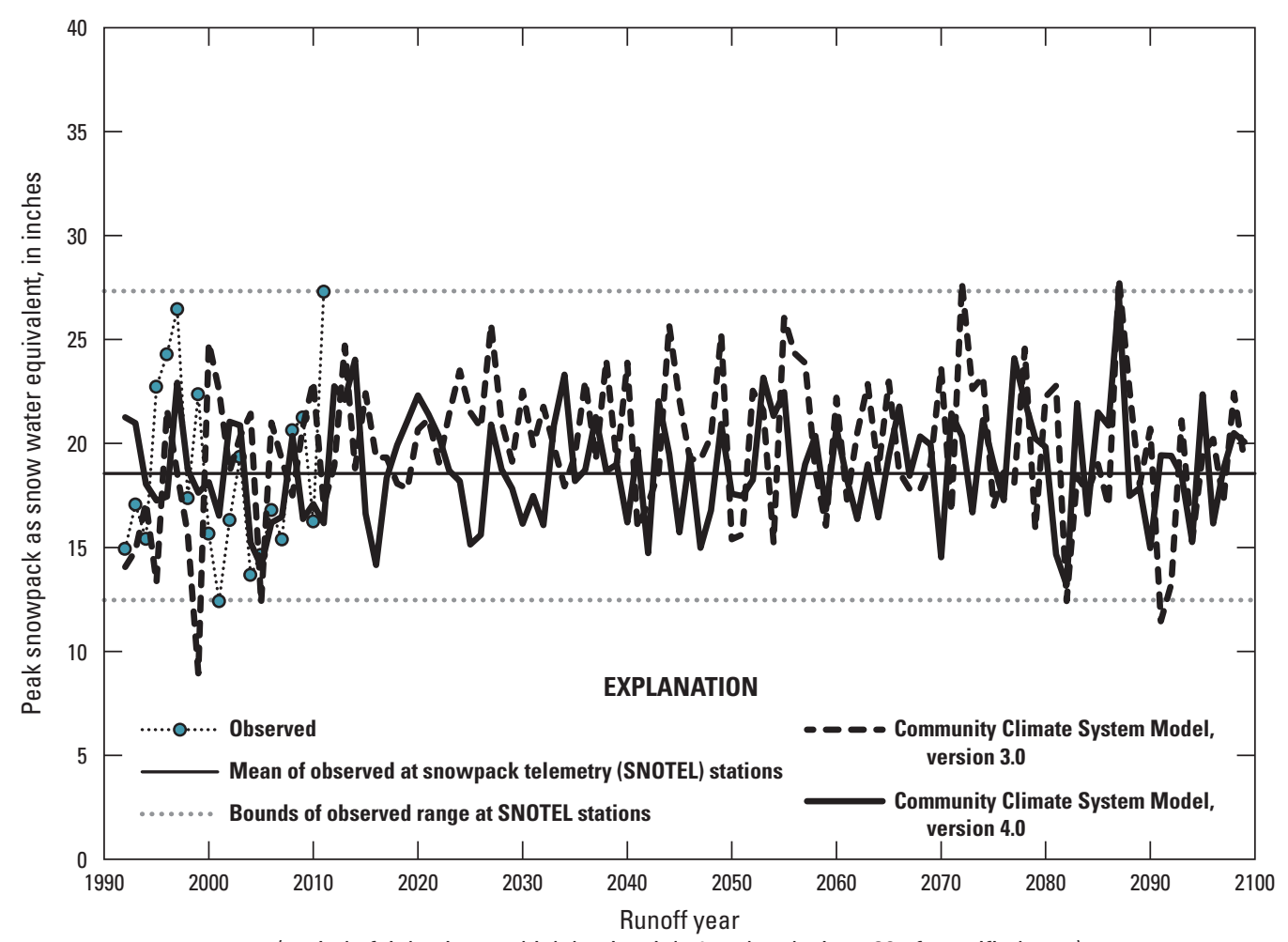

(period of July-June, which begins July 1 and ends June 30 of specified year)

Figure 14. Projections of peak snowpack for runoff years 1992-2099 for the lower Lake Sakakawea watershed. The Community Climate System Model, version 3.0 assumes the A2 emission scenario and version 4.0 assumes representative concentration pathway 8.5 . 


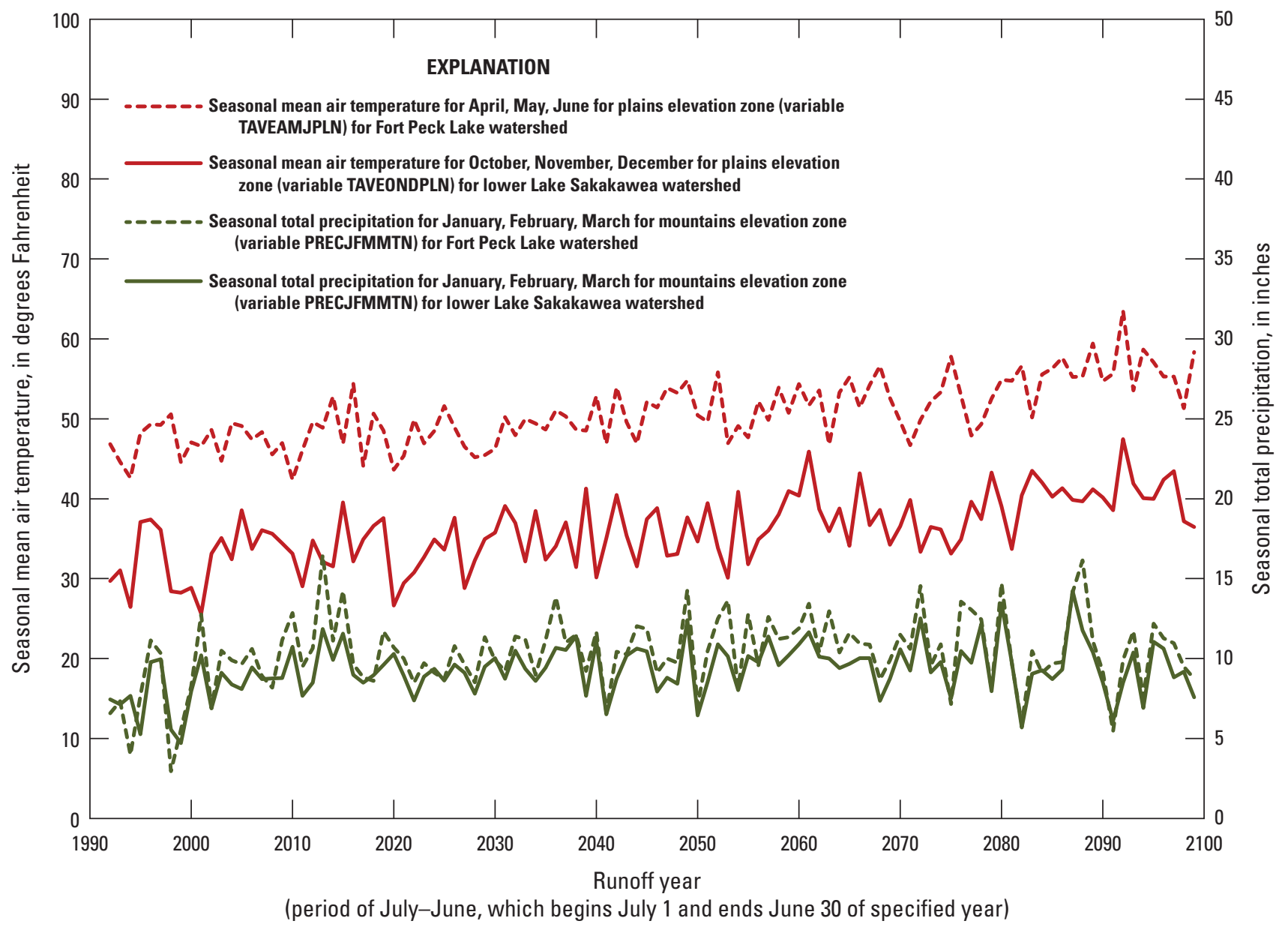

Figure 15. Projected regressor variables for air temperature and precipitation for the plains elevation zone and mountains elevation zones for selected seasons.

runoff is computed on the basis of records at a single station. Projections of May-July runoff included projected peak snowpack as a regressor variable.

Stepwise regression selected 29 and 26 regressor variables, out of 37 available (table 2), for the Fort Peck Lake and lower Lake Sakakawea watershed transfer functions, respectively. The incremental change in multiple $R^{2}$ with addition of variables was used to reduce the number of variables computed by stepwise regression to five for the Fort Peck Lake watershed and to four for the lower Lake Sakakawea watershed (table 12). The change in multiple $R^{2}$ values with the addition of regressor variables is shown in figure 16, and the resulting transfer function had multiple $\mathrm{R}^{2}$ values of 0.94 and 0.95 for the Fort Peck Lake and lower Lake Sakakawea watersheds, respectively. Regressor variables and associated coefficients for the transfer functions for both watersheds have the following common regressors:

- peak snowpack,

- precipitation in AMJ for the plains elevation range, and

- reference evapotranspiration for JAS for the foothills.
In summary, peak snowpack in the mountains was an important regressor variable, but regressor variables for the plains and foothill zones were also important. In particular, precipitation in the later part of the runoff season (AMJ) was an important regressor variable.

\section{Modern (1992-2011) May-July Runoff}

May-July runoff for the Fort Peck Lake and lower Lake Sakakawea watersheds, and the Lake Sakakawea watershed (both watersheds combined), was computed for runoff years 1992-2011 using calibration and validation regressor variables computed from HCN and SNOTEL station records (figs. 17-19). Plots of relations between computed May-July runoff and observed May-July runoff show a close correspondence for predictions computed on the basis of both calibration and validation datasets (figs. 20 and 21, respectively) for the Fort Peck Lake and lower Lake Sakakawea watersheds; however, the May-July runoff for the lower Lake Sakakawea watershed was slightly overestimated on the order of about 5 percent by the transfer function. Means of computed and 
Table 11. Mean number of years within a 10-year moving window, rounded off to the nearest integer, for which regressor variables representing air temperature and precipitation were outside of the range used for calibration of transfer functions.

[A runoff year is the period July-June (begins July 1 and ends June 30 of specified year). Air temperature regressors are means for April, May, June, and for October, November, December for the plains elevation zone. Precipitation regressors are means for January, February, March, and for October, November, December for the foothills and mountains elevation zones. CCSM3, Community Climate System Model, version 3.0; CCSM4, Community Climate System Model, version 4.0]

\begin{tabular}{|c|c|c|c|c|c|c|c|c|}
\hline \multirow{2}{*}{$\begin{array}{c}\text { 10-year window } \\
\text { ending in runoff } \\
\text { year }\end{array}$} & \multicolumn{4}{|c|}{ Air-temperature regressors } & \multicolumn{4}{|c|}{ Precipitation regressors } \\
\hline & \multicolumn{2}{|c|}{$\begin{array}{c}\text { Fort Peck Lake } \\
\text { watershed }\end{array}$} & \multicolumn{2}{|c|}{$\begin{array}{c}\text { Lower Lake Sakakawea } \\
\text { watershed }\end{array}$} & \multicolumn{2}{|c|}{ Fort Peck Lake watershed } & \multicolumn{2}{|c|}{$\begin{array}{c}\text { Lower Lake Sakakawea } \\
\text { watershed }\end{array}$} \\
\hline 2021 & 4 & 2 & 3 & 2 & 2 & 1 & 0 & 0 \\
\hline 2022 & 2 & 2 & 3 & 2 & 2 & 0 & 0 & 0 \\
\hline 2025 & 2 & 1 & 2 & 2 & 1 & 0 & 0 & 0 \\
\hline 2026 & 2 & 1 & 2 & 2 & 1 & 0 & 0 & 0 \\
\hline 2027 & 2 & 2 & 2 & 2 & 1 & 0 & 0 & 0 \\
\hline 2028 & 2 & 2 & 2 & 2 & 1 & 0 & 0 & 0 \\
\hline 2032 & 2 & 2 & 2 & 2 & 1 & 1 & 0 & 0 \\
\hline 2033 & 2 & 2 & 2 & 2 & 1 & 1 & 0 & 0 \\
\hline 2034 & 2 & 2 & 2 & 1 & 1 & 1 & 0 & 0 \\
\hline 2035 & 2 & 2 & 2 & 1 & 1 & 1 & 0 & 0 \\
\hline 2036 & 2 & 2 & 2 & 1 & 2 & 1 & 0 & 0 \\
\hline 2037 & 2 & 2 & 3 & 1 & 2 & 1 & 0 & 0 \\
\hline 2038 & 2 & 2 & 3 & 1 & 2 & 1 & 0 & 0 \\
\hline 2039 & 2 & 2 & 3 & 2 & 2 & 1 & 0 & 0 \\
\hline 2040 & 2 & 2 & 4 & 1 & 2 & 1 & 0 & 0 \\
\hline 2047 & 3 & 2 & 4 & 1 & 2 & 1 & 0 & 0 \\
\hline 2048 & 4 & 3 & 5 & 2 & 2 & 1 & 0 & 0 \\
\hline 2049 & 4 & 3 & 5 & 2 & 2 & 1 & 1 & 0 \\
\hline 2050 & 4 & 3 & 5 & 2 & 2 & 1 & 1 & 0 \\
\hline 2051 & 4 & 3 & 5 & 3 & 2 & 1 & 1 & 0 \\
\hline 2052 & 4 & 3 & 5 & 2 & 2 & 1 & 1 & 0 \\
\hline 2053 & 4 & 3 & 4 & 3 & 3 & 0 & 1 & 0 \\
\hline 2054 & 4 & 4 & 5 & 4 & 2 & 1 & 1 & 0 \\
\hline 2055 & 4 & 4 & 4 & 4 & 2 & 1 & 1 & 0 \\
\hline 2056 & 4 & 4 & 4 & 5 & 3 & 1 & 1 & 0 \\
\hline 2057 & 3 & 4 & 4 & 5 & 3 & 1 & 1 & 0 \\
\hline 2058 & 3 & 3 & 4 & 4 & 3 & 1 & 1 & 0 \\
\hline
\end{tabular}


Table 11. Mean number of years within a 10-year moving window, rounded off to the nearest integer, for which regressor variables representing air temperature and precipitation were outside of the range used for calibration of transfer functions.-Continued

\begin{tabular}{|c|c|c|c|c|c|c|c|c|}
\hline \multirow{2}{*}{$\begin{array}{c}\text { 10-year window } \\
\text { ending in runoff } \\
\text { year }\end{array}$} & \multicolumn{4}{|c|}{ Air-temperature regressors } & \multicolumn{4}{|c|}{ Precipitation regressors } \\
\hline & \multicolumn{2}{|c|}{$\begin{array}{c}\text { Fort Peck Lake } \\
\text { watershed }\end{array}$} & \multicolumn{2}{|c|}{$\begin{array}{c}\text { Lower Lake Sakakawea } \\
\text { watershed }\end{array}$} & \multicolumn{2}{|c|}{ Fort Peck Lake watershed } & \multicolumn{2}{|c|}{$\begin{array}{c}\text { Lower Lake Sakakawea } \\
\text { watershed }\end{array}$} \\
\hline 2059 & 3 & 4 & 4 & 5 & 3 & 1 & 1 & 0 \\
\hline 2060 & 4 & 5 & 5 & 6 & 4 & 1 & 1 & 0 \\
\hline 2063 & 5 & 6 & 5 & 6 & 4 & 1 & 1 & 0 \\
\hline 2064 & 6 & 7 & 5 & 5 & 4 & 1 & 1 & 0 \\
\hline 2065 & 6 & 7 & 6 & 5 & 4 & 1 & 1 & 0 \\
\hline 2066 & 7 & 7 & 6 & 6 & 3 & 1 & 1 & 0 \\
\hline 2070 & 7 & 8 & 5 & 6 & 2 & 1 & 1 & 0 \\
\hline 2071 & 7 & 8 & 5 & 6 & 2 & 1 & 0 & 0 \\
\hline 2072 & 7 & 7 & 5 & 6 & 2 & 1 & 1 & 0 \\
\hline 2073 & 7 & 7 & 5 & 6 & 2 & 1 & 1 & 0 \\
\hline 2074 & 6 & 6 & 5 & 6 & 2 & 2 & 1 & 0 \\
\hline 2075 & 6 & 6 & 5 & 6 & 1 & 1 & 1 & 0 \\
\hline 2076 & 6 & 6 & 5 & 5 & 2 & 1 & 1 & 0 \\
\hline 2077 & 6 & 6 & 5 & 6 & 2 & 2 & 1 & 1 \\
\hline 2078 & 6 & 6 & 4 & 6 & 3 & 2 & 1 & 1 \\
\hline 2085 & 7 & 8 & 8 & 9 & 2 & 2 & 1 & 1 \\
\hline 2086 & 8 & 9 & 8 & 9 & 2 & 2 & 1 & 1 \\
\hline 2087 & 8 & 9 & 9 & 9 & 2 & 2 & 2 & 1 \\
\hline 2088 & 8 & 9 & 10 & 10 & 2 & 2 & 1 & 1 \\
\hline 2089 & 8 & 9 & 10 & 10 & 2 & 2 & 1 & 1 \\
\hline 2090 & 9 & 10 & 10 & 10 & 1 & 2 & 1 & 1 \\
\hline 2091 & 8 & 10 & 10 & 10 & 1 & 2 & 1 & 1 \\
\hline 2092 & 8 & 10 & 10 & 10 & 1 & 1 & 1 & 1 \\
\hline 2093 & 9 & 10 & 10 & 10 & 2 & 1 & 1 & 1 \\
\hline 2094 & 9 & 10 & 10 & 10 & 2 & 1 & 1 & 1 \\
\hline 2095 & 9 & 10 & 10 & 10 & 2 & 1 & 1 & 1 \\
\hline 2096 & 9 & 10 & 10 & 10 & 2 & 1 & 1 & 1 \\
\hline 2097 & 9 & 10 & 10 & 10 & 2 & 0 & 0 & 1 \\
\hline 2098 & 9 & 9 & 9 & 9 & 1 & 0 & 0 & 1 \\
\hline 2099 & 9 & 9 & 9 & 9 & 1 & 0 & 0 & 1 \\
\hline
\end{tabular}


Table 12. Coefficients of May-July runoff transfer functions for the Fort Peck Lake and lower Lake Sakakawea watersheds.

[All variables were significant at the 0.001 probability. --, not applicable]

\begin{tabular}{|c|c|c|c|}
\hline \multicolumn{2}{|c|}{ Fort Peck Lake watershed } & \multicolumn{2}{|c|}{ Lower Lake Sakakawea watershed } \\
\hline \multicolumn{2}{|c|}{ Regression equation intercept $=\mathbf{3 . 0 8 6}$} & \multicolumn{2}{|c|}{ Regression equation intercept $=3.953$} \\
\hline Variable $^{\mathrm{a}, \mathrm{b}}$ & Coefficient & Variable $^{\mathrm{a}, \mathrm{b}}$ & Coefficient \\
\hline PEAKSWE & 0.029 & PEAKSWE & 0.030 \\
\hline PRECAMJPLN & 0.061 & PRECAMJPLN & 0.053 \\
\hline EVAPJASFTH & -0.053 & TAVEAMJPLN & -0.018 \\
\hline PRECONDPLN & 0.030 & EVAPJASFTH & -0.011 \\
\hline EVAPONDPLN & -0.082 & -- & -- \\
\hline
\end{tabular}

aVariable names are expressed in captial letters using Courier type font.

${ }^{\mathrm{b}}$ These variable names are composed of letter combinations designating various abbreviations as defined in table 2 . Abbreviations applicable to the variables in this table follow: PEAKSWE, Peak snowpack, as snow water equivalent, in inches; PREC, total precipitation; EVAP, total reference evaporation; TAVE, mean temperature; AMJ, April, May, June; JAS, July, August, September; OND, October, November, December; AMJ, April, May, June; PLN, plains elevation zone; FTH, foothills elevation zone.

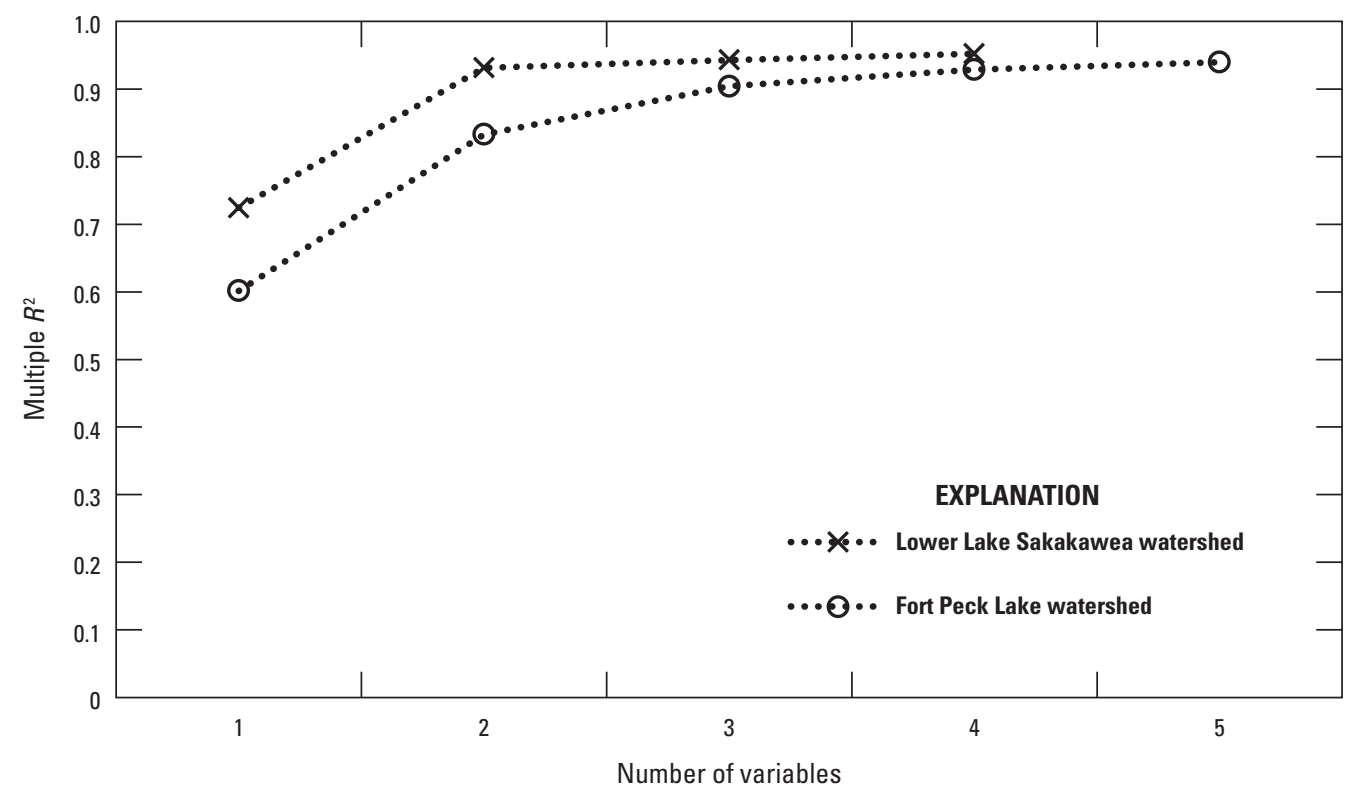

Figure 16. Incremental increase in multiple coefficient of determination $\left(R^{2}\right)$ values with addition of regressor variables in table 12.

observed May-July runoff were not significantly different on the basis of a paired Student's t-test on the calibration and validation datasets (table 13).

May-July runoff also was computed for 1992-2011 using regressor variables computed from CCSM3 and CCSM4 output for all watersheds (figs. 22-24). As previously described, regressed mean May-July runoff for 1992-2011 computed on the basis of CCSM3 and CCSM4 will not precisely match that observed for each year, but the goal is to match the observed hydroclimatology. Student's t-test indicate no significant difference at a 0.05 probability between means of observed
May-July runoff and regressed May-July runoff from CCSM3 and CCSM4 output for both watersheds, and of combined May-July runoff for both watersheds (table 13). May-July runoff for 1992-2011 computed from CCSM3 output generally falls within the range of that observed (figs. 22-24), but minimum values have a negative bias (lower than observed), and the standard deviation for CCSM3 output for the Fort Peck Lake watershed is greater than that observed (table 14). May-July runoff for 1992-2011 computed from CCSM4 output falls within the range of that observed (figs. 22-24); however, the standard deviation for CCSM4 output is less 
than that observed (table 14). For these reasons, it might be expected that May-July runoff projected for 2012-99 from CCSM4 output might be more conservatively estimated than that from CCSM3 output particularly for simulation years with lower projected flows.

\section{Projected (2012-99) May-July Runoff}

May-July runoff was projected for 2012-99 by applying the transfer function to regressor variables computed from CCSM3 and CCSM4 output. Trends for 2012-99 were tested for significance using the Kendall's tau nonparametric test (Kendall, 1938) at a 0.05 probability. Projected May-July runoff for 2012-99 for the Fort Peck Lake, lower Lake Sakakawea, and Lake Sakakawea (combined watersheds of Fort Peck Lake and lower Lake Sakakawea) watersheds indicates significant downward trends as regressed from CCSM3 and CCSM4 output; however, in contrast, when the time series is limited to 2012-60, no trends in May-July runoff were significant for the three watersheds. Variance in May-July runoff for 2012-99 for the Fort Peck watershed and the Lake Sakakawea watershed (combined watersheds) significantly decreased as regressed from CCSM4 output computed on the basis of the
Breusch-Pagan test (Breusch and Pagan, 1979). There were no significant changes in variance when analyses were limited to 2012-60.

Trends in projected May-July runoff for 2012-99 for the Fort Peck Lake watershed regressed from CCSM3 and CCSM4 output resulted in runoff that was less than the minimum observed particularly in records subsequent to simulation year 2060. For 2060-99 (39 years), regressed May-July runoff from CCSM3 and CCSM4 output was less than the minimum observed for 13 and 21 years, respectively. This contrasts with the 1 and 5 years that were less than the minimum May-July runoff in 2012-60 as regressed from CCSM3 and CCSM4 output, respectively; however, regressed May-July runoff for 2060-99 should be interpreted with caution; as described in the "Peak Snowpack" section, a caveat of the methodology is that regressor variables for 2060-99 commonly were outside of the range of calibration. For 2060-99, regressed runoff for the lower Lake Sakakawea watershed was less than the minimum May-July runoff observed for 11 and 8 years as regressed from CCSM3 and CCSM4 output, respectively. This contrasts with 1 year that was less than the minimum MayJuly runoff as regressed from CCSM3 and CCSM4 output for 2012-60.

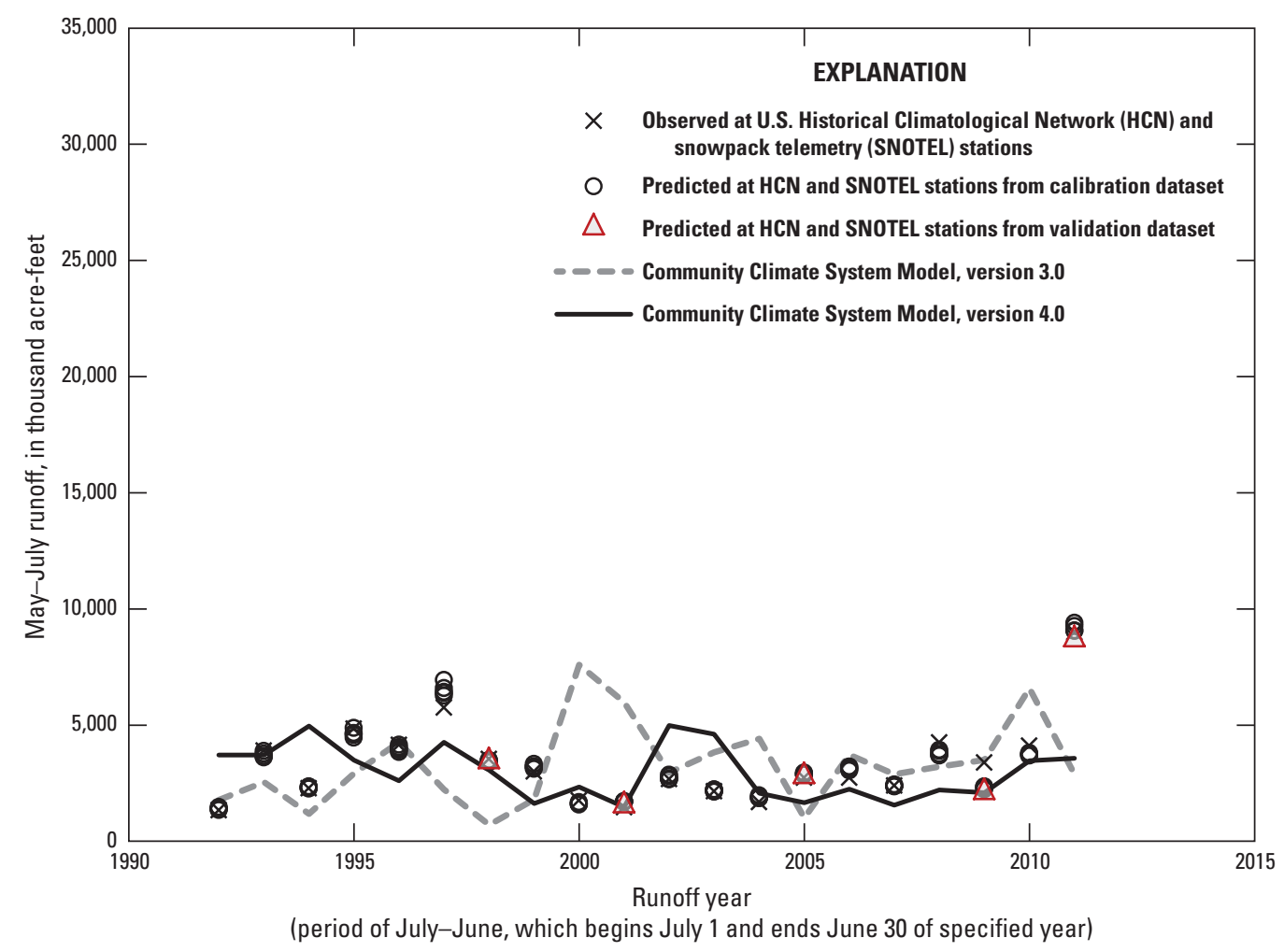

Figure 17. May-July runoff for runoff years 1992-2011 for the Fort Peck Lake watershed. Multiple calibration points for each runoff year are a product of the bootstrap method. 


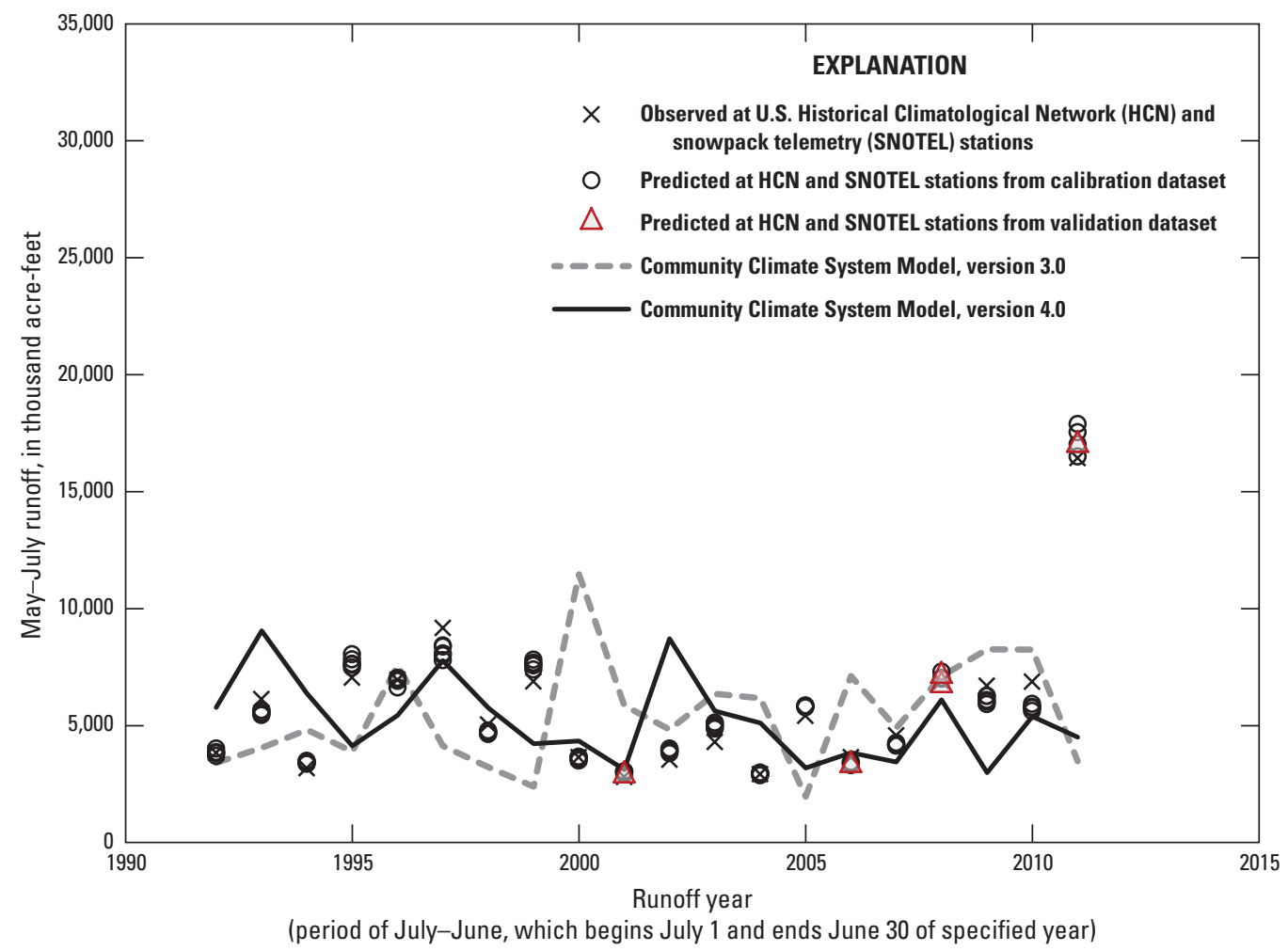

Figure 18. May-July runoff for runoff years 1992-2011 for the lower Lake Sakakawea watershed. Multiple calibration points for each runoff year are a product of the bootstrap method.

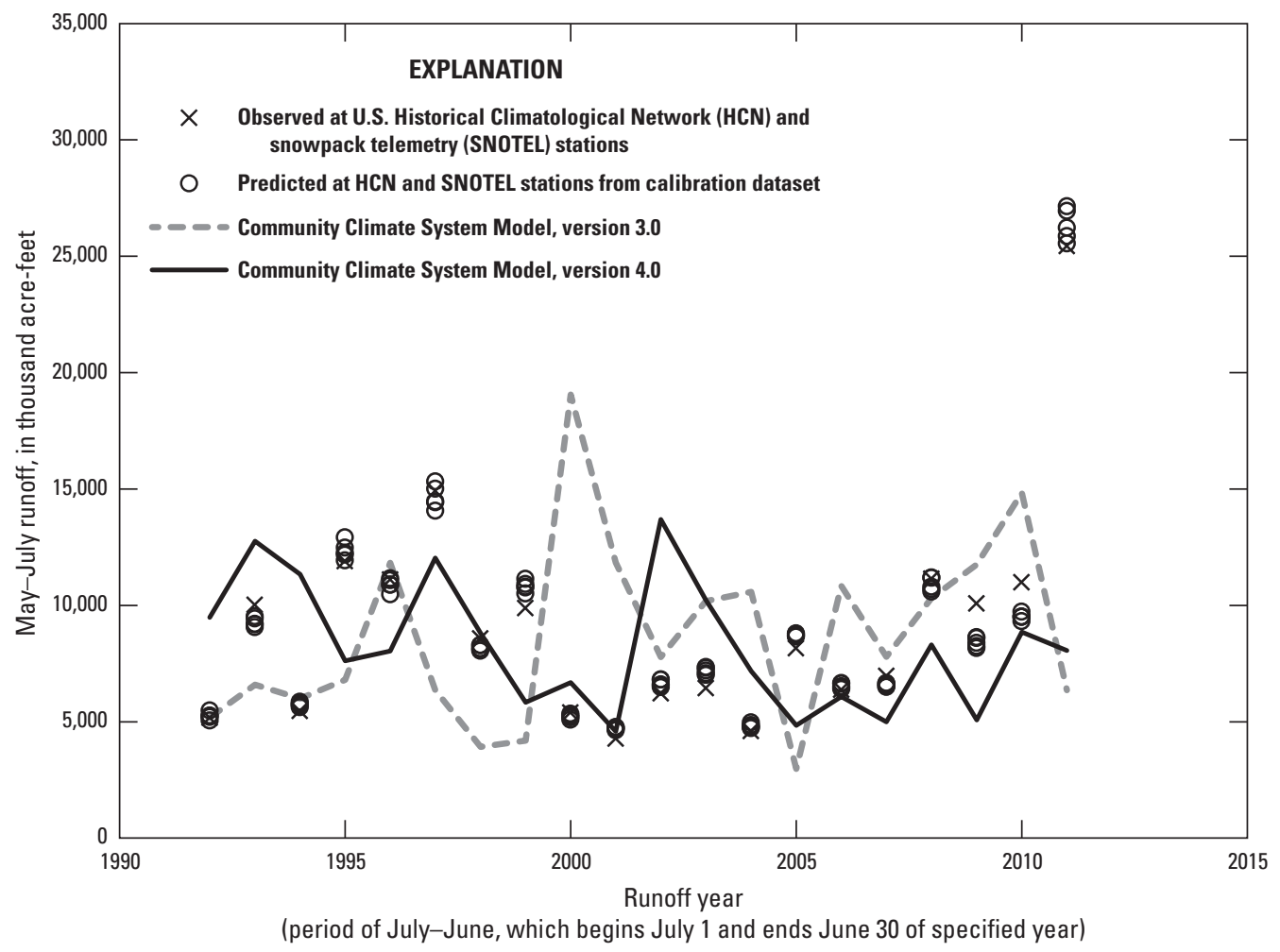

Figure 19. May-July runoff for runoff years 1992-2011 for the Lake Sakakawea watershed (Fort Peck Lake and lower Lake Sakakawea watersheds combined). Multiple calibration points for each runoff year are a product of the bootstrap method. 


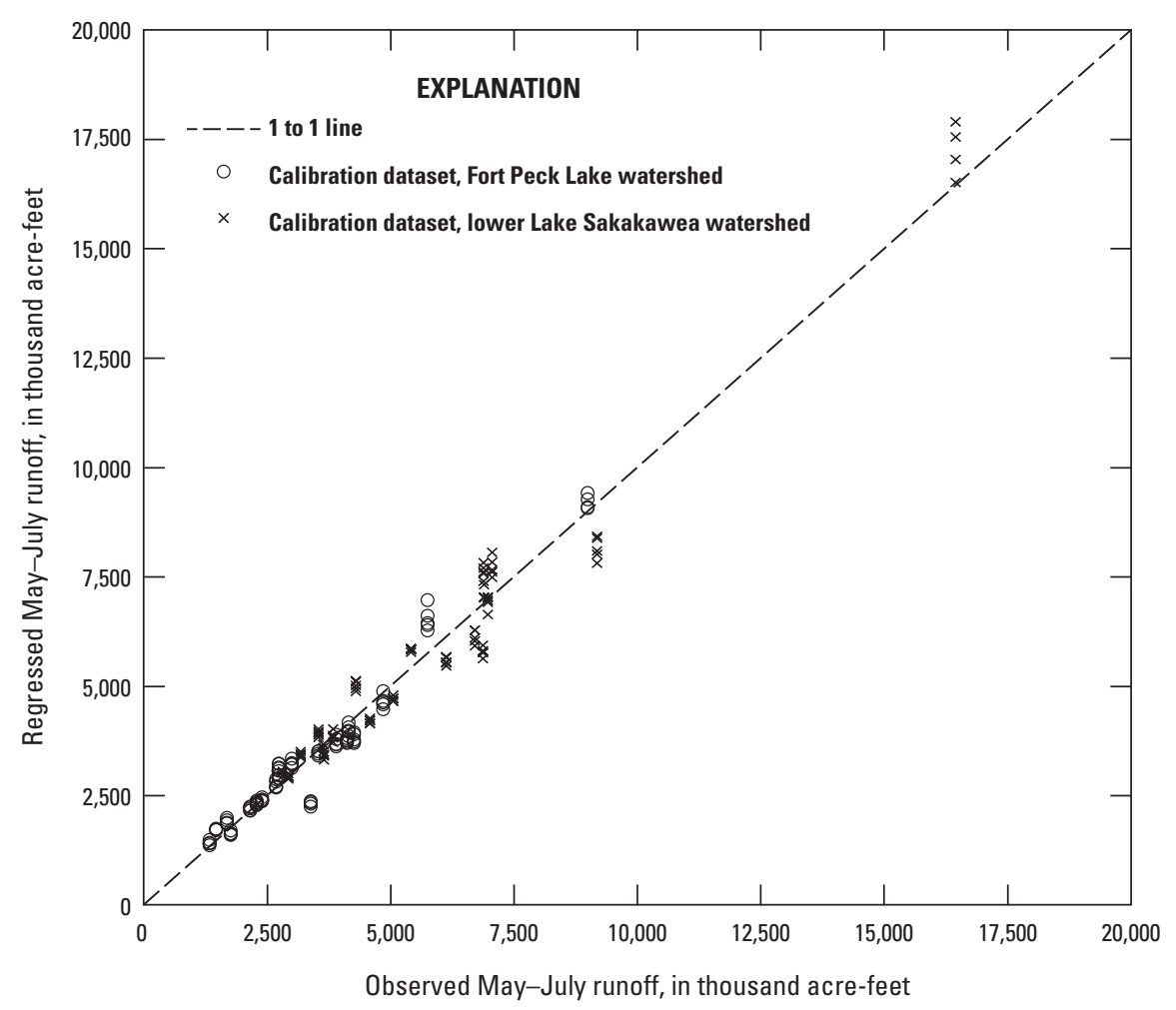

Figure 20. Relation between regressed and observed May-July runoff used for calibration, Fort Peck Lake and lower Lake Sakakawea watersheds.

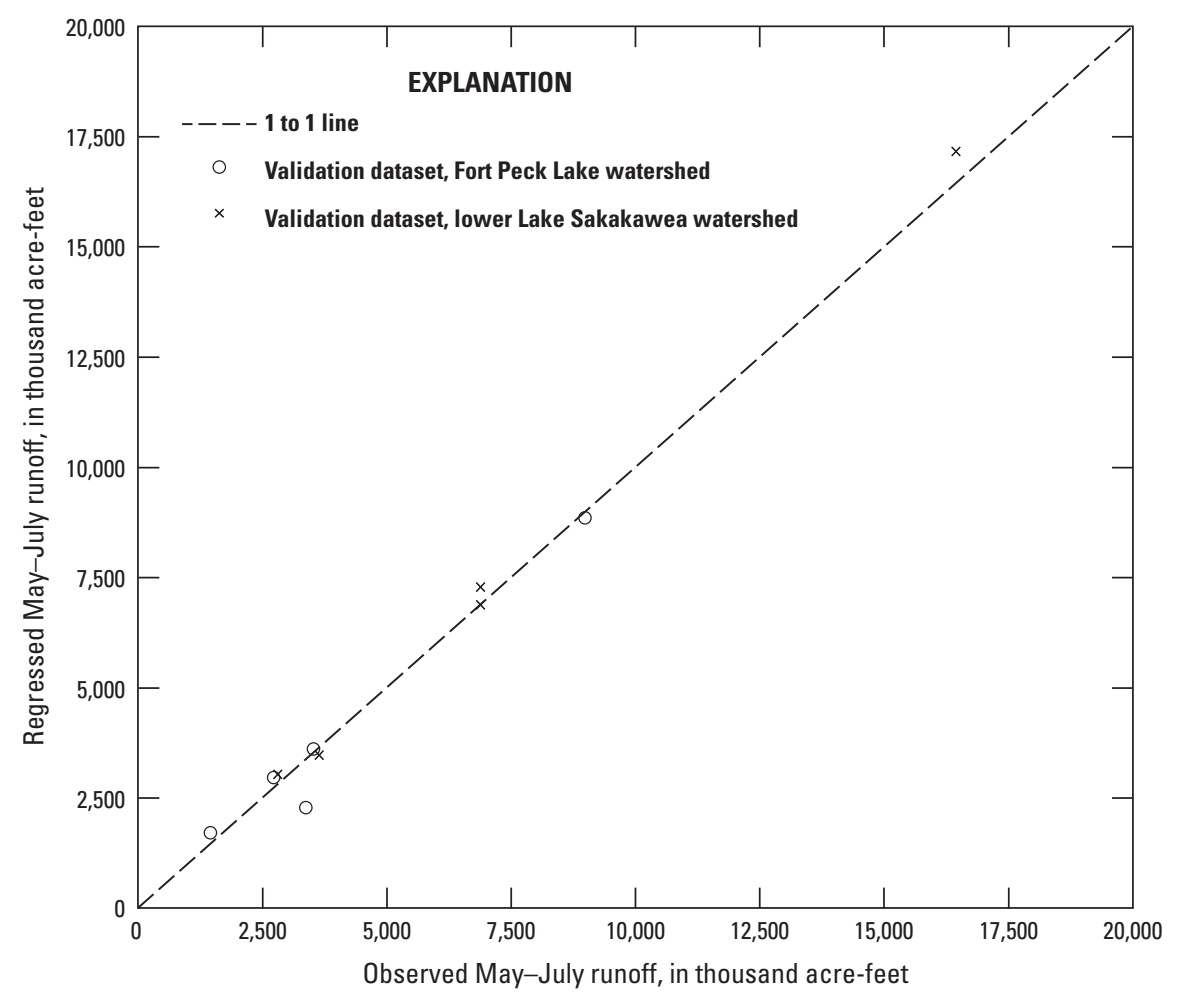

Figure 21. Relation between regressed and observed May-July runoff used for validation, Fort Peck Lake and lower Lake Sakakawea watersheds. 
Table 13. Results of Student's t-tests for the null hypothesis that observed and regressed May-July runoff have equal means.

[Means were not significantly different at the 0.05 probability for all tests. Student's t-tests for validation and calibration datasets are paired, and for Community Climate System Model, versions 3 and 4, are two-tailed, and two-samples with unequal variance. CCSM3, regressed from transfer function applied to the Community Climate System Model, version 3.0 output; CCSM4, regressed from transfer function applied to the Community Climate System Model, version 4.0]

\begin{tabular}{lccccc}
\hline \multirow{2}{*}{ Dataset } & \multicolumn{2}{c}{ Fort Peck Lake watershed } & & \multicolumn{2}{c}{ Lower Lake Sakakawea watershed } \\
\cline { 2 - 3 } \cline { 5 - 6 } & t-value & Probability & & t-value & Probability \\
\hline Calibration & 0.192 & 0.848 & & 0.152 & 0.880 \\
Validation & 0.656 & 0.548 & & -1.384 & 0.239 \\
CCSM3 & 0.110 & 0.913 & & 0.392 & 0.698 \\
CCSM4 & 0.794 & 0.433 & & 0.706 & 0.486 \\
\hline
\end{tabular}

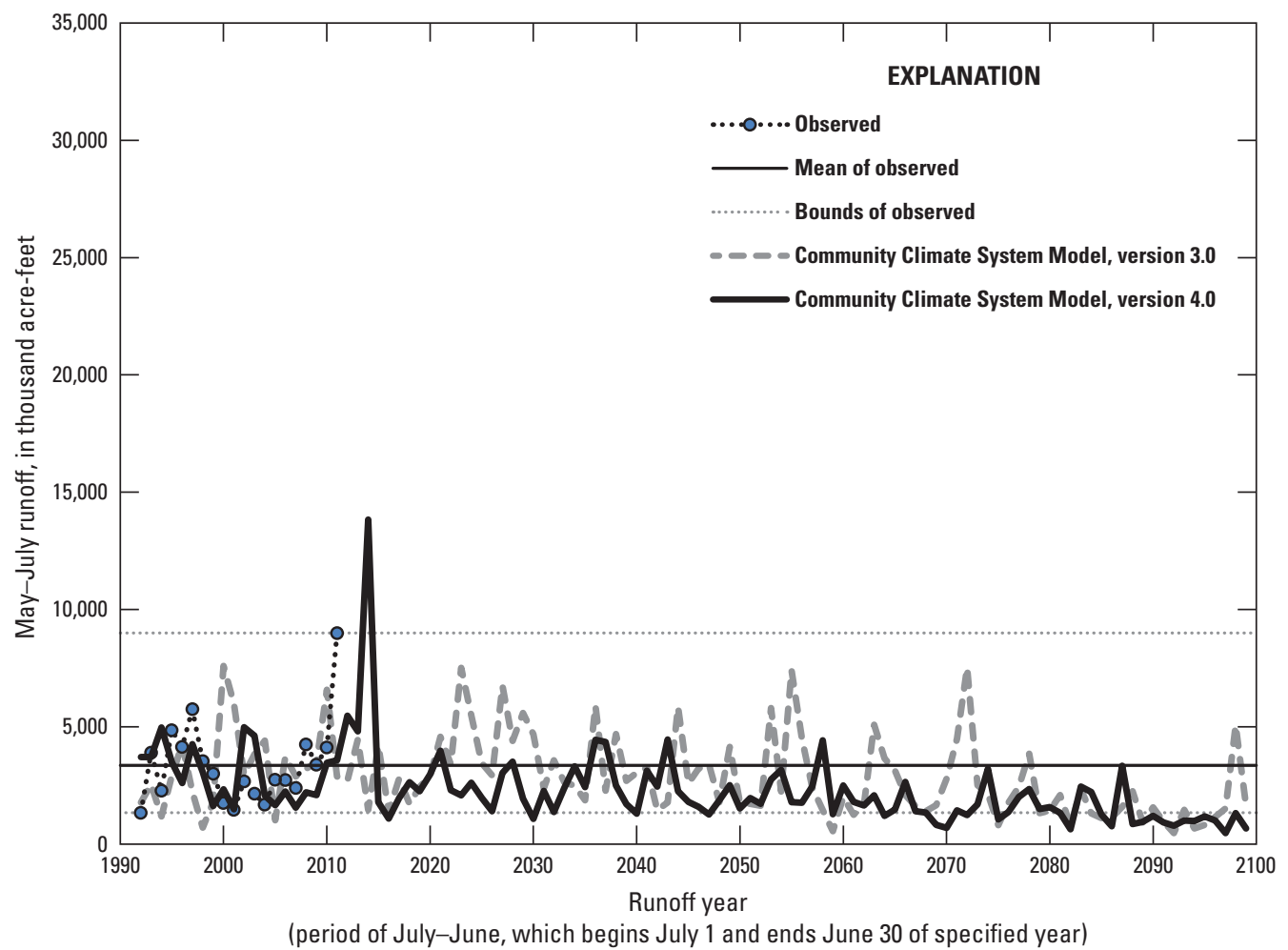

Figure 22. Projections of May-July runoff for runoff years 1992-2099 for the Fort Peck Lake watershed. The Community Climate System Model, version 3.0 assumes the A2 emission scenario and version 4.0 assumes representative concentration pathway 8.5 . 


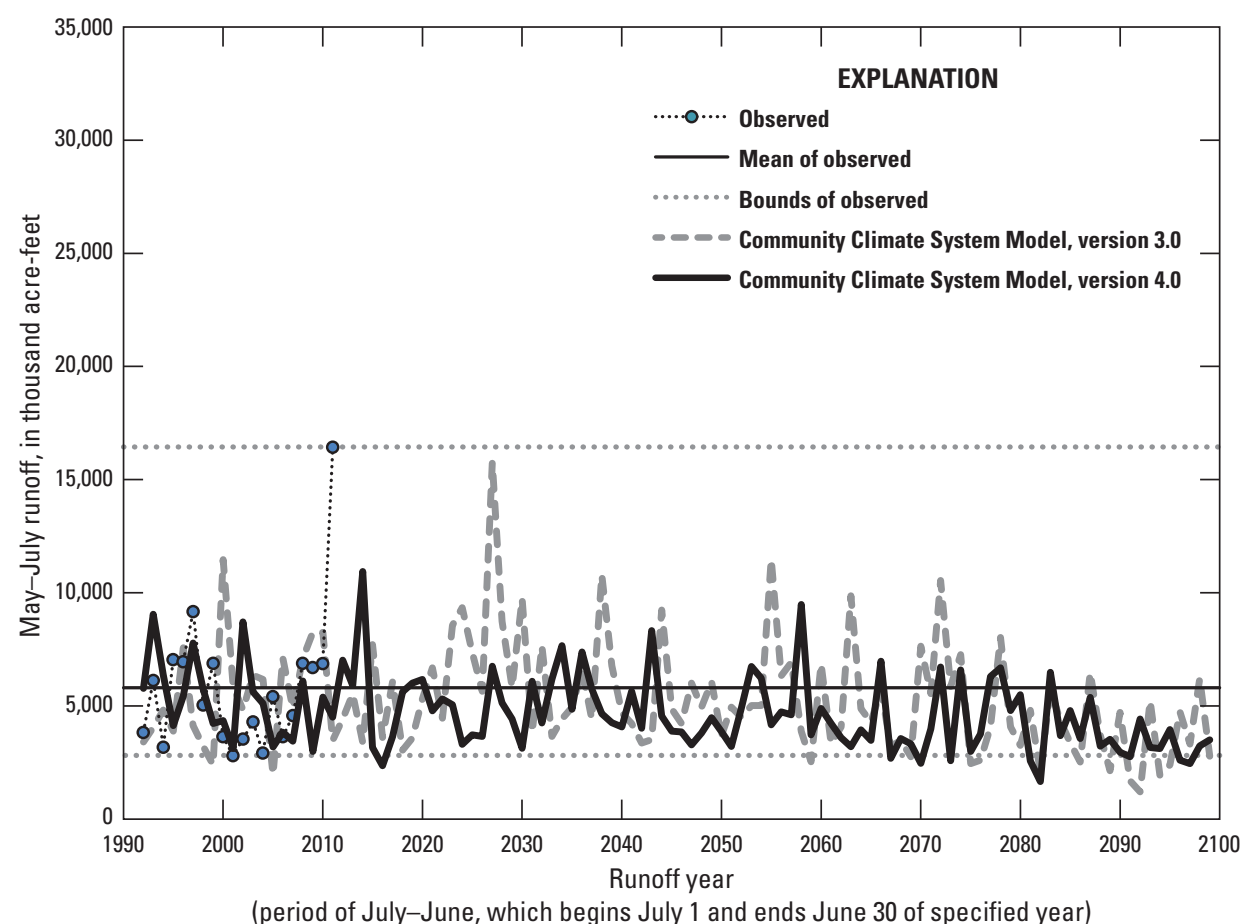

Figure 23. Projections of May-July runoff for runoff years 1992-2099 for the lower Lake Sakakawea watershed. The Community Climate System Model, version 3.0 assumes the A2 emission scenario and version 4.0 assumes representative concentration pathway 8.5 .

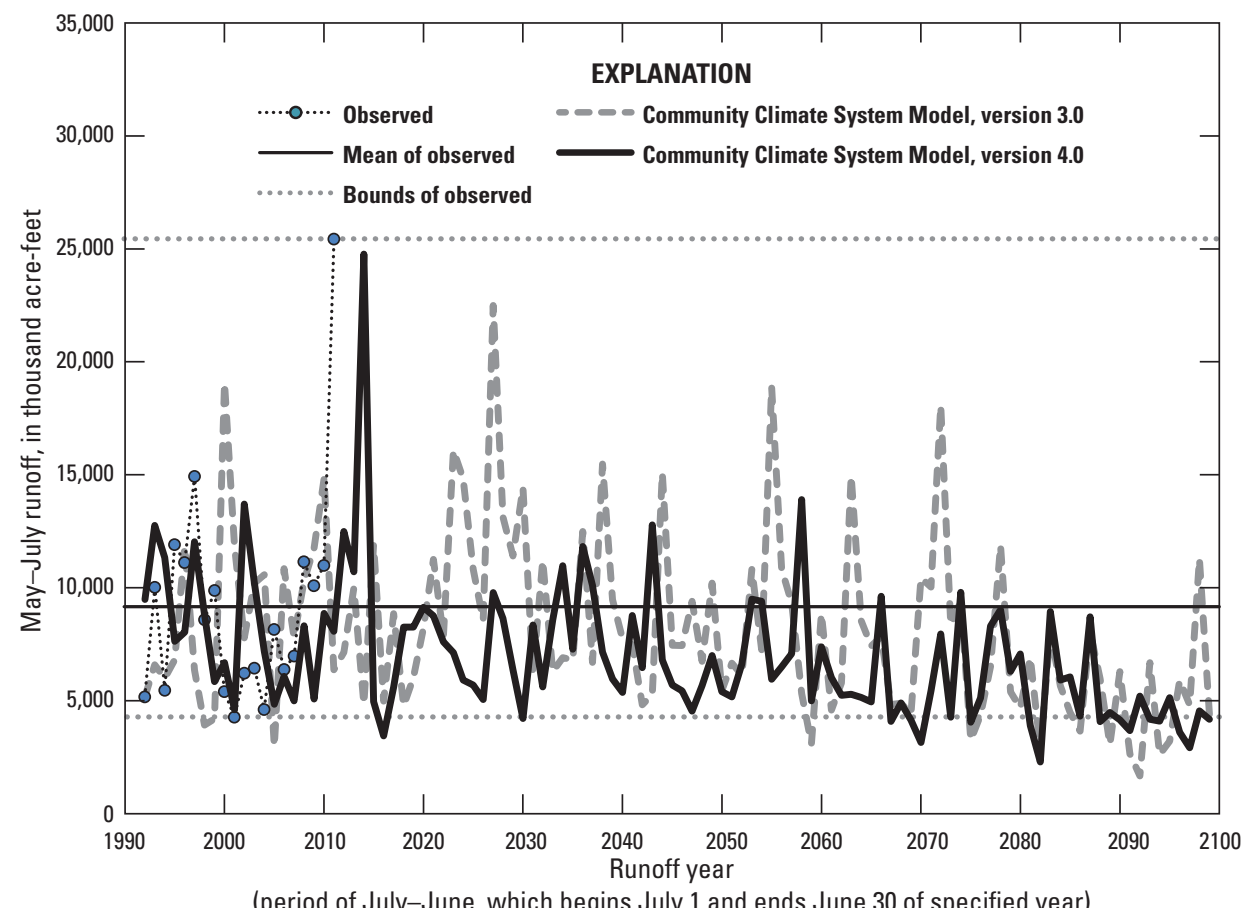

Figure 24. Projections of May-July runoff for runoff years 1992-2099 for the Lake Sakakawea watershed (Fort Peck Lake and lower Lake Sakakawea watersheds combined). The Community Climate System Model, version 3.0 assumes the A2 emission scenario and version 4.0 assumes representative concentration pathway 8.5. 
Table 14. Summary statistics for observed and regressed May-July runoff for runoff years 1992-2011.

[A runoff year is the period of July-June (begins July 1 and ends June 30 of specified year). CCSM3, regressed from the Community Climate System Model, version 3.0 output; CCSM4, regressed from the Community Climate System Model, version 4.0 output]

\begin{tabular}{|c|c|c|c|c|c|c|c|c|c|}
\hline \multirow{3}{*}{ Statistic } & \multicolumn{9}{|c|}{ May-July runoff for 1992-2011, in thousand acre-feet } \\
\hline & \multicolumn{3}{|c|}{ Fort Peck Lake watershed } & \multicolumn{3}{|c|}{ Lower Lake Sakakawea watershed } & \multicolumn{3}{|c|}{ Lake Sakakawea watershed } \\
\hline & Observed & CCSM3 & CCSM4 & Observed & CCSM3 & CCSM4 & Observed & CCSM3 & CCSM4 \\
\hline Mean & 3,361 & 3,299 & 2,985 & 5,802 & 5,464 & 5,244 & 9,163 & 8,762 & 8,229 \\
\hline Maximum & 8,999 & 7,596 & 4,982 & 16,441 & 11,467 & 9,055 & 25,440 & 19,062 & 13,698 \\
\hline Minimum & 1,340 & 699 & 1,479 & 2,812 & 1,966 & 2,986 & 4,278 & 2,979 & 4,594 \\
\hline Standard deviation & 1,777 & 1,814 & 1,156 & 3,068 & 2,353 & 1,754 & 4,797 & 3,994 & 2,717 \\
\hline
\end{tabular}

\section{Projected Power Production and Runoff Magnitudes}

Fort Peck and Garrison Dams have had a mean annual discharge of $10,200 \mathrm{ft}^{3} / \mathrm{s}$ and $23,000 \mathrm{ft}^{3} / \mathrm{s}$, respectively, available to supply reservoir water for power production. For comparison to May-July runoff, these means correspond to 7,382 and 16,645 thousand acre-ft per year for Fort Peck and Garrison Dams, respectively. Adjusting annual total runoff to that for a 91-day period results in 1,860 and 4,195 thousand acre-ft per 91 days for Fort Peck and Garrison Dams, respectively. May-July runoff would be expected to be greater than these adjusted values of runoff given that much of the annual flow occurs in this period. May-July runoff for the Fort Peck Lake watershed was projected to periodically fall below 1,840 thousand acre-ft for a total of 11 and 15 years for 2012-60 (22 and 31 percent of years), and for a total of 24 and 31 years for 2061-99 (60 and 78 percent of years), as regressed from CCSM3 and CCSM4 output, respectively; therefore, projected trends in runoff indicate power production from the Fort Peck Dam watershed might be periodically affected by low runoff in upcoming decades. The Garrison Dam, which impounds Lake Sakakawea (combined runoff from Fort Peck Lake and lower Lake Sakakawea watersheds), was projected to have mean annual discharges that fall below $23,000 \mathrm{ft}^{3} / \mathrm{s}$ for only 1 year for 2012-60, and 8 and 15 years (20 and 35 percent of years) for 2060-99 as regressed from CCSM3 and CCSM4 output, respectively; therefore, projected downward trends in May-July runoff are not indicated to affect power production from the Garrison Dam watershed as strongly as indicated for the Fort Peck Dam.

May-July runoff on the order of magnitude of the peak of record observed in 2011 (25,400 thousand acre-ft) were projected for the Lake Sakakawea watershed (two watersheds combined). Regressed May-July runoff for the Lake Sakakawea was projected to include one event of this magnitude as regressed from CCSM3 output (22,500 thousand acre- $\mathrm{ft}$ in simulation year 2027) and one event of this magnitude as regressed from CCSM4 output (24,800 thousand acre-ft in simulation year 2014) (fig. 24). These events will be referred to as event 1 and event 2, respectively. It is important to clarify that these results do not predict events of this magnitude in these actual calendar years. Event 1 was a product of high May-July runoff from the Fort Peck Lake watershed, whereas event 2 was a product of high May-July runoff from the lower Lake Sakakawea watershed. Both simulation years with these events have high peak snowpack and high precipitation in AMJ for the plains elevation zone (figs. 25 and 26), which are the two regressors with strongest loadings in the transfer functions. An event of the magnitude of the 2011 observed event was due to regressors that reflected high peak snowpack in the mountains followed by a season of high precipitation in the plains; therefore, plains precipitation (which might fall as snow in AMJ) is indicated to be an important factor in large runoff events. 


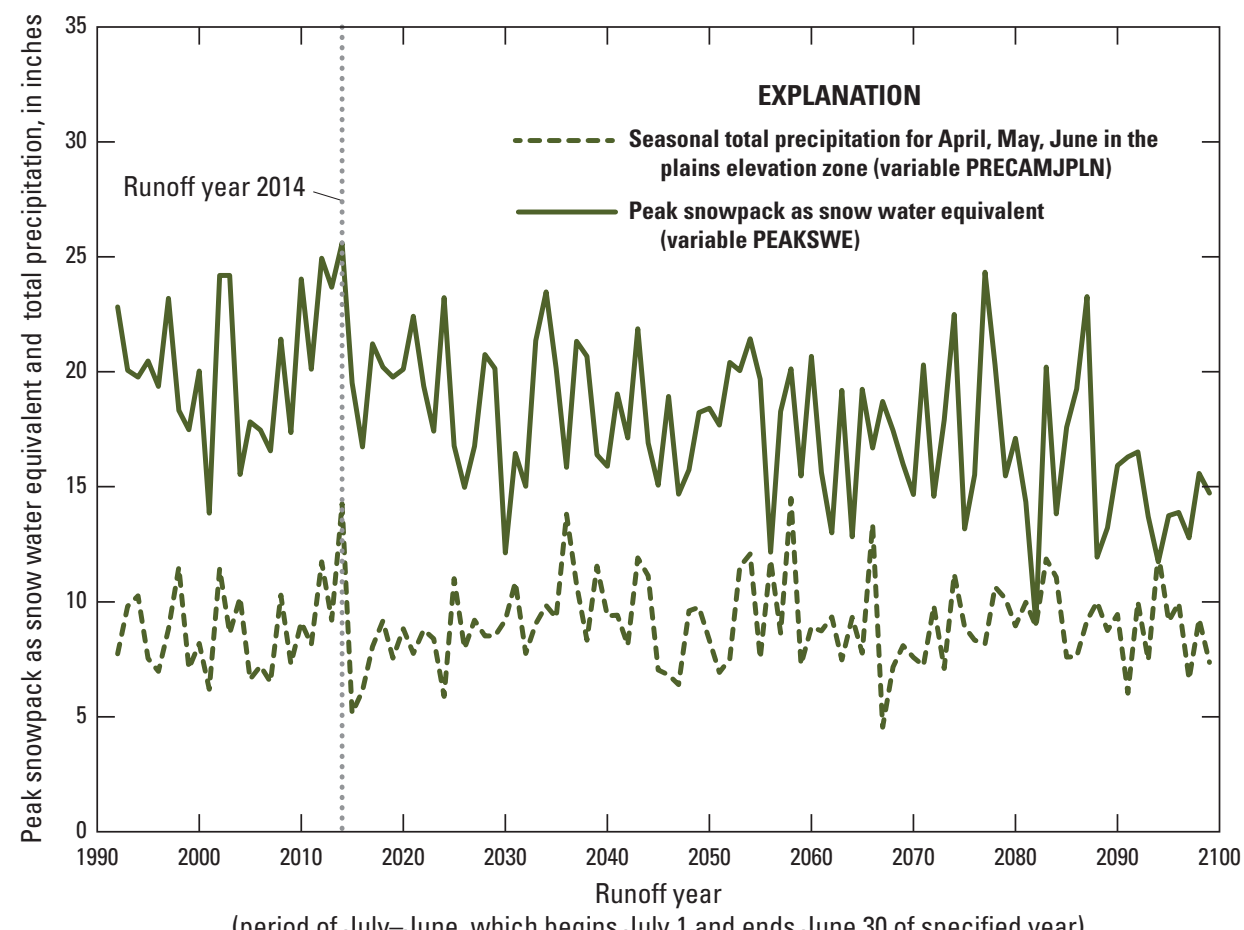

(period of July-June, which begins July 1 and ends June 30 of specified year)

Figure 25. April, May, June precipitation for the plains elevation zone and peak snowpack in the Fort Peck Lake watershed (Fort Peck Lake and lower Lake Sakakawea watersheds combined) as interpolated from Community Climate System Model, version 4.0 output.

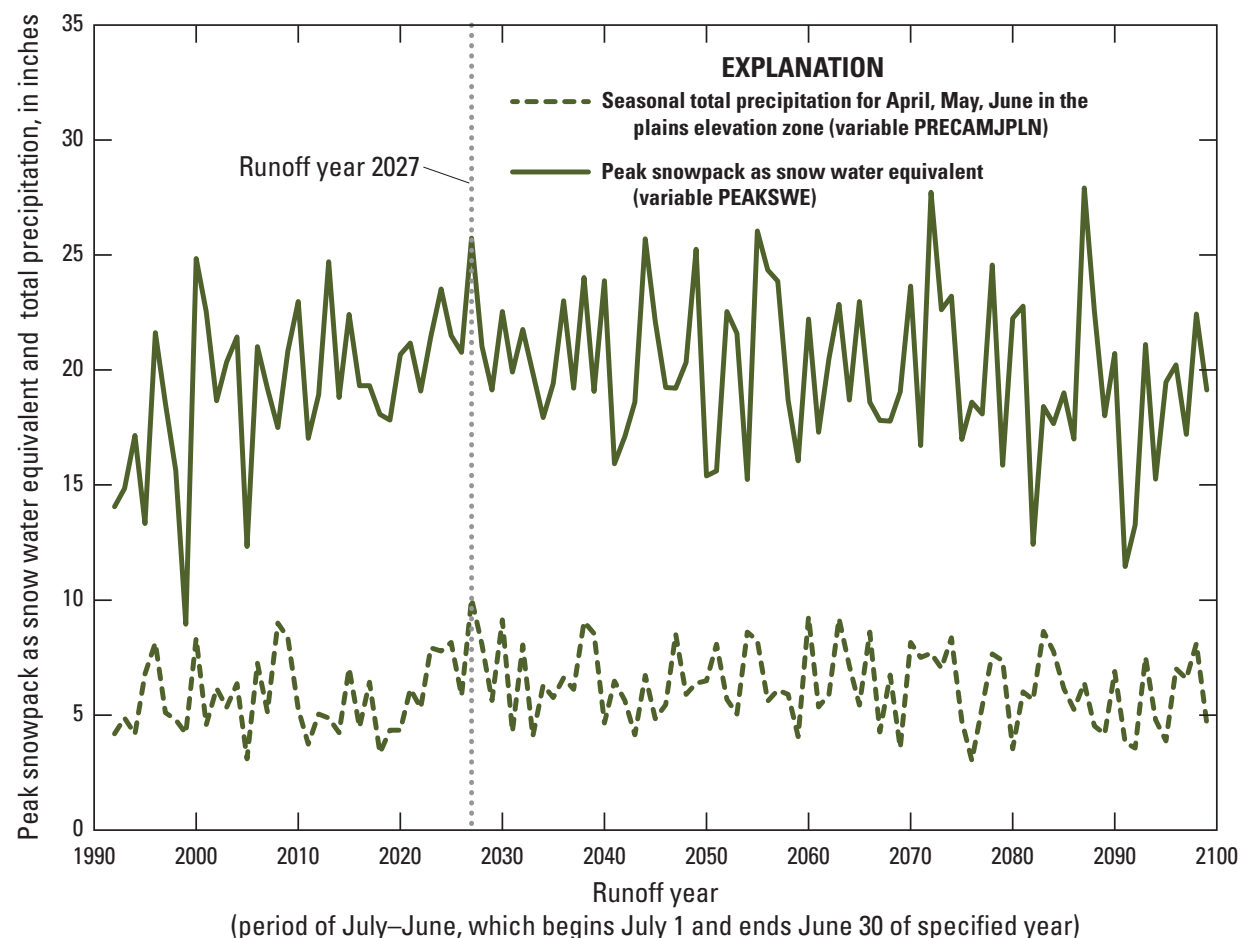

Figure 26. April, May, June precipitation for the plains elevation zone and peak snowpack in the lower Lake Sakakawea watershed as interpolated from Community Climate System Model, version 3.0 output. 


\section{Summary}

Mountain snowpack is an important contributor to runoff in the Upper Missouri River Basin; for example, high amounts of winter and spring precipitation in the mountains and plains in 2010-2011 were associated with the peak runoff of record in the Upper Missouri River Basin. The U.S. Army Corps of Engineers completed a pilot research study in collaboration with the U.S. Geological Survey, National Weather Service, U.S. Department of Agriculture Natural Resources Conservation Service, and South Dakota State University to help assess if mountain snowpack and runoff was changing because of changes in climate. The U.S. Geological Survey, in cooperation with the Climate Preparedness and Resilience Community of Practice of the U.S. Army Corps of Engineers, completed a followup study to simulate modern (1992-2011) and projected (2012-99) mountain peak snowpack and May-July runoff into Fort Peck Lake and Lake Sakakawea in the upper part of the Missouri River Basin. Additional objectives of this study were to determine if May-July runoff projected for 2012-99 might produce runoff events on the magnitude of the 2011 flood, develop insights to processes associated with such events, and to determine if projected May-July runoff might drop below the magnitude required to maintain power generation at hydroelectric dams.

Simulations were based on the calibration of transfer functions using multiple linear regression and stepwise regression techniques. Regressor (explanatory) variables represented seasonal air temperature and precipitation. Regressor variables for May-July runoff also included peak snowpack and seasonal total reference evapotranspiration. The calibration period was 1992-2011 because of the limitations of available records from 107 weather stations. Two watersheds were considered: (1) the Fort Peck Lake watershed and (2) the lower Lake Sakakawea watershed, which was defined as the part of the Lake Sakakawea watershed below Fort Peck Dam. Peak snowpack and May-July runoff were projected for 2012-99 on the basis of air temperature and precipitation interpolated from output from Community Climate System Model, version 3.0 (CCSM3) and version 4.0 (CCSM4) to the locations of weather and snow telemetry stations, and bias corrected to station monthly means.

Projected peak snowpack for 2012-99 for the Fort Peck Lake watershed indicated significant downward trends in regressed peak snowpack computed on the basis of CCSM3 and CCSM4 output. In contrast, projected peak snowpack for 2012-99 for the lower Lake Sakakawea watershed indicated no trends in regressed peak snowpack computed on the basis of CCSM3 and CCSM4 output. Projected May-July runoff for 2012-99 for the Fort Peck Lake, lower Lake Sakakawea, and Lake Sakakawea (combined watersheds of Fork Peck Lake and lower Lake Sakakawea) watersheds regressed on the basis of CCSM3 and CCSM4 output had significant downward trends for 2012-99; however, when time series were limited to 2012-60, trends were not significant.
Projected trends in runoff indicate power production from the Fort Peck Dam might be periodically affected by low runoff in upcoming decades. Regressed May-July runoff for 2012-99 for the two watersheds combined (Lake Sakakawea watershed) was projected to have events of the magnitude of the observed flood of 2011: 24,800 thousand acre-feet in simulation year 2014 based on CCSM4 output, and 22,500 thousand acre-feet in simulation year 2027 based on CCSM3 output. Analysis of regressor variables indicated that high peak snowpack and high precipitation for AMJ in the foothills combined in these simulation years to produce peaks in either the Fort Peck Lake watershed or lower Lake Sakakawea watershed, which translated into peak runoff on the order of magnitude of the 2011 flood for the Lake Sakakawea watershed (combined watersheds). A caveat of the statistical approach used for this study was that simulations for 2060-99 are commonly based on regressor variables that fall outside of the range used for calibration; therefore, results for 2060-99 were interpreted with caution.

\section{References Cited}

Adler, Joseph, 2010, R in a nutshell: Sebastopol, Calif., O’Reilly Media, Inc., 611 p.

Akaike, Hirotugu, 1974, A new look at the statistical model identification: IEEE Transactions on Automatic Control, v. 19, no. 6, p. 716-723. [Also available at http://dx.doi. org/10.1109/TAC.1974.1100705.]

Bradley, R.S., 1999, Paleoclimatology-Reconstructing climates of the Quaternary (2d ed.): New York, Academic Press, International Geophysics Series, v. 68, 613 p.

Brekke, L.D., White, Kathleen, Olsen, J.R., Townsley, Edwin, Williams, David, Hanbali, Fauwaz, Hennig, Chuck, Brown, Curt, Raff, David, and Wittler, Rod, 2011, Addressing climate change in long-term water resource planning and management-User needs for improving tools and information: Washington, U.S. Army Corps of Engineers Civil Works Technical Series CWTS-10-02, 132 p., accessed October 21, 2014, at http:/www.usbr.gov/climate/userneeds/ docs/LTdoc.pdf.

Breusch, T.S., and Pagan, A.R., 1979, A simple test for heteroscedasticity and random coefficient variation: Econometrica, Journal of the Econometric Society, v. 47, no. 5, p. 1287-1294. [Also available at http://dx.doi. org/10.2307/1911963.]

Commission for Environmental Cooperation, 1997, Ecological regions of North America-Toward a common perspective: Montreal, Canada, Commission for Environmental Cooperation. [Also available at http://www.cec.org/Page. asp?PageID=924\&ContentID=2336.] 
Daly, Christopher, Neilson, R.P., and Phillips, D.L., 1994, A statistical-topographic model for mapping climatological precipitation over mountainous terrain: Journal of Applied Meteorology, v. 33, no. 2, p. 140-158. [Also available at http://dx.doi.org/10.1175/1520-0450(1994)033<0140:AST $\mathrm{MFM}>2.0 . \mathrm{CO} ; 2$.

Daly, Christopher, Gibson, W.P., Taylor, G.H., Johnson, G.L., and Pasteris, Phillip, 2002, A knowledge-based approach to the statistical mapping of climate: Climatic Research, v. 22 , no. 2 , p. $99-113$. [Also available at http://dx.doi. org/10.3354/cr022099.]

Davis, J.C., 2002, Statistics and data analysis in geology (3d ed.): New York, John Wiley and Sons, 638 p.

Draper, Norman, and Smith, Harry, 1981, Applied regression analysis ( $2 \mathrm{~d}$ ed.): New York, John Wiley and Sons, 709 p.

Efron, B., 1979, Bootstrap methods-Another look at the jackknife: The Annals of Statistics, v. 7, no. 1, p. 1-26. [Also available at https://projecteuclid.org/download/pdf_1/euclid. aos/1176344552.]

Fenneman, N.M., 1931, Physiography of the western United States: New York, McGraw Hill, 534 p. plus map.

Garstka, W.U., 1964, Snow and snow survey, in Chow, V.T., ed., Handbook of applied hydrology: New York, McGrawHill Book Company, p. 10-1-10-57.

Gent, P.R., Danabasoglu, Gokham, Donner, L.J., Holland, M.M., Hunke, E.C., Jayne, S.R., Lawrence, D.M., Neale, R.B., Rasch, P.J., Vertenstein, Mariana, Worley, P.H., Yang, Zong-Liang., and Zhang, Minghua, 2011, The Community Climate System Model version 4: Journal of Climate, v. 24 , no. 19 , p. 4973-4991. [Also available at http://dx.doi. org/10.1175/2011JCLI4083.1.]

Glahn, H.R., 1968, Canonical correlation and its relationship to discriminant analysis and multiple regression: Journal of the Atmospheric Sciences, v. 25, no. 1, p. 23-31. [Also available at http://dx.doi.org/10.1175/15200469(1968)025<0023:CCAIRT>2.0.CO;2]

Grode, K., Doan, W., Stamm, K., Mayes Boustead, B., Rossi, S., Perkins, T., and Todey, D., 2014, Climate change evaluation - Upper Missouri River Basin mountain snowpackAccumulation and runoff: Washington, D.C., U.S. Army Corps of Engineers, 204 p., accessed June 9, 2016, at http:// www.corpsclimate.us/docs/Climate_Change_Evaluation_ Upper_Missouri_Mountain_Snowpack_July_2014_Final. pdf.

Hargreaves, G.H., and Samani, Z.A., 1985, Reference crop evapotranspiration from temperature: Applied Engineering in Agriculture, v. 1, no. 2, p. 96-99. [Also available at http:// dx.doi.org/10.13031/2013.26773.]
Hirsch, R.H., 2011, A perspective on nonstationarity and water management: Journal of the American Water Resources Association, v. 47, no. 3, p. 436-446. [Also available at http://dx.doi.org/10.1111/j.1752-1688.2011.00539.x.]

Hirsch, R.H., and Ryberg, K.R., 2011, Has the magnitude of flood across the USA changed with global $\mathrm{CO}_{2}$ levels?: Hydrological Sciences Journal, v. 57, no. 1, p. 1-9. [Also available at http://dx.doi.org/10.1080/02626667.2011.6218 95.]

Hoerling, Martin, Schubert, S., Mo, K., AghaKouchak, A., Berbery, H., Dong, J., Kumar, A., Lakshmi, V., Leung, R., Li, J., Liang, X., Luo, L., Lyon, B., Miskus, D., Quan, X., Seager, R., Sorooshian, S., Wang, H., Xia, Y., and Zeng, N., 2013, An interpretation of the origins of the 2012 central Great Plains drought: National Oceanic and Atmospheric Administration, Climate Program Office, NOAA Drought Task Force Narrative Team Assessment Report, 44 p., accessed October 21, 2014, at ftp://ftp.oar.noaa.gov/CPO/ pdf/mapp/reports/2012-Drought-Interpretation-final.web041113.pdf.

Hotelling, Harold, 1936, Relations between two sets of variates: Biometrika, v. 28, no. 3-4, p. 321-377. [Also available at http://dx.doi.org/10.1093/biomet/28.3-4.321.]

Irmak, Suat, and Haman, D.Z., 2003, EvapotranspirationPotential or reference?: University of Florida, Institute of Food and Agricultural Sciences Series ABE 343, 2 p., accessed January 29, 2015, at http://edis.ifas.ufl.edu/ pdffiles/AE/AE25600.pdf.

Kammerer, J.C., 1990, Largest rivers in the United States: U.S. Geological Survey Open-File Report 87-242, 2 p., accessed September 24, 2014, at http://pubs.usgs.gov/ of/1987/ofr87-242/.

Kendall, M.G., 1938, A new measure of rank correlation: Biometrika, v. 30, no. 1-2, p. 81-93. [Also available at http://dx.doi.org/10.1093/biomet/30.1-2.81.]

Mearns, L.O., Gutowski, William, Jones, Richard, Leung, Ruby, McGinnis, Seth, Nunes, Ana, and Qian, Yun, 2009, A regional climate change assessment program for North America: EOS, v. 90, no. 36, p. 311-312. [Also available at http://dx.doi.org/10.1029/2009EO360002.]

Milly, P.C.D., Betancourt, Julio, Falkenmark, Malin, Hirsch, R.M., Kundzewicz, Z.W., Lettenmaier, D.P., and Stouffer, R.J., 2008, Stationarity is dead-Whither water management?: Science, v. 319, no. 5863, p. 573-574. [Also available at http://dx.doi.org/10.1126/science.1151915.]

Nakićenović, Nebojsa, and Swart, Rob, eds., 2000, Emission scenarios-A special report of Working Group III of the Intergovernmental Panel on Climate Change: Cambridge, England, Cambridge University Press, 570 p., accessed June 22, 2015, at http://www.ipcc.ch/ipccreports/sres/ emission/index.php?idp $=0$. 
National Oceanic and Atmospheric Administration, 2012, The Missouri/Souris River floods of May-August 2011: U.S. National Oceanic and Atmospheric Administration National Weather Service, 68 p., 5 appendixes, accessed September 24, 2014, at http://www.nws.noaa.gov/os/ assessments/pdfs/Missouri_floods11.pdf.

Natural Resources Conservation Service, 2014, SNOTEL data collection network fact sheet: accessed August 25, 2014, at http://www.wcc.nrcs.usda.gov/factpub/sntlfct1.html.

Norton, P.A., Anderson, M.T., and Stamm, J.F., 2014, Trends in annual, seasonal, and monthly streamflow characteristics at 227 streamgages in the Missouri River watershed, water years 1960-2011: U.S. Geological Survey Scientific Investigations Report 2014-5053, 128 p., accessed August 21, 2014, at http://dx.doi.org/10.3133/sir20145053.

Oak Ridge National Laboratory, 2014, Data access-Longterm daily and monthly climate records from stations across the contiguous United States: U.S. Department of Energy, Office of Science, Carbon Dioxide Information Analysis Center, Oak Ridge National Laboratory, accessed October 23, 2014, at http://cdiac.ornl.gov/epubs/ndp/ushcn/ access.html.

Ott, R.L, 1993, An introduction to statistical methods and data analysis (4th ed.): Belmont, Calif., Duxbury Press, 1,051 p.

Peel, M.C., Finlayson, B.L., and McMahon, T.A., 2007, Updated world map of the Köppen-Giger climate classification: Hydrology and Earth System Sciences, v. 11, p. 1633-2007. [Also available at http://dx.doi.org/10.5194/ hess-11-1633-2007.]

Snyder, R.L, and Eching, S., 2002, Penman-Monteith daily (24-hour) reference evapotranspiration equations for estimating ETo, ETr, and HS ETo with daily data: Davis, Calif., Regents of the University of California, accessed October 21, 2014, at http://biomet.ucdavis.edu/ Evapotranspiration/PMdayXLS/PMdayDoc.pdf.

Svoboda, Mark, LeComte, Doug, Hayes, Mike, Heim, Richard, Gleason, Karin, Angel, Jim, Rippey, Brad, Tinker, Rich, Palecki, Mike, Stooksbury, David, Miskus, David, and Stephens, Scott, 2002, The drought monitor: Bulletin of the American Meteorological Society, v. 83, no. 8, p. 1181-1190. [Also available at http://dx.doi. org/10.1175/1520-0477(2002)083<1181:TDM >2.3.CO;2.]

U.S. Army Corps of Engineers, 2006, Missouri River Mainstem Reservoir System-Master Water control manualMissouri River Basin: U.S. Army Corps of Engineers, Northwestern Division, [variously paged], accessed August 20, 2014, at http://www.nwd-mr.usace.army.mil/rcc/ reports/mmanual/MasterManual.pdf.
U.S. Army Corps of Engineers, 2012, Climate change adaptation pilots: U.S. Army Corps of Engineers, 35 p., accessed October 21, 2014, at http://www.corpsclimate.us/docs/ RCC_Pilots_Sept_2012_highres.pdf.

U.S. Army Corps of Engineers, 2013a, Missouri River Mainstem System-2013-2014 annual operating plan: U.S. Army Corps of Engineers, Northwestern Division, accessed March 18, 2015, at http://www.nwd-mr.usace.army.mil/rcc/ reports/pdfs/finalAOP2013-2014.pdf.

U.S. Army Corps of Engineers, 2013b, Hydrologic statistics technical report: Omaha, Nebr., U.S. Army Corps of Engineers, Northwestern Division, Missouri River Basin Water Management Division, accessed March 18, 2015, at http://www.nwd-mr.usace.army.mil/rcc/reports/pdfs/ MRBWMTechReport-HydrologicStatistics_September2013. pdf.

U.S. Army Corps of Engineers, 2015, Water management information links-Monthly project statistics: U.S. Army Corps of Engineers, Northwestern Division, Missouri River Basin Water Management Division, accessed March 18, 2015, at http://www.nwd-mr.usace.army.mil/rcc/projdata/ projdata.html.

U.S. Geological Survey, 2014, USGS surface-water data for the Nation: U.S. Geological Survey National Water Information System, accessed August 25, 2014, at http:// waterdata.usgs.gov/nwis/sw.

Vuuren, D.P. van, Edmonds, Jae, Kainuma, Mikiko, Riahi, Keywan, Thomson, Allison, Hibbard, Kathy, Hurtt, G.C., Kram, Tom, Krey, Volker, Lamarque, Jean-Francois, Masui, Toshihiko, Meinshausen, Malte, Nakicenovic, Nebojsa, Smith, S.J., and Rose, S.K., 2011, The representative concentration pathways-An overview: Climatic Change, v. 109, no. 1-2, p. 5-31. [Also available at http://dx.doi. org/10.1007/s10584-011-0148-z.]

Vertenstein, Mariana, Craig, Tony, Henderson, Tom, Murphy, Sylvia, Carr, G.R., Jr., and Norton, Nancy, 2004, CCSM3.0 user's guide: Boulder, Colo., National Center for Atmospheric Research, Community Climate System Model, accessed August 24, 2014, at http://www.cesm.ucar.edu/ models/ccsm3.0/ccsm/doc/UsersGuide/UsersGuide.pdf.

Vertenstein, Mariana, Craig, Tony, Middleton, Adrianne, Feddema, Diane, and Fischer, Chris, 2013, CCSM4.0 user's guide: 126 p., accessed August 24, 2014, at http://www. cesm.ucar.edu/models/ccsm4.0/ccsm_doc/ug.pdf.

Vining, K.C., Chase, K.J., and Loss, G.R., 2013, General weather conditions and precipitation contributing to the 2011 flooding in the Mississippi River and Red River of the North Basins, December 2010 through July 2011: U.S. Geological Survey Professional Paper 1798-B, 22 p., accessed June 22, 2015, at http://pubs.usgs.gov/pp/1798b/. 

Appendixes 


\section{Appendix 1. Air Temperature and Precipitation at Stations}

This appendix contains links to digital data tables in text format (.txt) of monthly mean air temperature and total precipitation, and daily snow water equivalent (SWE) at the locations of U.S. Historical Climatology Network (HCN) and snowpack telemetry (SNOTEL) stations used in analyses in this report (see "Approach and Methods" section, table 1). The file "HCN_SNOTEL_data.zip" contains compressed files in two directories. The first directory is named "Daily" and contains daily SNOTEL data. The second directory is named "Monthly" and contains monthly means of daily mean air temperature and monthly precipitation at HCN and SNOTEL stations. Files named "README.txt" are in directories and provide additional information on file names and data formats.

\section{Appendix 2. Community Climate System Model Output}

This appendix describes the Community Climate System Model, version 3.0 (CCSM3) and version 4.0 (CCSM4) that were accessed for this study through the Earth System Grid data portal (https://www.earthsystemgrid.org/home.htm). The postprocessed atmospheric data for contemporary climate simulated by CCSM3 are available at https://www.earthsystemgrid.org/dataset/ucar.cgd.ccsm.b30.030e.html and for projected climate are available at https://www.earthsystemgrid.org/dataset/ucar.cgd.ccsm.b30.042e.html. Daily precipitation files accessed from these websites include the following:

- "b30.030e.cam2.h3.PRECC.1990-01-01_cat_1999-12-31.nc,"

- "b30.030e.cam2.h3.PRECL.1990-01-01_cat_1999-12-31.nc,"

- “b30.042e.cam2.h3.PRECC.2000-01-01_cat_2009-12-31.nc," and

- "b30.042e.cam2.h3.PRECL.2000-01-01_cat_2009-12-31.nc."

Output files for monthly mean air temperature are a set of files, one for each decade, starting sequentially from 1990-99 for air temperature with example file names formats as follows:

- "b30.030e.cam2.h0.TREFMNAV.1990-01_cat_1999-12.nc,"

- “b30.030e.cam2.h0.TREFMXAV.1990-01_cat_1999-12.nc," and

- "b30.030e.cam2.h0.TREFMAV.1990-01_cat_1999-12.nc."

Associated output files for projected air temperature have example filename formats (starting with the decade 2000-09 and ending with decade 2090-99):

- “b30.042e.cam2.h0.TREFMNAV.2000-01_cat_2009-12.nc," and

- "b30.042e.cam2.h0.TREFMXAV.2000-01_cat_2009-12.nc."

File names starting with "b30" indicate the CCSM3, the " 042 " indicates the A2 emissions scenario, and "cam2" indicates the Community Atmosphere Model output (as opposed to the ocean model part the CCSM3.) The variables PRECC and PRECL indicate convective precipitation and frontal (large-scale) precipitation, respectively; TREF is temperature at a 2-meter (6.6-ft) reference height; and MNAV and MXAV are the monthly means of daily minimum and maximum air temperature, respectively. The suffix "nc" refers to Network Common Data Form file format, which is supported by the University Corporation for Atmospheric Research (http://www.unidata.ucar.edu/software/netcdf).

The postprocessed atmospheric data for contemporary climate simulated by CCSM3 are available at

https://www.earthsystemgrid.org/dataset/ucar.cgd.ccsm4.b40.20th.track1.1deg.009.html

and for projected climate are available at

https://www.earthsystemgrid.org/dataset/ucar.cgd.ccsm4.b40.rcp8_5.1deg.002.html. 
The CCSM4 output files of daily precipitation and monthly air temperature files accessed include the following:

- "b40.20th.track1.1deg.009.cam2.h1.PRECC.185010101-20051231.nc,"

- "b40.20th.track1.1deg.009.cam2.h1.PRECL.185010101-20051231.nc,"

- "b40.20th.track1.1deg.009.cam2.h0.TREFMNAV.185001-200512.nc,"

- "b40.20th.track1.1deg.009.cam2.h0.TREFMXAV.185001-200512.nc,"

- "b40.rcp8_5.1deg.002.cam2.h1.PRECC.18500101-20051231.nc,"

- "b40.rcp8_5.1deg.002.cam2.h1.PRECL.18500101-20051231.nc,"

- "b40.rcp8_5.1deg.002.cam2.h0.TREFMNAV.18500101-20051231.nc," and

- "b40.rcp8_5.1deg.002.cam2.h0.TREFMXAV.18500101-20051231.nc."

File names starting with "b40" indicate the CCSM4, "20th" indicates the 20th century, but includes $1850-2005$, and "rcp8_5" is representative concentration pathway 8.5 watts per meter squared. File names are otherwise labelled similarly to CCSM3 file names.

\section{Appendix 3: Interpolated Community Climate System Model Output}

The Community Climate System Model, version 3.0 (CCSM3) and version 4.0 (CCSM4) output were interpolated to the location of U.S. Historical Climatology Network (HCN) and snowpack telemetry (SNOTEL) stations used in this study (see "Approach and Methods" section, table 1). The interpolation equation was a function of the inverse distance squared of a station to the surrounding four CCSM grid points. The file "interpolated_CCSM_output.zip" contains compressed files of interpolated CCSM3 and CCSM4 output. The file "README.txt" is in the archived directory and provides additional information on file names and formats used.

\section{Appendix 4: Bias-Corrected Community Climate System Model Output}

The Community Climate System Model, version 3.0 (CCSM3) and version 4.0 (CCSM4) output were bias corrected on the basis of U.S. Historical Climatology Network (HCN) and snowpack telemetry (SNOTEL) station records used in this study (see "Approach and Methods" section, table 1). The file "bias_corrected_CCSM_output.zip" contains compressed files of bias corrected CCSM3 and CCSM4 output. The file "README.txt" is in the archived directory and provides addition information on file names and formats used.

\section{Appendix 5. R and Python Scripts}

This supplemental section contains links to scripts written in Python Notebook and the R statistical program that were used in data analyses. Data analyses include computation of reference evapotranspiration; calibration, validation, and projections of the transfer functions for peak snowpack and May-July runoff; and Kendall's tau trend analyses.

The file "reference_evapotranspiration.zip" is a compressed set of files that contain two Python Notebook (ipynb) scripts ("ETmon-STNS.ipynb" and "ETmon-CCSM.ipynb") and associated input and output files. The file "README.txt" within the folder further explains the files and data formats. The "ETmon-STNS.ipynb" script reads location information and climate data (air temperature) at input U.S. Historical Climate Network (HCN) and snowpack telemetry (SNOTEL) stations, and computes monthly reference evapotranspiration at station locations. Similarly, the "ETmon-CCSM.ipynb" script computes monthly reference evapotranspiration from CCSM output interpolated to the locations of HCN and SNOTEL stations, and bias corrected. 
The file "peak_snowpack.zip" is a compressed set of files that contain the R script for calibration and application (such as climate projections) of the transfer function for peak snowpack, and input and output files. Within the R script StepF.R, the watershed is selected by the text string "SAKA" to indicate the lower Lake Sakakawea watershed or by "FTPK" to indicate the Fort Peck Lake watershed. The supplied version is for the lower Lake Sakakawea watershed, and the text "SAKA" would need to be replaced by "FTPK" to run the script for the Fort Peck Lake watershed. The compressed file also contains the R script KT.R, which was used to compute significance of temporal trends on the basis of the Kendall's tau test (Kendall, 1938). Input and output files for KT.R also are included in the compressed file. The compressed file contains the R script BP.R which was used to compute the Breusch-Pagan test (Breusch and Pagan, 1979). Input and output files are included in the compressed file. The file "README. $t x t$ " within the folder provides additional information about the files and data formats.

The supplemental file "May-July_runoff.zip" is a compressed set of files that contain the R script for calibration and application (such as climate projections) of the transfer function for May-July runoff, and input and output files. Within this R script StepF.R, the text string "SAKA" indicates the lower Lake Sakakawea watershed, which can be replaced with "FTPK" to indicate the Fort Peck Lake watershed, as similarly described for calibration of the peak snowpack transfer function. The compressed file also contains the R script KT.R, which was used to compute significance of temporal trends on the basis of the Kendall's tau test. Input and output files for KT.R also are included in the compressed file. The compressed file contains the R script $B P . R$, which was used to compute the Breusch-Pagan test. Input and output files for BP.R also are included in the compressed file. The file "README.txt" within the folder provides additional information about the files and data formats.

\section{References Cited}

Breusch, T.S., and Pagan, A.R., 1979, A simple test for heteroscedasticity and random coefficient variation: Econometrica, Journal of the Econometric Society, v. 47, no. 5, p. 1287-1294. [Also available at http://dx.doi.org/10.2307/1911963.]

Kendall, M.G., 1938, A new measure of rank correlation: Biometrika, v. 30, no. 1-2, p. 81-93. [Also available at http://dx.doi.org/10.1093/biomet/30.1-2.81.]

Publishing support provided by: Rolla Publishing Service Center

For more information concerning this publication, contact: Director, USGS South Dakota Water Science Center 1608 Mountain View Road Rapid City, South Dakota 57702 (605) 394-3200

Or visit the South Dakota Water Science Center Web site at: http://sd.water.usgs.gov/ 

